National Water-Quality Assessment Program

\title{
Nitrate Loads and Concentrations in Surface-Water Base Flow and Shallow Groundwater for Selected Basins in the United States, Water Years 1990-2006
}

Scientific Investigations Report 2010-5098 



\section{Nitrate Loads and Concentrations in Surface-Water Base Flow and Shallow Ground water for Selected Basins in the United States, Water Years 1990-2006}

By Norman E. Spahr, Neil M. Dubrovsky, JoAnn M. Gronberg, O. Lehn Franke, and David M. Wolock

National Water-Quality Assessment Program

Scientific Investigations Report 2010-5098 


\title{
U.S. Department of the Interior \\ KEN SALAZAR, Secretary \\ U.S. Geological Survey \\ Marcia K. McNutt, Director
}

\author{
U.S. Geological Survey, Reston, Virginia: 2010
}

For more information on the USGS - the Federal source for science about the Earth, its natural and living resources, natural hazards, and the environment, visit http://www.usgs.gov or call 1-888-ASK-USGS

For an overview of USGS information products, including maps, imagery, and publications, visit http://www.usgs.gov/pubprod

To order this and other USGS information products, visit http://store.usgs.gov

Any use of trade, product, or firm names is for descriptive purposes only and does not imply endorsement by the U.S. Government.

Although this report is in the public domain, permission must be secured from the individual copyright owners to reproduce any copyrighted materials contained within this report.

Suggested citation:

Spahr, N.E., Dubrovsky, N.M., Gronberg, J.M., Franke, O.L., and Wolock, D.M., 2010, Nitrate loads and concentrations in surface-water base flow and shallow groundwater for selected basins in the United States, water years 1990-2006: U.S. Geological Survey Scientific Investigations Report 2010-5098, 39 p. 


\section{Foreword}

The U.S. Geological Survey (USGS) is committed to providing the Nation with reliable scientific information that helps to enhance and protect the overall quality of life and that facilitates effective management of water, biological, energy, and mineral resources (http://Www.usgs.gov/. Information on the Nation's water resources is critical to ensuring long-term availability of water that is safe for drinking and recreation and is suitable for industry, irrigation, and fish and wildlife. Population growth and increasing demands for water make the availability of that water, measured in terms of quantity and quality, even more essential to the long-term sustainability of our communities and ecosystems.

The USGS implemented the National Water-Quality Assessment (NAWQA) Program in 1991 to support national, regional, State, and local information needs and decisions related to water-quality management and policy (http://water.usgs.gov/nawqa). The NAWOA Program is designed to answer: What is the quality of our Nation's streams and groundwater? How are conditions changing over time? How do natural features and human activities affect the quality of streams and groundwater, and where are those effects most pronounced? By combining information on water chemistry, physical characteristics, stream habitat, and aquatic life, the NAWQA Program aims to provide science-based insights for current and emerging water issues and priorities. From 1991 to 2001, the NAWQA Program completed interdisciplinary assessments and established a baseline understanding of water-quality conditions in 51 of the Nation's river basins and aquifers, referred to as Study Units (http://water.usgs.gov/nawqa/studyu.htm/.

National and regional assessments are ongoing in the second decade (2001-2012) of the NAWQA Program as 42 of the 51 Study Units are selectively reassessed. These assessments extend the findings in the Study Units by determining water-quality status and trends at sites that have been consistently monitored for more than a decade, and filling critical gaps in characterizing the quality of surface water and groundwater. For example, increased emphasis has been placed on assessing the quality of source water and finished water associated with many of the Nation's largest community water systems. During the second decade, NAWQA is addressing five national priority topics that build an understanding of how natural features and human activities affect water quality, and establish links between sources of contaminants, the transport of those contaminants through the hydrologic system, and the potential effects of contaminants on humans and aquatic ecosystems. Included are studies on the fate of agricultural chemicals, effects of urbanization on stream ecosystems, bioaccumulation of mercury in stream ecosystems, effects of nutrient enrichment on aquatic ecosystems, and transport of contaminants to public-supply wells. In addition, national syntheses of information on pesticides, volatile organic compounds (VOCs), nutrients, trace elements, and aquatic ecology are continuing.

The USGS aims to disseminate credible, timely, and relevant science information to address practical and effective water-resource management and strategies that protect and restore water quality. We hope this NAWQA publication will provide you with insights and information to meet your needs, and will foster increased citizen awareness and involvement in the protection and restoration of our Nation's waters. 
The USGS recognizes that a national assessment by a single program cannot address all waterresource issues of interest. External coordination at all levels is critical for cost-effective management, regulation, and conservation of our Nation's water resources. The NAWQA Program, therefore, depends on advice and information from other agencies-Federal, State, regional, interstate, Tribal, and local — as well as nongovernmental organizations, industry, academia, and other stakeholder groups. Your assistance and suggestions are greatly appreciated.

Matthew C. Larsen

Associate Director for Water 


\section{Contents}

Abstract
Introduction
Site Selection, Data, and Methods
Base flow.
Sitrate Loads
Shallow Groundwater Nitrate Concentrations
Base-Flow Index
Base-Flow Nitrate Loads
Reographic Distribution of Nitrate Load Ratios Concentrations in Surface-Water Base Flow and Shallow Groundwater
$\quad$ Nitrate Concentrations in Surface-Water Base Flow
Comparison of Nitrate Concentrations in Surface-Water Base Flow and Shallow
Groundwater

\section{Figures}

1. Map showing base-flow index for selected National Water-Quality Assessment

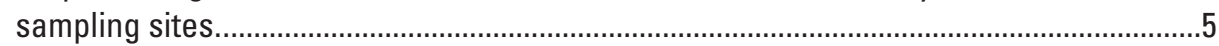

2. Map showing distribution of base-flow index by hydrologic landscape regions.............6

3. Map showing distribution of base-flow index by categories of hydrologic

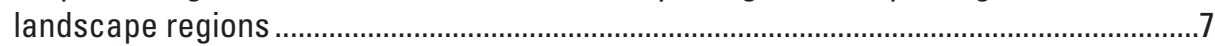

4. Map showing percentage of total nitrate load contributed by base flow (nitrate load ratio) for selected National Water-Quality Assessment sampling sites...

5-9. Graphs showing relation of:

5. Nitrate concentration to streamflow for Clear Creek near Sanger in the Trinity River Basin, Texas, water years1993-2005.

6. Streamflow and nitrate concentration to time for Sugar Creek at New Palestine, Indiana (modified from Fenelon, 1998), and (B) nitrate concentration and streamflow for the same time period

7. Nitrate concentration and streamflow for Tulpehocken Creek near Bernville, Pennsylvania, where 78 percent of the nitrate load is contributed by base flow, water years 1999-2001

8. Nitrate concentration and streamflow for Soda Butte Creek near Silvergate, Montana, a typical snowmelt-runoff site, water years 1999-2001................11

9. Nitrate concentration and streamflow for two sites where streamflow and nitrate load are almost entirely contributed by groundwater discharge 
10. Map showing distribution of nitrate load percentage by hydrologic landscape categories

11. Map showing spatial distribution of mean annual base-flow nitrate concentrations....15

12-14. Graphs showing:

12. Distribution of surface-water base-flow nitrate concentrations by land-use category

13. Comparison of nitrate concentrations in base flow and shallow groundwater for selected National Water-Quality Assessment sampling sites

14. Relation of concentration to base-flow index corresponding to the date of sampling for selected National Water-Quality Assessment sampling sites.

\section{Tables}

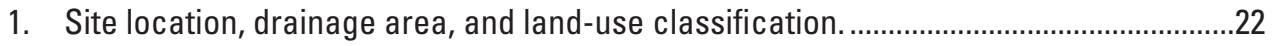

2. Comparison of longer-term base-flow index to load-simulation period base-flow

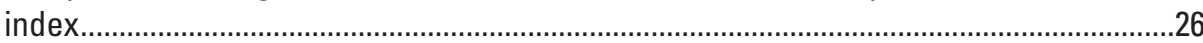

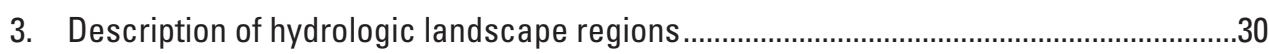

4. Nitrate load ratios and hydrologic landscape regions ......................................................

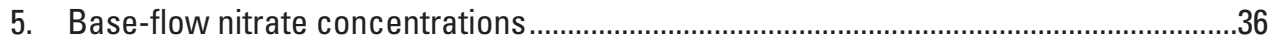

6. Base-flow nitrate concentration and associated land-use study network median nitrate concentration 


\section{Conversion Factors}

\begin{tabular}{lll}
\hline Multiply & By & To obtain \\
\hline mile $(\mathrm{mi})$ & 1.609 & kilometer $(\mathrm{km})$ \\
foot $(\mathrm{ft})$ & 0.3048 & meter $(\mathrm{m})$ \\
square mile $\left(\mathrm{mi}^{2}\right)$ & 2.590 & square kilometer $\left(\mathrm{km}^{2}\right)$ \\
cubic foot per second $\left(\mathrm{ft}^{3} / \mathrm{s}\right)$ & 0.02832 & cubic meter per second $\left(\mathrm{m}^{3} / \mathrm{s}\right)$ \\
\hline
\end{tabular}

\section{Abbreviations Used in Report}

\begin{tabular}{ll}
\hline Abbreviation & Description \\
\hline AMLE & Adjusted maximum-likelihood estimation \\
MLE & Maximum likelihood estimation \\
mg/L & Milligrams per liter \\
NAWQA & National water-quality assessment \\
USGS & United States Geological Survey \\
BFI & Base-flow index \\
GIS & Geographic information system \\
LOADEST & Load estimator \\
LOWESS & Locally weighted scatterplot smooth \\
\hline
\end{tabular}

Latitude and longitude are referenced to the North American Datum of 1983 (NAD83).

Altitude, as used in this report, refers to distance above the North American Vertical Datum of 1988 (NAVD88).

Water year is the continuous 12-month period, October 1 through September 30. The water year is designated by the calendar year in which it ends and which includes 9 of the 12 months. Thus, the year ending September 30, 1980, is referred to as water year 1980. 



\title{
Nitrate Loads and Concentrations in Surface-Water Base Flow and Shallow Groundwater for Selected Basins in the United States, Water Years 1990-2006
}

\author{
By Norman E. Spahr, Neil M. Dubrovsky, JoAnn M. Gronberg, 0. Lehn Franke, and David M. Wolock
}

\section{Abstract}

Hydrograph separation was used to determine the baseflow component of streamflow for 148 sites sampled as part of the National Water-Quality Assessment program. Sites in the Southwest and the Northwest tend to have base-flow index values greater than 0.5 . Sites in the Midwest and the eastern portion of the Southern Plains generally have values less than 0.5 . Base-flow index values for sites in the Southeast and Northeast are mixed with values less than and greater than 0.5 . Hypothesized flow paths based on relative scaling of soil and bedrock permeability explain some of the differences found in base-flow index. Sites in areas with impermeable soils and bedrock (areas where overland flow may be the primary hydrologic flow path) tend to have lower base-flow index values than sites in areas with either permeable bedrock or permeable soils (areas where deep groundwater flow paths or shallow groundwater flow paths may occur).

The percentage of nitrate load contributed by base flow was determined using total flow and base flow nitrate load models. These regression-based models were calibrated using available nitrate samples and total streamflow or base-flow nitrate samples and the base-flow component of total streamflow.

Many streams in the country have a large proportion of nitrate load contributed by base flow: 40 percent of sites have more than 50 percent of the total nitrate load contributed by base flow. Sites in the Midwest and eastern portion of the Southern Plains generally have less than 50 percent of the total nitrate load contributed by base flow. Sites in the Northern Plains and Northwest have nitrate load ratios that generally are greater than 50 percent. Nitrate load ratios for sites in the Southeast and Northeast are mixed with values less than and greater than 50 percent.

Significantly lower contributions of nitrate from base flow were found at sites in areas with impermeable soils and impermeable bedrock. These areas could be most responsive to nutrient management practices designed to reduce nutrient transport to streams by runoff. Conversely, sites with potential for shallow or deep groundwater contribution (some combination of permeable soils or permeable bedrock) had significantly greater contributions of nitrate from base flow. Effective nutrient management strategies would consider groundwater nitrate contributions in these areas.

Mean annual base-flow nitrate concentrations were compared to shallow-groundwater nitrate concentrations for 27 sites. Concentrations in groundwater tended to be greater than base-flow concentrations for this group of sites. Sites where groundwater concentrations were much greater than baseflow concentrations were found in areas of high infiltration and oxic groundwater conditions. The lack of correspondingly high concentrations in the base flow of the paired surface-water sites may have multiple causes. In some settings, there has not been sufficient time for enough high-nitrate shallow groundwater to migrate to the nearby stream. In these cases, the stream nitrate concentrations lag behind those in the shallow groundwater, and concentrations may increase in the future as more high-nitrate groundwater reaches the stream. Alternatively, some of these sites may have processes that rapidly remove nitrate as water moves from the aquifer into the stream channel.

Partitioning streamflow and nitrate load between the quick-flow and base-flow portions of the hydrograph coupled with relative scales of soil permeability can infer the importance of surface water compared to groundwater nitrate sources. Study of the relation of nitrate concentrations to base-flow index and the comparison of groundwater nitrate concentrations to stream nitrate concentrations during times when base-flow index is high can provide evidence of potential nitrate transport mechanisms. Accounting for the surface-water and groundwater contributions of nitrate is crucial to effective management and remediation of nutrient enrichment in streams.

\section{Introduction}

Knowledge of the relative sources of streamflow is important because the concentration of nutrients is often different among the various sources and determining the source of nutrient loads is critical to the development of nutrient management strategies. The amount of water flowing in a stream (streamflow) is a complex result of climatic, physiographic, surface water, groundwater, and human-induced processes. 
At any given point along a stream, the source of the water can include precipitation, surface runoff, groundwater discharge, interflow (that is, shallow subsurface flow), release from watershed storages (bank storage, wetlands, lakes), and human sources (reservoirs, point discharges, return flows) each with its own chemical signature. The change in streamflow and stream chemistry over time will reflect the cumulative effects of all of these factors.

Streamflow can be partitioned into two general classes of flow: quick flow, which consists of surface runoff and rapid interflow; and base flow, which consists of groundwater discharge, release from other watershed storages, and longerterm interflow (Maidment, 1993). Base flow traditionally has been attributed in large part to groundwater discharge, but it is important to note that groundwater may be only one component of base flow.

The term base flow also can refer to lower flow periods of an annual hydrograph. Nutrient conditions during these critical low-flow periods are important to the ecological health of streams and rivers. In this report, base flow refers to the portion of streamflow that has been partitioned or separated from the quick-flow component.

This report expands on the national synthesis of nutrient data collected as part of the U.S. Geological Survey (USGS) National Water-Quality Assessment (NAWQA) program. Mueller and Spahr (2006) describe nutrient-data collection, processing, and analysis as well as annual nutrient conditions for a group of surface-water sites that the NAWQA program refers to as the "basic fixed sites." This report describes nitrate loads and concentrations in surface-water base flow and shallow groundwater for selected basins upstream from basic fixed sites. Methods used to characterize the base-flow component of streamflow and nitrate load for a subset of sites in the basic fixed site network are described. The spatial distributions of nitrate load contributed by base flow and the concentration of nitrate for base-flow conditions are described at national and regional scales. Where groundwater nitrate concentrations are available, a comparison of base-flow nitrate concentration to shallow groundwater concentration is presented. The period of data collection varies between groups of NAWQA sites. This analysis uses available streamflow and nitrate data collected during water years 1990-2006.

\section{Site Selection, Data, and Methods}

NAWQA stream sites within the conterminous United States having drainage-basin areas less than 500 square miles were selected as the initial group of sites for analysis. Annual streamflow hydrographs for each site were screened for issues that may affect base-flow separation such as obvious flow regulation or tidal influences. Station and basin comments provided by NAWQA study unit personnel also were reviewed to determine suitability of sites for base-flow analysis. Based on these comments, sites with potential effect from wastewater treatment facilities or impoundments were excluded from analysis. Insufficient streamflow or nitrate data excluded additional sites resulting in 148 sites available for investigation (site names and numbers, and location information are listed in table 1 in the Supplemental Information section of this report). Streamflow and nitrate concentration data presented by Mueller and Spahr (2005) were updated for the selected sites with data from the USGS National Water Information System (accessed at http://waterdata.usgs.gov/usa/nwis/) to include any additional data for water years 1990-2006. Sites were classified by the percentage of major land use within the upstream basin according to the following criteria:

- Agricultural: greater than 50 percent agricultural land and less than or equal to 5 percent urban land;

- Urban: greater than 25 percent urban land and less than or equal to 25 percent agricultural land;

- Undeveloped: less than or equal to 5 percent urban land and less than or equal to 25 percent agricultural land;

- Mixed: All other combinations of urban, agricultural, and undeveloped land.

\section{Base Flow}

Hydrograph separation was used to determine the baseflow component of streamflow for the 148 sites. Several computer-based methods are available to estimate the baseflow component from daily streamflow records (Rutledge, 1998; Sloto and Crouse, 1996; Arnold and others, 1995; Wahl and Wahl, 1988). The base-flow index (BFI) computer program (Wahl and Wahl, 1988) (http://www.usbr.gov/pmts/ hydraulics_lab/twahl/bfi/index.html, accessed July 2007), a hydrograph separation technique and one of the base-flow estimation programs developed by the USGS, was selected for use in this study. The BFI routine is based on a method developed by the Institute of Hydrology, United Kingdom (1980) and has been applied in a variety of hydrologic studies (for example, see Winter and others (1998); Garg and others, 2003; Tesoriero and others, 2009). The BFI program computes estimates of daily base flow and an average annual base-flow index (the ratio of base flow to total streamflow).

Halford and Mayer (2000) give a critical review of the use of hydrograph separation techniques for determining groundwater discharge and recharge. Issues regarding hydrograph separation identified by Halford and Mayer include the inability of hydrograph separation techniques to distinguish between groundwater discharge and water discharged from bank storage, wetlands, and surface-water bodies. Suggested alternative methods include the use of geochemical tracers and groundwater-flow models. Because of the broad geographic extent of the present study, however, hydrograph separation is the only viable option. Base-flow results presented in this report may not be entirely generated by groundwater discharge. It is also important to note that even in areas where groundwater discharge is important, streams are not always 
gaining and preferential flow paths as well as exchange of water in the hyporheic zone are important processes.

Daily streamflow data sets with complete water-year records were used as input to the BFI routine. The routine generates daily base-flow values for each day of the input data set. The base-flow index (annual base flow divided by annual total flow) was computed for each complete water year of data for each site. The number of years of streamflow data often exceeded the number of years of nitrate data and load estimates. Average base-flow index values were computed using available streamflow data for the 1990-2006 period as well as for the nitrate load estimation period, but it was found that the average base-flow index estimates did not change significantly when different periods were analyzed (data available in table 2 in the Supplemental Information Section of this report). Therefore, only the BFI values for the nitrate load estimation period were used in subsequent analyses. Neff and others (2005, p. 6) also note the stability of base-flow index values.

\section{Nitrate Loads}

Base flow and total flow nitrate loads were determined using multiple-regression analysis as implemented in the computer program LOADEST (Runkel and others, 2004). The dependent variable in each case was the natural logarithm of nitrate load, computed as the product of a measured concentration and the mean daily streamflow (or mean daily base flow) for the date of sample collection. Nitrate samples collected at the sites were classified as either base-flow or non-base-flow samples: a base-flow sample was one that was collected on any day when the base flow was 77 percent or more of the total flow (Langland and others, 1995). All nitrate samples were used to calibrate the total flow models, whereas only base-flow samples were used to calibrate the base-flow load models.

The explanatory (independent) variables for each model were selected from a set of potential predictor variables:

- natural logarithm of streamflow, log (flow)

- $\log$ (flow) squared

- time, in decimal years

- sine of time

- cosine of time

- time squared

Models were fit using all possible combinations of these variables, and the best model was selected on the basis of the Akaike Information Criteria (Akaike, 1981). The sine and cosine terms, which account for seasonality, were always included together if either was selected.

Because nitrate concentrations included censored values (values reported as less than the laboratory reporting level), regression coefficients were determined by an adjusted maximum-likelihood estimation (AMLE) method (Cohn and others, 1992). The AMLE method corrects for bias in the standard maximum-likelihood (MLE) regression coefficients and also incorporates a factor that minimizes the bias that can occur when estimated logarithms of constituent load are retransformed to original units.

The calibrated models along with daily streamflows and base flows at each site were used to estimate daily total nitrate loads and daily base-flow nitrate loads for available water years. Mean annual total loads and mean annual base-flow loads were then computed from the daily values. The period of record for load simulation varied from 1 to 16 years with an average of 6 years. The proportion of nitrate load contributed by base flow was determined from the ratio of base-flow load to total flow load. Flow-weighted mean nitrate concentrations in milligrams per liter $(\mathrm{mg} / \mathrm{L})$ for total flow and base flow were calculated by dividing the total load over the estimation time period by the total streamflow and the total base-flow load by the total base flow. This general method of streamflow and load partitioning has been used in other studies (Jordan and others, 1997; Bachman and others, 1998; Mullaney, 2007).

\section{Shallow Groundwater Nitrate Concentrations}

The NAWQA program assessed nutrients in groundwater within specific land-use settings. Land-use studies focused on shallow groundwater primarily within agricultural, urban, or undeveloped settings. Each study involved the sampling of about 20 to 30 randomly located wells within each targeted land-use area. To identify surface-water sites suitable for comparison to groundwater data, groundwater network locations were intersected with the basin upstream from the selected surface-water sampling sites using geographic information system (GIS) tools. Groundwater networks that intersected one of the 148 drainage basins and had a similar land-use classification were selected for comparison. A single nitrate sample from each well was used to calculate the network median nitrate concentration.

\section{Statistical Analysis}

Nonparametric statistical methods were chosen to test for differences among categories of base-flow index, load ratios, and concentrations. Differences among all categories were tested by using analysis of variance on the ranks of the data (Conover and Iman, 1981). If a significant difference was indicated by this test, differences between categories were evaluated by applying Tukey's multiple-comparison test (Helsel and Hirsch, 1992, p. 196) to the rank-transformed data. The multiple comparison test results are shown in conjunction with box plots displaying the distributions of the values. Box plots identified by the same letter indicate that the distributions are not significantly different. An alpha value of 0.05 was used to evaluate the significance of the test. If two letters are listed (for example, AB), the distribution is not significantly different from other distributions identified by either one of those letters. 
Spearman's rho, a rank correlation coefficient, (Helsel and Hirsch, 1992, p. 217) was used as a measure of the significance of the relation between variables. A significant result indicates that rho is different from 0 at an alpha level of 0.05 . In some graphical comparisons among variables a smooth line is used to depict the general shape of the relation. Locally weighted scatterplot (LOWESS) smoothing method (Helsel and Hirsch, 1992, p. 288) was used to generate the line.

\section{Base-Flow Index}

The base-flow index calculated for the 148 streams ranges from 0.04 to 0.98 with a median of 0.48 , and values showed distinctive spatial distributions (fig. 1). Sites in the Southwest and the Northwest tend to have base-flow index values greater than 0.5. Sites in the Midwest and the eastern portion of the Southern Plains generally have values less than 0.5. Base-flow index values for sites in the Southeast and Northeast are mixed with values less than and greater than 0.5 . The geographic distribution generally corresponds to a national map of base-flow index produced by Santhi and others (2008) using hydrograph separation based on a recursive digital filter and streamflow data from more than 8,600 streamflow-gaging stations. Exceptions include sites in Minnesota and parts of Georgia where Santhi and others estimated values greater than 0.5 , whereas data for this report indicate values less than 0.5 .

Climate, hydrogeology, and physiography contribute to differences in base-flow index. The hydrologic landscapes concept (Winter, 2001) can be used to understand some aspects of the geographic pattern in base-flow index values. Using GIS and statistical tools, Wolock and others (2004) generated hydrologic landscape regions for the conterminous United States at both 1-kilometer and 100-meter resolutions (D.M. Wolock and N. Nakagaki, U.S. Geological Survey, written commun., 2008; Wolock, 2003). The 20 hydrologic landscape regions (table 3, Supplemental Information Section of this report) are based on landscape and climatic characteristics that are assumed to affect hydrologic processes. Hydrologic landscape regions are not contiguous and the same region can occur in different parts of the country. The dominant hydrologic landscape region, mapped at the 100-meter resolution scale, was determined for the basin upstream from each site. The distribution of base-flow index values for sites in each hydrologic landscape region is shown in figure 2. Individual values rather than box plots are shown for regions that have 6 or fewer sites. Multiple comparison tests were not evaluated for base-flow index among the hydrologic landscapes due to the highly variable, and often low, number of sites. However, differences in base-flow index values are apparent for some regions. Region 2, which has permeable soils and bedrock, has greater values than regions such as region 6, which have impermeable soils and bedrock. Basin relief is one of the land-surface form characteristics used in the generation of hydrologic landscape regions (Wolock and others, 2004). Santhi and others (2008) show good correspondence between basin relief and baseflow index values and this is apparent in figure 2. Hydrologic landscape regions 15 - 20 represent mountainous areas. Sites located in landscapes 15 and 20 have somewhat greater median base-flow index values than sites found in the other landscape regions (fig. 2).

The 20 hydrologic landscapes were classified into four groups based on relative scaling of soil and bedrock permeability by Wolock and others (2004), to examine hydrologic processes and potential flow paths. This classification of relative bedrock permeability is based on lithologic groups of principal aquifers and bedrock permeability classes. Areas with no principal bedrock aquifer were assigned the lowest permeability class (Wolock and others, 2004).

This classification did not consider all of the shallow aquifers of glacial origin in the northern United States. This classification represents hypothetical flow paths; overland flow in areas of impermeable soils, shallow groundwater flow in areas of permeable soils, and deeper groundwater flow in areas with permeable bedrock. Santhi and others (2008) used a national base-flow index grid to determine mean base flow for each of the 20 hydrologic landscapes regions. They compared the hydrologic response in each hydrologic landscape region to the hypothesized response for each region based on relative scaling of soil and bedrock permeability developed by Wolock and others (2004). They concluded that the hypothesized hydrologic response was reasonable for large-scale analysis but further refinement of hydrologic landscape regions may be required for local scale study.

Each site was classified using these relative permeability categories and the distribution of sites within the four categories as well as the distribution of base-flow index values within each category is shown in figure 3. Although there is significant variability, sites in areas with impermeable soils and bedrock (areas where overland flow may be the primary hydrologic flow path) tend to have lower base-flow index values than sites in areas with either permeable bedrock or permeable soils (areas where deep groundwater flow paths or shallow groundwater flow paths may occur, the second and third categories in figure 3). Within this data set, the relative rankings of bedrock and soil permeability do not differentiate the base-flow index for areas with potential deep groundwater flow from areas with potential shallow groundwater flow (the second and third categories in figure 3 ). The fourth category in figure 3, representing sites with potential for both shallow and deep groundwater flow paths, are not statistically different from any of the other categories. Additional basin characteristics, such as relief, refinement of permeability categories, and a much greater number of sites may be needed to further categorize the base-flow generation processes. However, areas with impermeable soils and bedrock are areas where overland flow could be the primary hydrologic flow path and groundwater/surface-water interactions may be limited. 


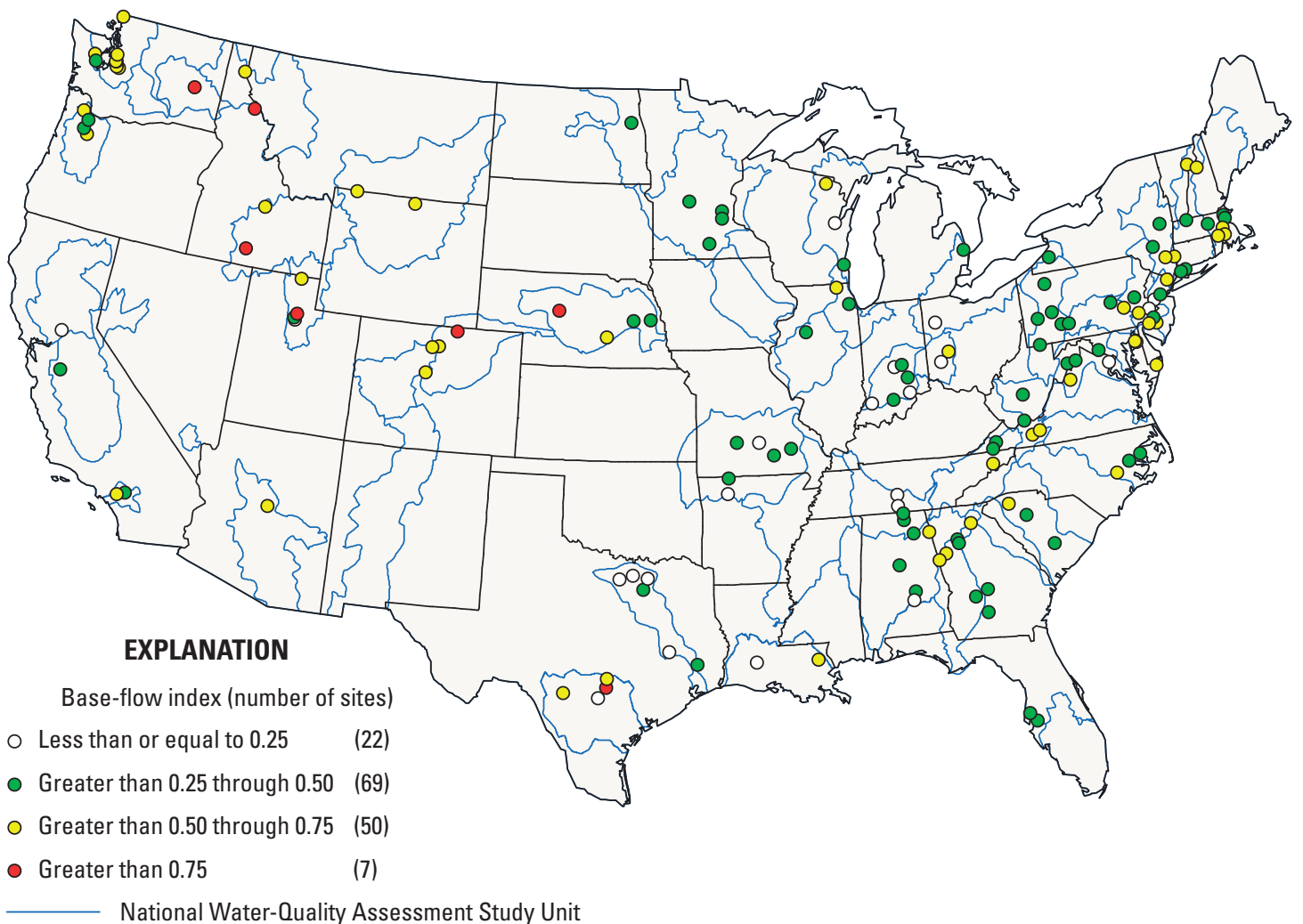

National Water-Quality Assessment Study Unit

Geographic framework used in text

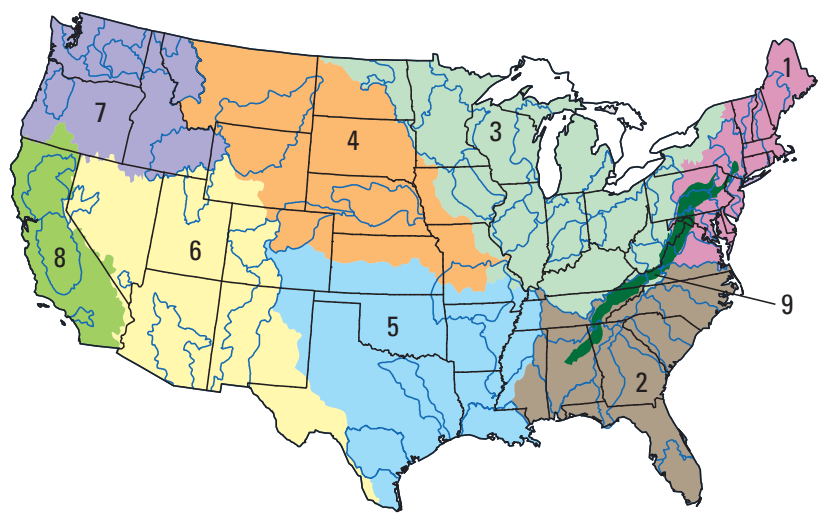

1-Northeast (New England and Mid-Atlantic Water-Resources Regions)

2-Southeast (South Atlantic-Gulf and Tennessee Water-Resources Regions)

3-Midwest (Great Lakes, Ohio, Upper Mississippi, and Souris-Red-Rainy Water-Resources Regions)

4-Northern Plains (Missouri Water-Resources Region)

5-Southern Plains (Lower Mississippi, Arkansas-White-Red, and Texas-Gulf Water-Resources Regions)

6-Southwest (Rio Grande, Upper Colorado, Lower Colorado, and Great Basin Water-Resources Regions)

7-Northwest (Pacific Northwest Water-Resources Region)

8-California (California Water-Resources Region)

9-Valley and Ridge

Figure 1. Base-flow index for selected National Water-Quality Assessment sampling sites. 

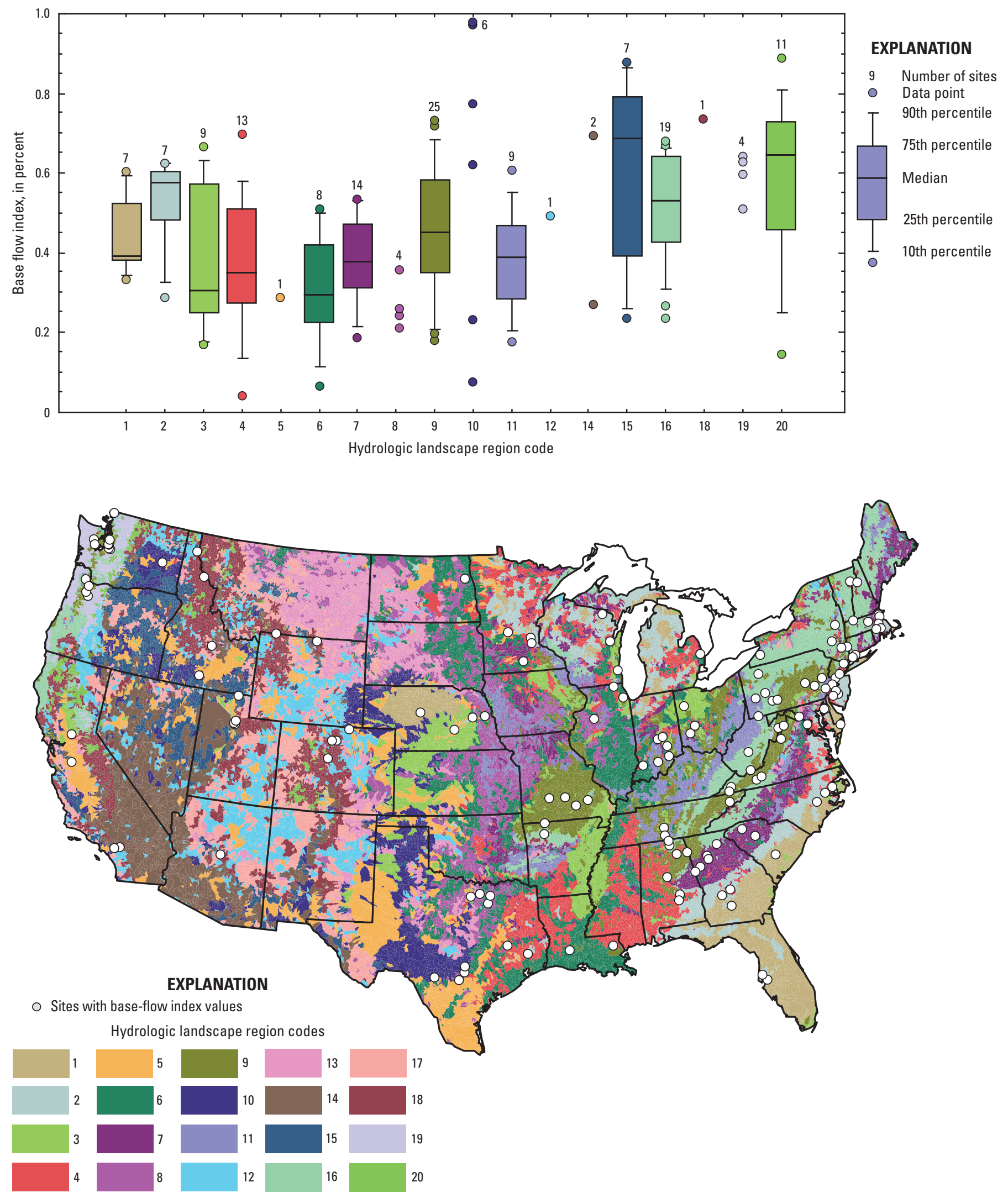

Figure 2. Distribution of base-flow index by hydrologic landscape regions. 

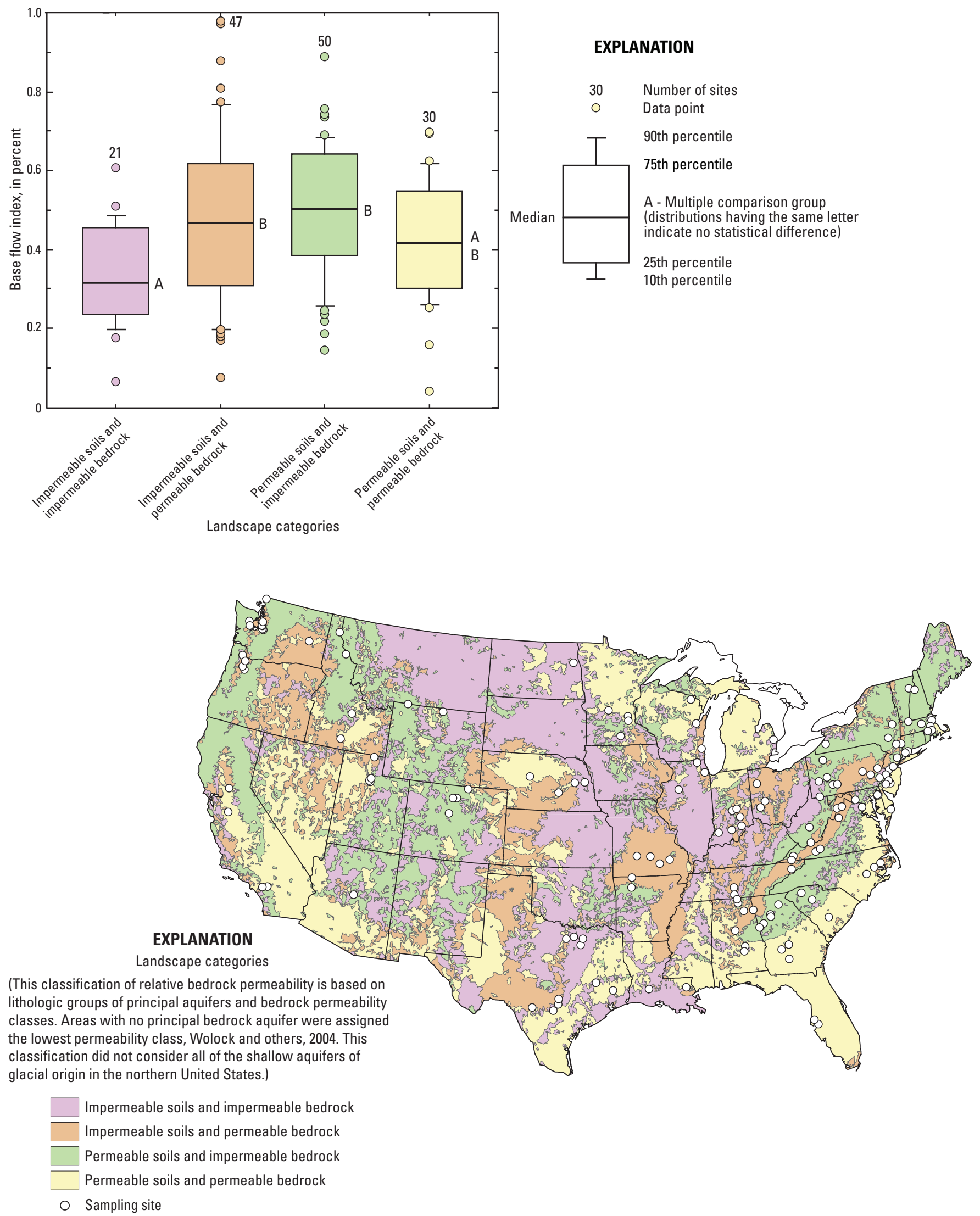

Figure 3. Distribution of base-flow index by categories of hydrologic landscape regions. 


\section{Base-Flow Nitrate Loads}

The proportion of nitrate load contributed by base flow, determined as the ratio of base-flow load to total flow load multiplied by 100, ranged from about 3 to 98 percent with a median of 44 percent (nitrate load ratio data are listed in table 4 in the Supplemental Information Section of this report). The distribution of nitrate load ratios can be described spatially, and hydrologic landscape regions provide a framework to assess the observed patterns.

\section{Geographic Distribution of Nitrate Load Ratios}

Many streams in the country have a large proportion of nitrate load contributed by base flow: 40 percent of the sites have more than 50 percent of the total nitrate load contributed by base flow (fig. 4). Sites in the Midwest and eastern portion of the Southern Plains generally have less than 50 percent of the total nitrate load contributed by base flow (fig. 4). Sites in the Northern Plains and Northwest have nitrate load ratios that generally are greater than 50 percent. Nitrate load ratios for sites in the Southeast and Northeast are mixed with values less than and greater than 50 percent. Although broad regional patterns are somewhat evident, smaller cluster of sites are distinct where similar processes result in similar proportions.

Sites in the Trinity River Basin of eastern Texas typically have less than 25 percent of their nitrate load contributed by base flow (fig. 4). The low base-flow proportion at these sites results from periods of extremely low flow with low nitrate concentrations followed by short duration runoff events with greater nitrate concentrations (Land and others, 1998). The concentration discharge relation for Clear Creek (a site in the Trinity River Basin), for example, shows greater nitrate concentrations during high flows and relatively low concentrations during base-flow periods (fig. 5) Base-flow contribution to the nitrate load for Clear Creek is less than 10 percent.

Sites in the eastern portion of the Midwest (Indiana and Ohio) also have low base-flow nitrate load ratios. Five of the nine sites in Indiana and Ohio have base-flow nitrate load ratios less that 25 percent (fig. 4). Base-flow index values for these sites also are low, less than 32 percent. The relatively low contributions of groundwater to in-stream nitrate loads can result from the use of tile drains, a common agricultural practice in much of the Midwest. Fenelon (1998) describes the higher nitrate concentrations found in streams when tile drains are flowing as a result of the drainage system intercepting nitrate-rich shallow groundwater (fig. 6). The shortened flow paths, created by drainage systems, result in much of this water being proportioned into the quick-flow component during hydrograph separation. When tile drains go dry, stream nitrate concentrations in Sugar Creek reflect the typically low concentrations found in deeper aquifers contributing to base flow (Fenelon, 1998).
Seven sites located in the Valley and Ridge physiographic province running from northern Alabama through Tennessee, Virginia, Maryland, and Pennsylvania have more than 50 percent of the nitrate load contributed by base flow (fig. 4). Base-flow nitrate contribution is more than 70 percent for 4 of these sites, which are underlain by the Valley and Ridge carbonate aquifers. Although characteristics vary within the Valley and Ridge carbonate aquifers, they generally are considered unconfined with karst features including sinkholes, springs, and caverns (Lindsey and others, 2009). The karst and solution features result in aquifers that are susceptible to contamination (Hampson and others, 2000) as well as extensive interaction between groundwater and surface water. The site on Tulpehocken Creek, located in an agricultural area of eastern Pennsylvania (the northern most of the indicated Valley and Ridge sites on figure 4, part of the Delaware River Basin), has 78 percent of the nitrate load contributed by base flow, as well as, a high base-flow index of 0.73 . Nitrate concentrations are relatively high and invariant at low and moderate flows, and decrease during high-flow conditions (fig. 7).

Many sites with snowmelt-dominated hydrology (such as Tongue River, Soda Butte Creek, and Big Thompson River) have base-flow nitrate load ratios greater than 50 percent (fig. 4). Nitrate concentrations at these sites typically are low (tenths of milligrams per liter) but are at least twice as large at low flow, during the non snowmelt-runoff period, than during moderate- and high-flow periods (fig. 8). The higher concentrations during base-flow periods coupled with base-flow index values greater than 50 percent results in high base-flow load percentages.

Areas where streamflow is derived principally from groundwater have a large proportion of the nitrate load contributed by base flow. The Sandhills region of central Nebraska, represented by the Dismal River (fig. 4), is an area with where little runoff occurs because nearly all of the precipitation infiltrates directly to groundwater (Frenzel and others, 1998). Streamflow is almost entirely generated by groundwater discharge resulting in a base-flow nitrate load contribution of about 98 percent. Nitrate concentrations have little variation with changes in streamflow at the Dismal River site (fig. 9). Streamflow in the Comal River, in south central Texas, primarily is from Comal Springs which discharges from the Edwards aquifer (Ging and Otero, 2003). The base-flow nitrate load ratio about 98 percent, and the relation between concentration and streamflow is also relatively invariant (fig. 9). 


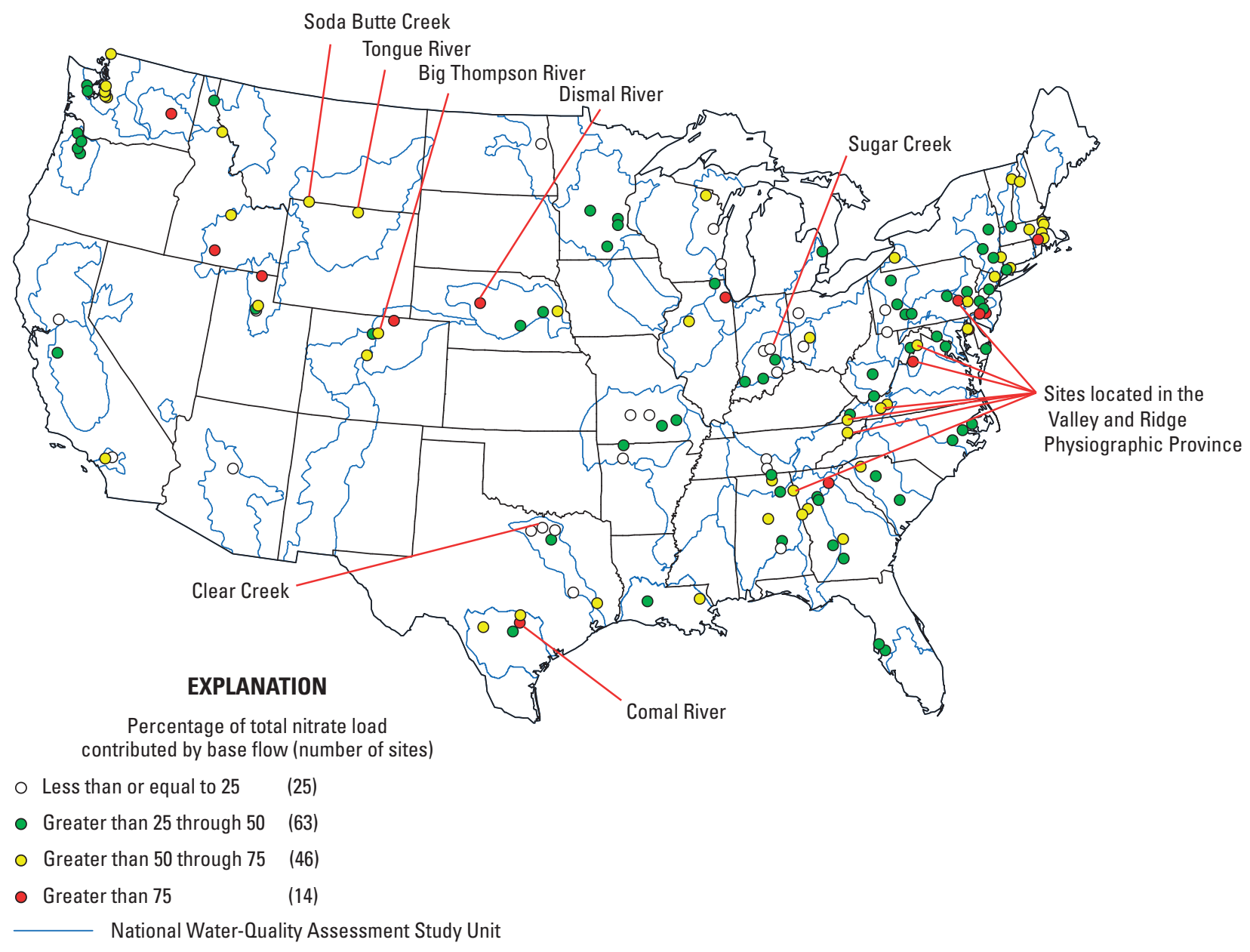

Figure 4. Percentage of total nitrate load contributed by base flow (nitrate load ratio) for selected National Water-Quality Assessment sampling sites.

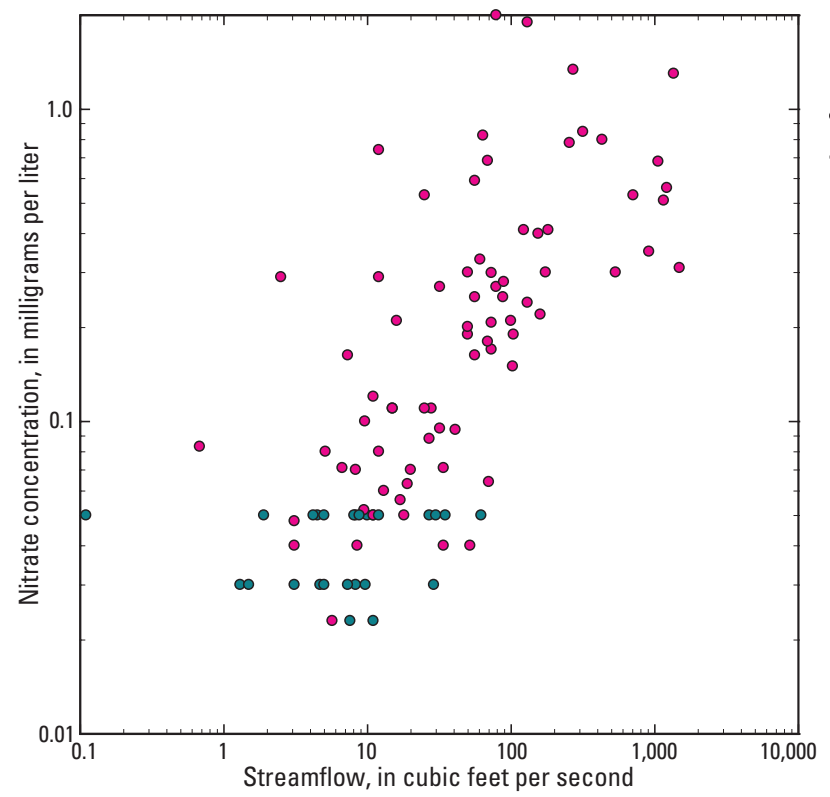

EXPLANATION
- Nitrate sample
- Concentration less than
laboratory reporting level
(Reporting levels varied during
the sampling period for this site)

Figure 5. Relation of nitrate concentration to streamflow for Clear Creek near Sanger in the Trinity River Basin, Texas, water years 1993-2005. 

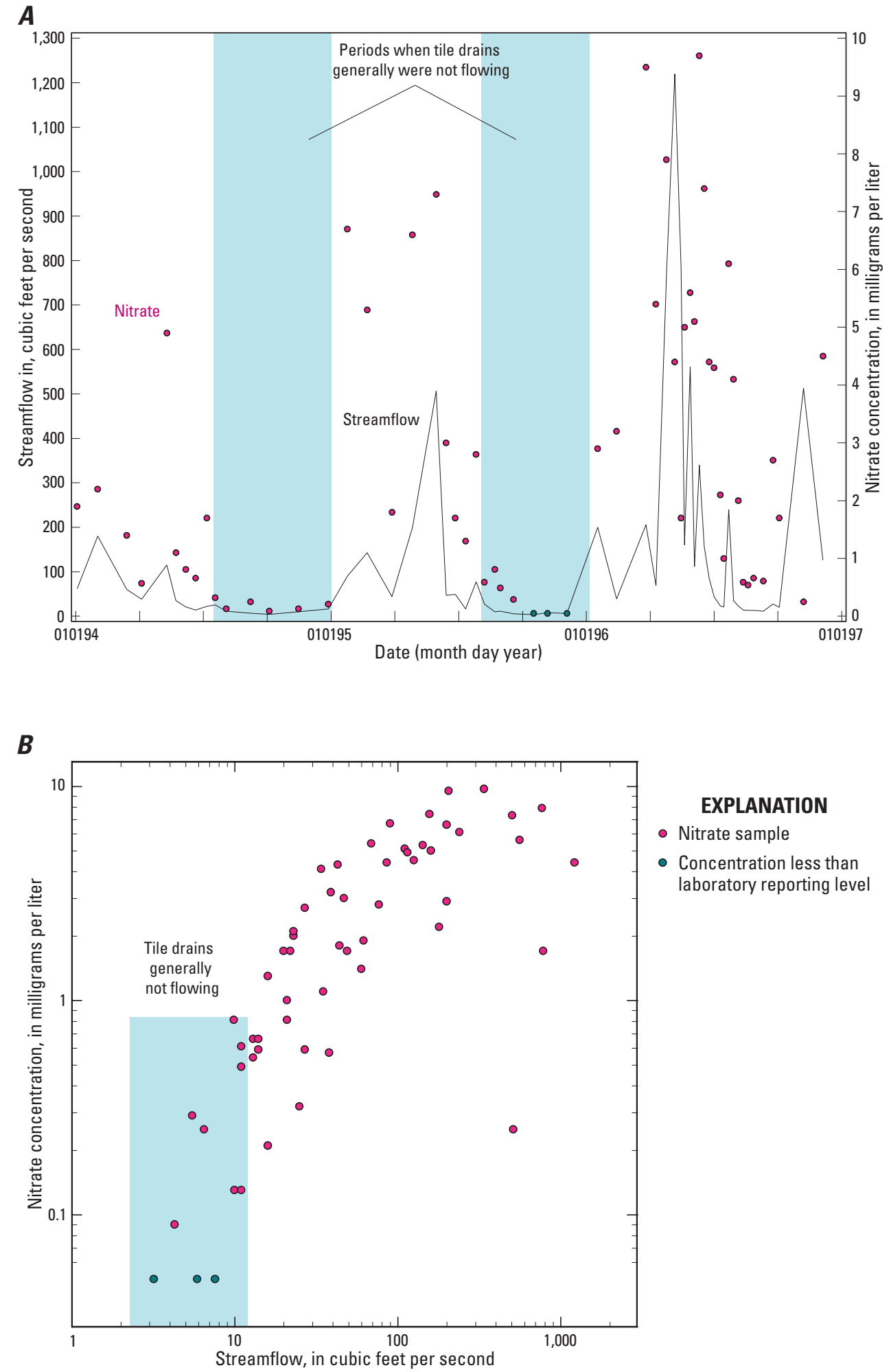

Figure 6. The relation of $(A)$ streamflow and nitrate concentration to time for Sugar Creek at New Palestine, Indiana (modified from Fenelon, 1998), and (B) nitrate concentration and streamflow for the same time period. 


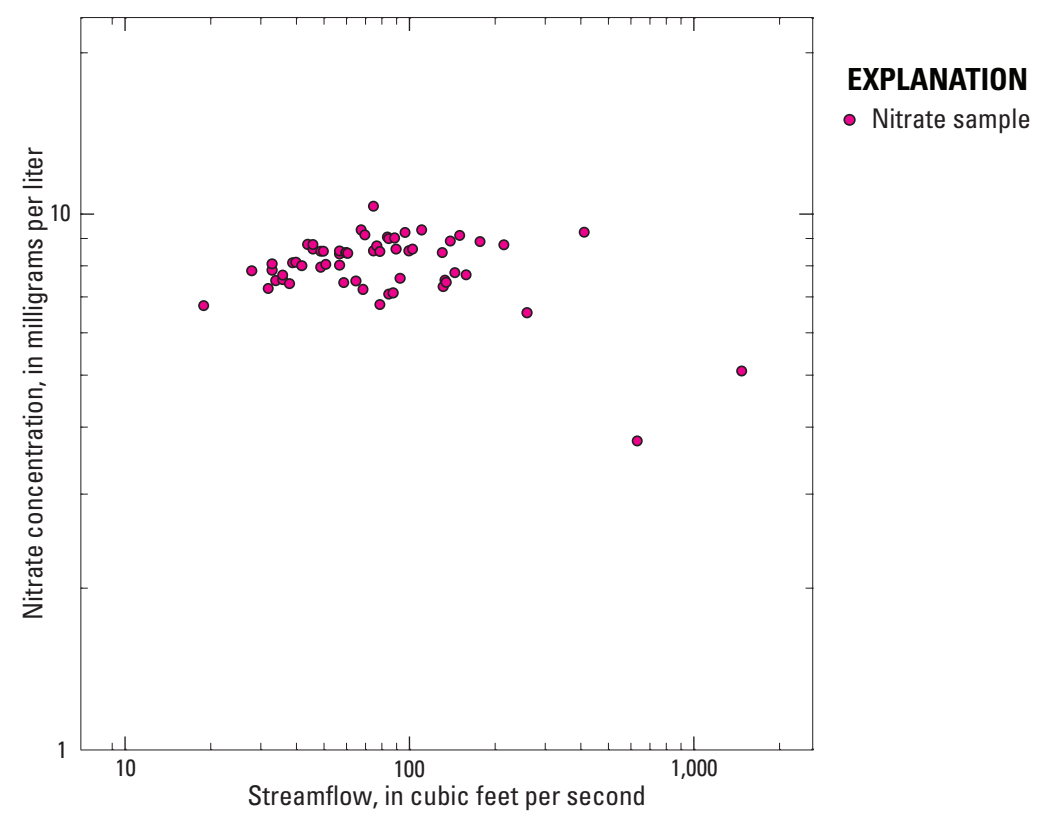

Figure 7. Relation of nitrate concentration and streamflow for Tulpehocken Creek near Bernville, Pennsylvania, where 78 percent of the nitrate load is contributed by base flow, water years 1999-2001.

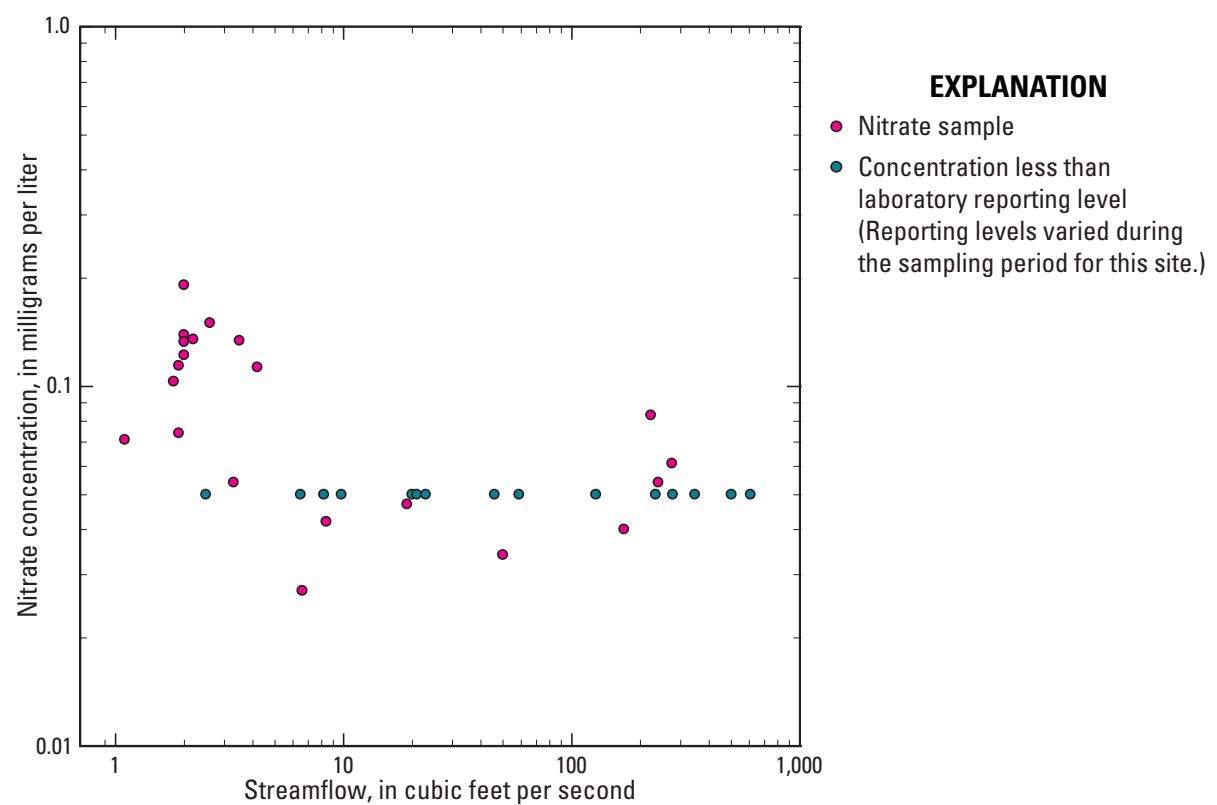

Figure 8. Relation of nitrate concentration and streamflow for Soda Butte Creek near Silvergate, Montana, a typical snowmelt-runoff site, water years 1999-2001. 


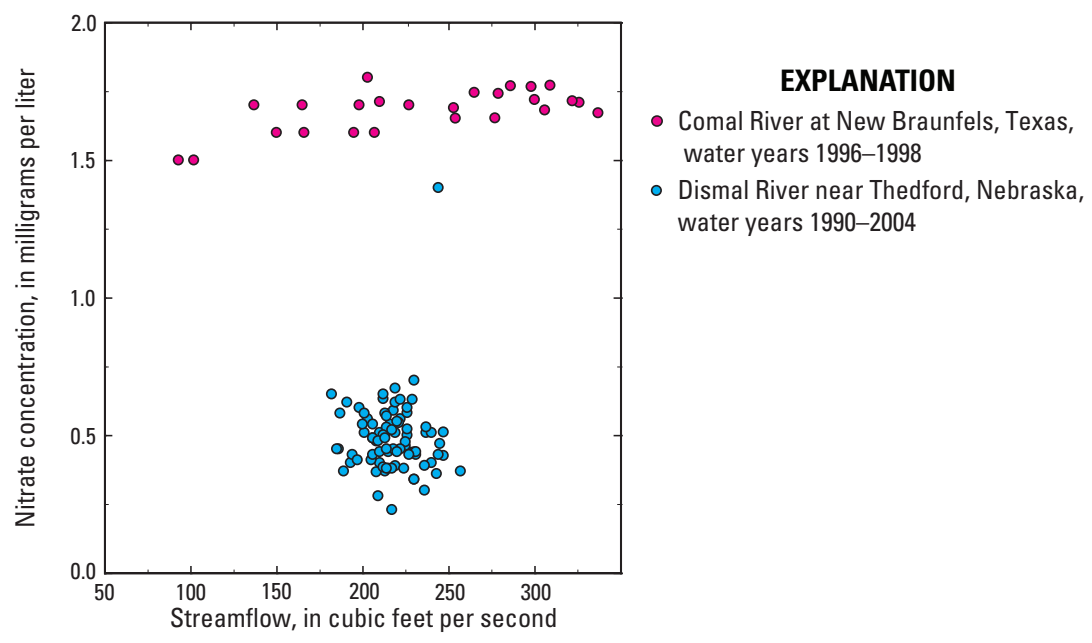

Figure 9. Relation of nitrate concentration and streamflow for two sites where streamflow and nitrate load are almost entirely contributed by groundwater discharge.

\section{Regional Processes Affecting Base-Flow Loads}

Climate, soils and bedrock permeability, and landsurface slope are among the many landscape characteristics that affect the mode of transport of nitrate from sources in a landscape to a stream. As with the base-flow index values (fig. 3), the effect of the characteristics of contrasting hydrologic landscapes on the sources of nitrate loads in streams was evaluated by grouping sites into one of four landscape categories: landscapes with permeable soils and permeable bedrock, landscapes with permeable soils and impermeable bedrock, landscapes with impermeable soils and permeable bedrock, and landscapes with impermeable soils and impermeable bedrock (Wolock and others, 2004). While there is a large amount of variability within each group, a significantly lower proportion of the nitrate load is derived from base flow at sites in areas with impermeable soils and impermeable bedrock than in the other landscapes (fig. 10). These sites tend to have lower base-flow index values as shown in figure 3. Additionally, the nitrate concentrations are lower during base-flow conditions as compared to higher flow periods for the majority of these sites.

Landscapes with impermeable soils and impermeable bedrock are areas where overland flow is the dominant mechanism of streamflow generation. Landscapes with these characteristics are common in the productive agricultural land in the Midwest and eastern portions of the Northern and Southern Plains (fig. 1). These areas, as well as similar areas where the majority of the nitrate load in streams is not delivered by base flow, could be most responsive to nutrient management practices designed to reduce nutrient transport to streams by runoff. Conversely, in areas where a large proportion of the stream nitrate load is derived from base flow, which is derived primarily from groundwater, changes in nutrient management focused on transport by runoff will have less effect on stream loads. Rather, changes in nutrient management could include consideration of contributions from groundwater in these areas, and improvements in stream nitrate concentrations will not take place until the nitrate concentration in the groundwater reaching the stream decreases. As with base-flow index, the relative ranking of bedrock and soil permeability does not differentiate nitrate base-load proportion in categories with some degree of permeable soils or bedrock (the three categories on the right in the figure 10 box plot). These categories - representing a deep groundwater component, a shallow groundwater component, and a combination of deep and shallow groundwater contributions of nitrate - are not statistically different. Refinement of permeability and landscape categories may be necessary to further categorize the base-flow nitrate load contribution.

Annual variations in streamflow (wet or dry cycles) could affect the relative proportions of the sources of streamflow and thus the nitrate load ratios. To investigate the effect of changes in streamflow volume on nitrate load ratios, Spearman correlation coefficients between annual nitrate load ratio and mean annual streamflow were determined for each of the 68 sites that had 5 or more years of simulated loads. Seventy-eight percent of these sites had no significant correlation. All but 2 of the 15 sites with statistically significant correlations between nitrate load and streamflow had negative rho values (higher streamflow periods resulted in lower proportion of nitrate contributed during base-flow periods). These 15 sites are located throughout the country and throughout the hydrologic landscape categories. While it appears that there is potential to bias load-ratio results when data only are available for wet or dry periods, the problem for this data set is not extensive. 

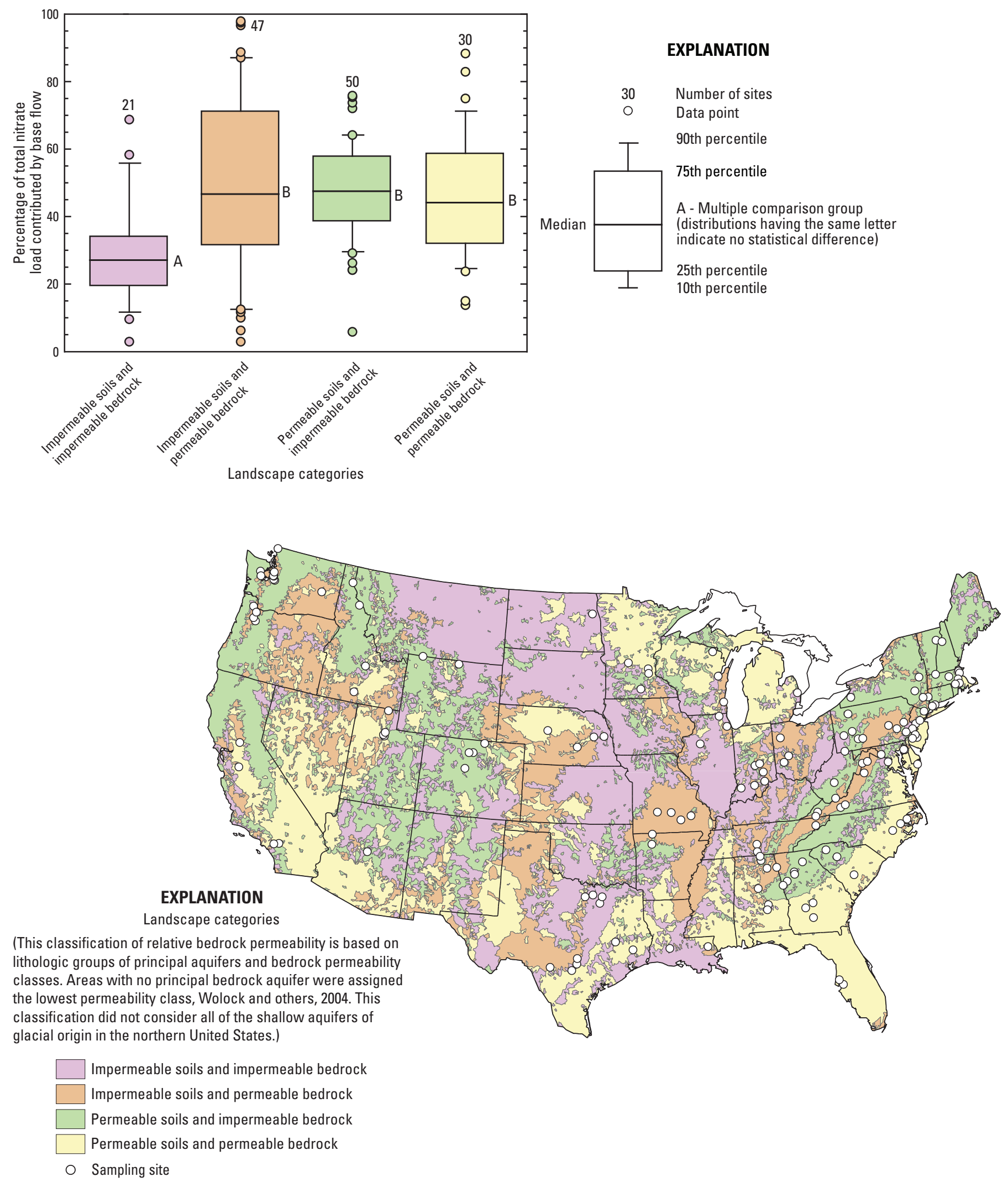

Figure 10. Distribution of nitrate load percentage by hydrologic landscape categories. 


\section{Nitrate Concentrations in Surface- Water Base Flow and Shallow Groundwater}

Mean annual base-flow nitrate concentrations were determined by dividing the base-flow nitrate load for the estimation time period by the base-flow streamflow. Land use, and the associated nonpoint sources of nutrients, were used to assess the distribution of base-flow nitrate concentrations. Comparison of nitrate concentrations in surface-water base flow to shallow groundwater-nitrate concentrations can indicate potential pathways of the movement of nitrogen to streams, and illustrate the potential effect of the movement of shallow groundwater to streams.

\section{Nitrate Concentrations in Surface-Water Base Flow}

The spatial distribution of base-flow nitrate concentrations follow the same general patterns as that described for nitrogen in the Nation's streams (Mueller and Spahr, 2006) (fig. 11, concentration data are given in table 5 in the Supplemental Information Section of this report). Higher concentrations are found in areas of higher nutrient sources: the greatest concentrations of total nitrogen and nitrate nitrogen were found at agricultural sites in the Midwest, Northeast, and Northwest areas of the country, and the relatively lower concentrations were found at undeveloped sites throughout the country (Mueller and Spahr, 2006). A comparison among land-use categories shows that concentrations are greatest at agricultural sites followed by the mixed, urban, and undeveloped categories (fig. 12). Sites in undeveloped areas have significantly lower concentrations than sites located in developed areas. The relative ranking in the distributions of concentrations by land-use category is similar to that presented by Mueller and Spahr (2006, page 29). However, sites with known point source discharges were removed from the analysis in the present report resulting in lower overall distributions for the urban and mixed land-use categories. As with total flow nitrate concentrations, the distributions of base-flow concentrations depend on nutrient sources and transport mechanisms. One mechanism that can be important is surface-water/ groundwater interactions.

\section{Comparison of Nitrate Concentrations in Surface-Water Base Flow and Shallow Groundwater}

Networks of monitoring wells established to investigate land-use effects on nutrient conditions in groundwater were selected to compare to surface-water conditions for 27 of the 148 sites. The mean annual base-flow nitrate concentrations were compared with the network median nitrate concentrations in shallow groundwater for these 27 sites (fig. 13, concentration data given in table 6 in the Supplemental Information Section of this report). Although the nitrate concentrations in base flow and shallow groundwater are often similar, nitrate concentrations in groundwater are more often greater than nitrate concentration in base flow for this group of sites (fig. 13). Areas where the contrast between elevated groundwater concentration and low base-flow concentration are greatest commonly have both permeable soils and permeable bedrock, conditions that enhance infiltration of water. Most of these areas also have groundwater that is predominantly oxic, the chemical environment in which nitrate is stable. These characteristics - high infiltration and oxic conditions - favor nitrate transport and persistence in groundwater. The lack of correspondingly high concentrations in the base flow of the paired surface-water sites may have multiple causes. In some settings, there has not been sufficient time for enough high-nitrate shallow groundwater to migrate to the nearby stream. In these cases, the stream nitrate concentrations lag behind those in the shallow groundwater, and concentrations may increase in the future as more high-nitrate groundwater reaches the stream. Alternatively, some of these sites may have processes that rapidly remove nitrate as water moves from the aquifer into the stream channel. For example, high denitrification rates in the riparian sediments along Fishtrap Creek remove nitrate from groundwater before it enters the stream (Tesoriero and others, 2000).

Three sites where base-flow concentrations are elevated, yet median groundwater concentrations are low, occur in areas with impermeable soils and impermeable bedrock (Black River, Kessinger Ditch, and Nippersink Creek in figure 13). These sites are in agricultural or mixed land-use areas in the Midwest with large nitrogen input from fertilizer, and with subsurface tile drainage systems (Natural Resources Conservation Service, 1995). In these areas, nitrate concentrations in groundwater are highly variable, and decrease greatly with depth from a maximum of $17 \mathrm{mg} / \mathrm{L}$ in shallow oxic groundwater near the water table, to consistently less than the laboratory reporting level in samples from greater than 25 feet below the water table. The high nitrate concentrations in the baseflow samples at these sites likely represent a combination of contributions of high nitrate water from the recession period of subsurface tile drainage during the wetter winter and spring seasons and moderate nitrate concentrations resulting from the discharge of a mixture of shallow high-nitrate groundwater and deeper low-nitrate groundwater during the drier summer and fall seasons when drains rarely flow. Despite the contribution of some nitrate load during base flow, at these sites overland flow and tile drainage is the predominant source of streamflow and nitrate load (base-flow nitrate load ratios of 44 percent or less).

Nitrate concentrations are elevated in both base flow and shallow groundwater in the vicinity of Tulpehocken Creek (fig. 13). This site is located in an agricultural area of eastern Pennsylvania with highly permeable underlying rocks (Fischer and others, 2004). Manure from livestock operations 


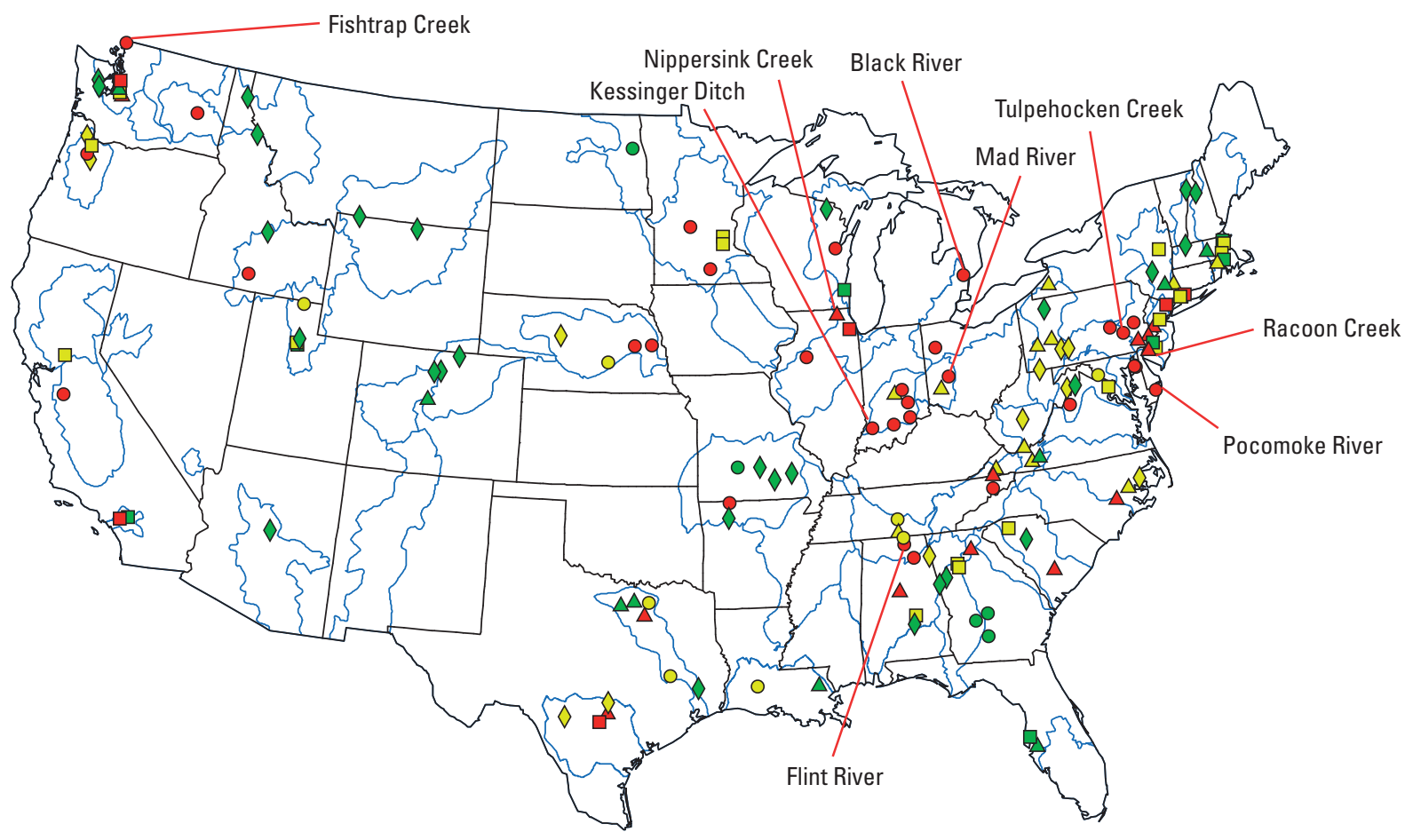

EXPLANATION

\begin{tabular}{|c|c|c|c|c|}
\hline \multicolumn{4}{|c|}{ Site Type (number of sites) } & \\
\hline $\begin{array}{l}\text { Urban } \\
\text { (31) }\end{array}$ & $\begin{array}{c}\text { Agricultural } \\
\text { (43) }\end{array}$ & $\begin{array}{l}\text { Undeveloped } \\
\qquad(40)\end{array}$ & $\begin{array}{l}\text { Mixed } \\
(34)\end{array}$ & $\begin{array}{l}\text { milligrams per liter } \\
\text { (number of sites) }\end{array}$ \\
\hline & 0 & $\diamond$ & $\triangle$ & Less than or equal to 0.39 (49) \\
\hline$\square$ & $\bigcirc$ & $\diamond$ & $\triangle$ & From 0.39 through $1.25(50)$ \\
\hline$\square$ & 0 & & $\triangle$ & Greater than 1.25 (49) \\
\hline
\end{tabular}

Figure 11. Spatial distribution of mean annual base-flow nitrate concentrations.

commonly is applied to farm fields in this area. Lindsey and others (1998) describe the rapid infiltration of nitrate from fertilizer and manure in other agricultural areas of Pennsylvania with similar shallow and highly permeable bedrock. The correspondence between groundwater and base-flow nitrate concentrations indicates a fairly rapid and unattenuated transport of nitrate in groundwater to this stream.

Tesoriero and others (2009) used the relation of concentration and base-flow index to identify nutrient sources. They demonstrated that for sites where base flow generates a large component of the nitrate load, a groundwater source of nitrate is indicated by the combination of a positive correlation between nitrate concentration and base-flow index corresponding to the date of sampling and the correspondence between groundwater concentrations and the concentration in streams during periods with high base-flow index values. This type of relation was observed in the current study for some sites
(Tulpehocken Creek and the Flint River, fig. 14). However other types of relations also were observed. For example, the Mad River has more than 60 percent of the nitrate load contributed during base-flow conditions but concentrations of nitrogen associated with quicker-flow sources (lower baseflow index values) can have elevated concentrations. The relation can become more complex for sites with less than 50 percent of the load contributed during base-flow conditions and reverse for sites where base flow contributes a minor portion of the nitrate load (Pocomoke River and Black River, fig. 14). Stream nitrate concentrations at high base-flow index values are substantially lower than the median concentration in shallow groundwater for the Racoon Creek site (fig. 14). This lack of correspondence was noted for other sites in the Atlantic Coastal Plain and indicates denitrification in the aquifer near the streams or by in-stream processes (Ayers and others, 2000). 


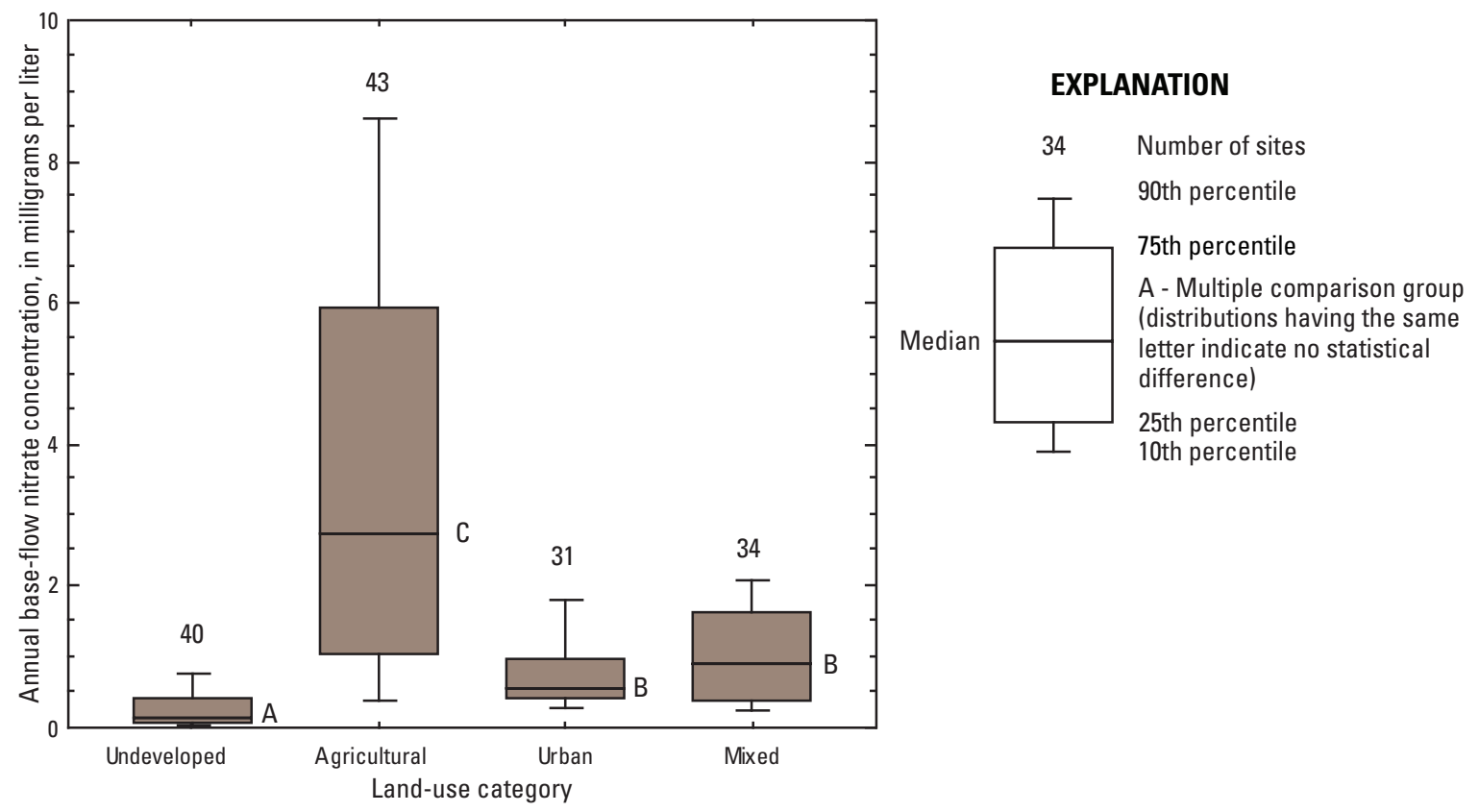

Figure 12. Distribution of surface-water base-flow nitrate concentrations by land-use category.

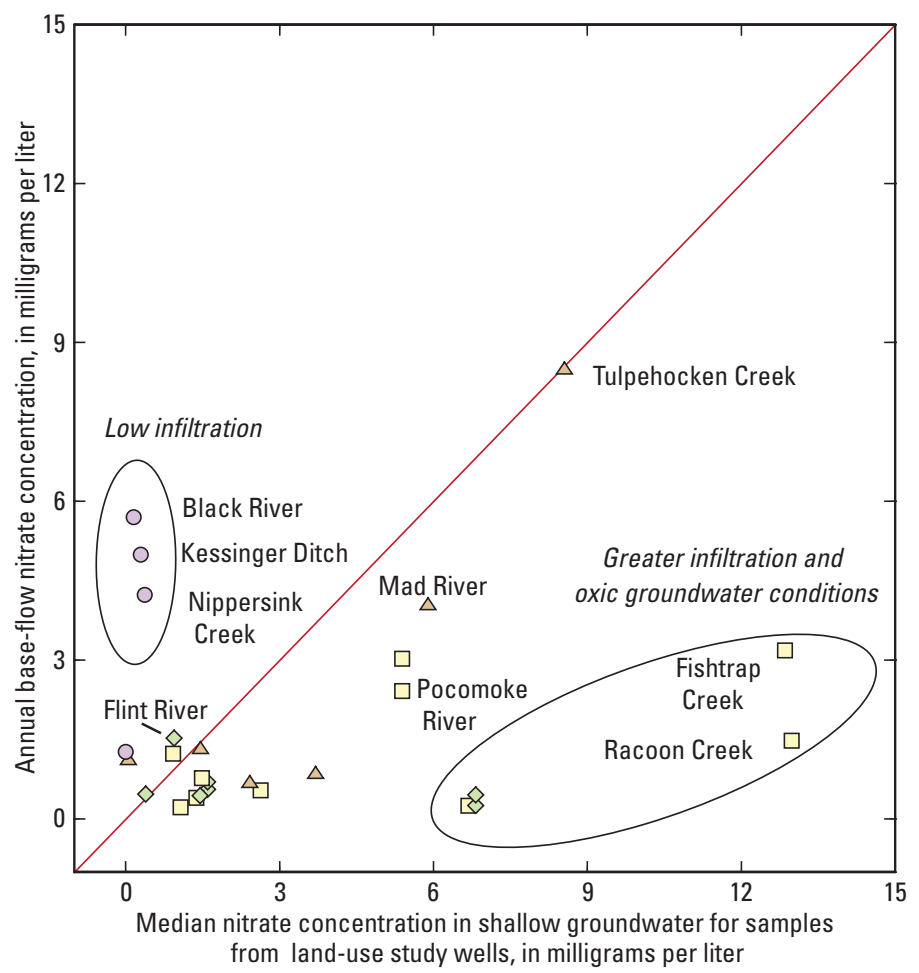

\section{EXPLANATION}

O Impermeable soils and impermeable bedrock

$\Delta$ Impermeable soils and permeable bedrock

$\diamond$ Permeable soils and impermeable bedrock

$\square$ Permeable soils and permeable bedrock

Figure 13. Comparison of nitrate concentrations in base flow and shallow groundwater for selected National Water-Quality Assessment sampling sites. 

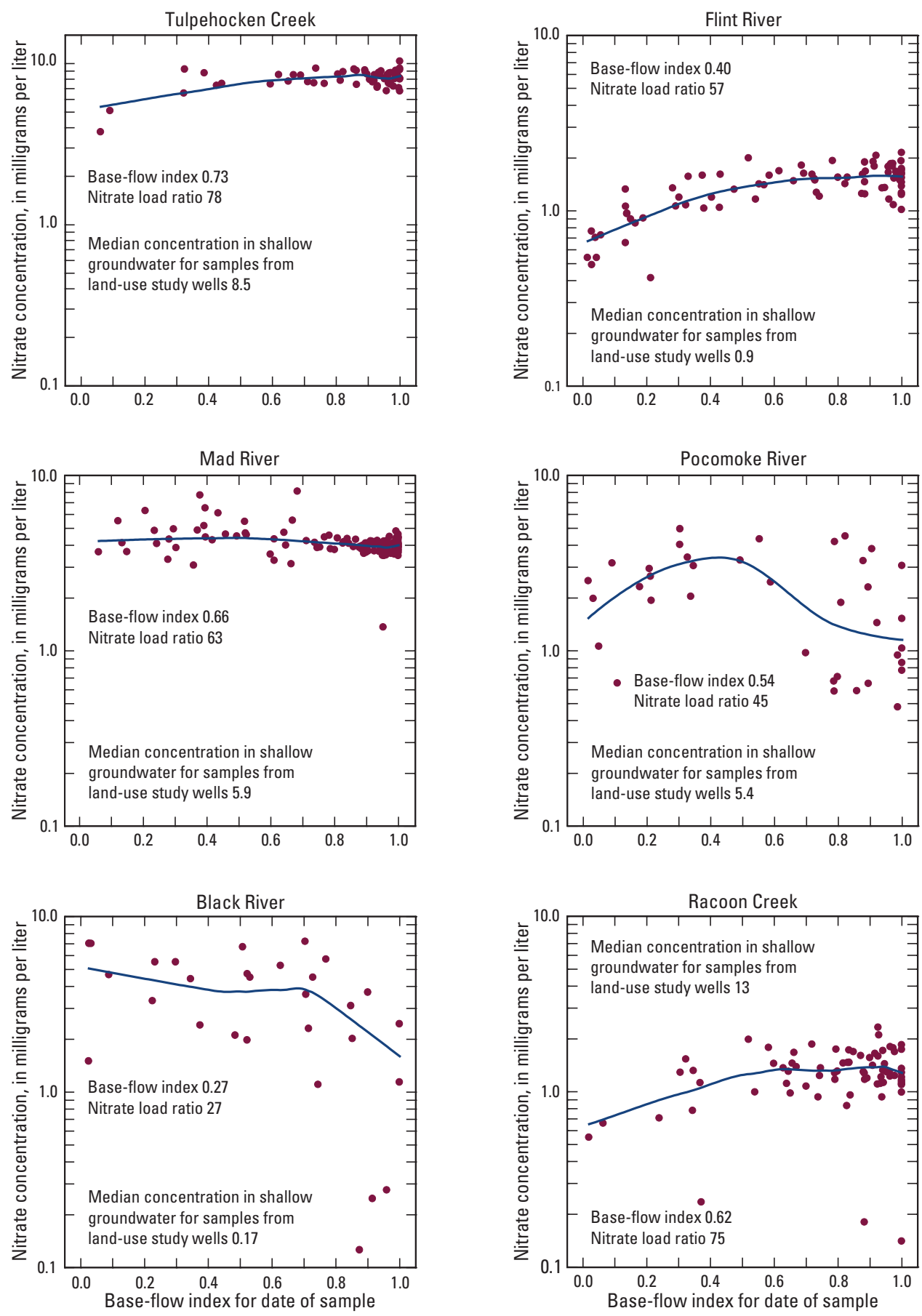

EXPLANATION

- Nitrate sample

LOWESS smooth

Figure 14. Relation of concentration to base-flow index corresponding to the date of sampling for selected National Water-Quality Assessment sampling sites. 
Tesoriero and others (2009) further compared the concentrations near the end of these relations (high base-flow index values) to concentrations found in streambed pore water, riparian zone, and upland groundwater to infer flow-path mechanisms. The similarity in groundwater-nitrate concentrations and base-flow nitrate concentrations coupled with the lack of correspondence between base-flow nitrate concentrations and pore-water nitrate concentrations indicate preferential groundwater-flow paths as the source of nitrate during base-flow conditions (Tesoriero and others, 2000). Extensive flow-path data, such as pore-water concentrations and riparian zone concentrations, routinely were not collected as part of the NAWQA basic fixed site network and is unavailable for the current study. Groundwater-flow paths, preferential flow paths, hyporheic zone conditions, riparian zone processes, artificial drainage, runoff, biologic uptake, and nitrogen sources are among the many processes that make comparison of surface-water and groundwater nitrate concentrations a complex problem.

Partitioning streamflow and nitrate load between the quick-flow and base-flow portions of the hydrograph coupled with relative scales of soil permeability can infer the importance of surface-water compared to groundwater nitrate sources. Study of the relation of nitrate concentrations to base-flow index and the comparison of groundwater nitrate concentrations to stream nitrate concentrations during times when the base-flow index is high can provide evidence of potential nitrate transport mechanisms. These tools, regional study of the relative importance of surface-water compared to groundwater contributions of nitrate, and further integration of surface-water and groundwater data collection networks can assist in the selection of appropriate nutrient management strategies. Accounting for the surface-water and groundwater contributions of nitrate is crucial to effective management and remediation of nutrient enrichment in streams.

\section{Summary}

Concentrations of nutrients in streams vary with the source of streamflow. Knowledge of the contribution of base flow to the nutrient load can assist in determining the applicability of nutrient management strategies. Sites with drainage areas less than 500 square miles that were sampled as part of the basicfixed site network for the NAWQA program were selected for investigation. Based on comments from NAWQA study unit personnel, sites with potential effect from wastewater treatment facilities or impoundments were excluded from analysis.

Hydrograph separation techniques were used to determine the ratio of base flow to total flow (base-flow index) for the 148 sites. Sites in the Southwest and the Northwest tend to have base-flow index values greater than 0.5 . Sites in the Midwest and the eastern portion of the Southern Plains generally have values less than 0.5 . Base-flow index values for sites in the Southeast and Northeast are mixed with values less than and greater than 0.5 . Categories of hydrologic landscapes based on soil and bedrock permeability explain some of the differences found in base-flow index. Areas with impermeable soils and impermeable bedrock tend to have lower base-flow index values. These are areas where overland flow may be an important hydrologic flow path.

The percentage of total nitrate load contributed by base flow was determined by developing total flow and base-flow nitrate load models. These regression-based models were calibrated using available nitrate samples and total streamflow or base-flow nitrate samples and the base-flow component of total streamflow.

Many streams in the country have a large proportion of nitrate load contributed by base flow: 40 percent of sites have more than 50 percent of the total nitrate load contributed by base flow. Sites in the Northern Plains and Northwest have nitrate load ratios that generally are greater than 50 percent. Nitrate load ratios for sites in the Southeast and Northeast are mixed with values less than and greater than 50 percent. The proportion of nitrate load contributed by base flow (load ratio) generally is less than 50 percent for sites in the Midwest and eastern portion of the Southern Plains. Sites in eastern Texas have low nitrate load ratios (less than 25 percent) as a result of low nitrate concentrations during periods of low flow followed by short duration runoff events with higher nitrate concentrations. Low nitrate-load ratios also are found in streams in the eastern portion of the Midwest (Indiana and Ohio). Tile-drainage systems, common in this area, can intercept nitrate-rich shallow groundwater resulting in high nitrate concentrations when the tile drains are flowing.

Sites underlain by the Valley and Ridge carbonate aquifer in the Valley and Ridge physiographic province (northern Alabama through Tennessee, Virginia, Maryland, and Pennsylvania) have more than 70 percent of the nitrate load contributed by base flow. The shallow permeable bedrock can result in extensive interaction between surface water and groundwater.

Two sites where groundwater contributions are well documented (the Dismal River in Nebraska and the Comal River in Texas) have about 98 percent of the nitrate load contributed by base flow. The relation between nitrate concentration and streamflow at these sites is relatively invariant.

The effect of the characteristics of contrasting hydrologic landscapes on the sources of nitrate loads in streams is shown by grouping sites into one of four landscape categories: landscapes with permeable soils and permeable bedrock, landscapes with permeable soils and impermeable bedrock, landscapes with impermeable soils and permeable bedrock, and landscapes with impermeable soils and impermeable bedrock. Significantly lower contributions of nitrate from base flow were found in areas with impermeable soils and impermeable bedrock. These areas could be most responsive to nutrient management practices designed to reduce nutrient transport to streams by runoff. Conversely, sites with potential for shallow or deep groundwater contribution (some combination of permeable soils or permeable bedrock) had significantly greater contributions of nitrate from base flow. Effective nutrient management strategies would consider groundwater nitrate contributions in these areas. 
Mean annual base-flow nitrate concentrations are greater at agricultural sites in the Midwest, Northeast, and Northwest areas of the country and are relatively lower at undeveloped sites throughout the country. Comparison of the distributions of base-flow nitrate concentrations by land use show that concentrations are greatest at agricultural sites followed by the mixed, urban, and undeveloped categories.

Mean annual base-flow concentrations were compared to shallow-groundwater concentrations for 27 of the 148 sites. Nitrate concentrations in groundwater tended to be greater than base-flow concentrations for this group of sites. Sites where groundwater concentrations were much greater than base-flow concentrations were found in areas of high infiltration and oxic groundwater conditions. The lack of correspondingly high concentrations in the base flow of the paired surface-water sites may have multiple causes. In some settings, there has not been sufficient time for enough high-nitrate shallow groundwater to migrate to the nearby stream. In these cases, the stream nitrate concentrations lag behind those in the shallow groundwater, and concentrations may increase in the future as more highnitrate groundwater reaches the stream. Alternatively, some of these sites may have processes that rapidly remove nitrate as water moves from the aquifer into the stream channel.

Partitioning streamflow and nitrate load between the quick-flow and base-flow portions of the hydrograph coupled with relative scales of soil permeability can infer the importance of surface water compared to groundwater nitrate sources. Study of the relation of nitrate concentrations to base-flow index and the comparison of groundwater nitrate concentrations to stream nitrate concentrations during times when base flow index is high can provide evidence of potential nitrate transport mechanisms. Accounting for the surface-water and groundwater contributions of nitrate is crucial to effective management and remediation of nutrient enrichment in streams.

\section{Acknowledgments}

This report relies on water samples that were collected by hydrologists and hydrologic technicians in 51 NAWQA study units and analyzed by technicians at the USGS National Water Quality Laboratory in Denver, Colorado. Without all their diligent efforts, the data interpretation in this report would not have been possible.

Bruce Lindsey, Karen Burow, and Betty Palcsak of the U.S. Geological Survey provided valuable comments on the report. The authors also thank Kristi Hartley for editorial review and Mari L. Kauffmann (Contractor, ATA Services) for manuscript preparation, layout, and illustration assistance.

\section{References}

Akaike, Hirotugu, 1981, Likelihood of a model and information criterion: Journal of Econometrics, v. 16, p. 3-14.

Arnold, J.G., Allen, P.M., Muttiah, R., and Bernhardt, G., 1995, Automated baseflow separation and recession analysis techniques: Groundwater, v. 33, no. 6, p. 1010-1018.

Ayers, M.A., Kennen, J.G., and Stackelberg, P.E., 2000, Water quality in the Long Island-New Jersey coastal drainages, New York and New Jersey, 1996-98: U.S. Geological Survey Circular 1201, 40 p.

Bachman, L.J., Lindsey, B.D., Brakebill, J.W., and Powars, D.S., 1998, Ground-water discharge and base-flow nitrate loads of nontidal streams, and their relation to a hydrogeomorphic classification of the Chesapeake Bay Watershed, Middle Atlantic Coast: U.S. Geological Survey WaterResources Investigations Report 98-4059, 71 p.

Conover, W.J., and Iman, R.L., 1981, Rank transformation as a bridge between parametric and nonparametric statistics: The American Statistician, v. 35, no. 3, p. 124-129.

Cohn, T.A., Gilroy, E.J., and Baier, W.G., 1992, Estimating fluvial transport of trace constituents using a regression model with data subject to censoring, in Proceedings of the Section on Statistics and the Environment: Boston, Mass., American Statistical Association, August 9-13, 1992, p. 142-151.

Fenelon, J.M., 1998, Water quality in the White River Basin, Indiana, 1992-96: U.S. Geological Survey Circular 1150, 34 p.

Fischer, J.M., Riva-Murray, Karen, Hickman, R.E., Chichester, D.C., Brightbill, R.A., Romanok, R.M., and Bilger, M.D., 2004, Water quality in the Delaware River Basin, Pennsylvania, New Jersey, New York, and Delaware, 1998-2001: U.S. Geological Survey Circular 1227, 38 p.

Frenzel, S.A., Swanson, R.B., Huntzinger, T.L., Stamer, J.K., Emmons, P.J., and Zelt, R.B., 1998, Water quality in the Central Nebraska Basins, Nebraska, 1992-95: U.S. Geological Survey Circular 1163, 33 p.

Garg, V., Chaubey, I., Haggard, B.E., 2003, Impact of calibration watershed on runoff model accuracy: Transactions of the American Society of Agricultural Engineers, v. 46, no. 5, p. $1347-1353$.

Ging, P.B., and Otero, C.L., 2003, Comparison of temperature, specific conductance, $\mathrm{pH}$, and dissolved oxygen at selected basic fixed sites in south-central Texas, 1996-98: U.S. Geological Survey Open-File Report 03-087, 18 p.

Groschen, G.E., Arnold, T.L., Harris, M.A., Dupre, D.H., Fitzpatrick, F.A., Scudder, B.C., Morrow, W.S., Jr., Terrio, P.J., Watner, K.L., and Murphy, E.A., 2004, Water quality in the Upper Illinois River Basin, Illinois, Indiana, and Wisconsin, 1999-2001: U.S. Geological Survey Circular 1230, 32 p. 
Halford, K.J., and Mayer, G.C., 2000, Problems associated with estimating ground water discharge and recharge from streamdischarge records: Ground Water, v. 38, no. 3, p. 331-342.

Hampson, P.S., Treece, M.W, Jr., Johnson, G.C., Ahlstedt, S.A., and Connell, J.F., 2000, Water quality in the Upper Tennessee River Basin, Tennessee, North Carolina, Virginia, and Georgia, 1994-98: U.S. Geological Survey Circular 1205, 32 p.

Helsel, D.R., and Hirsch, R.M., 1992, Statistical methods in water resources: Amsterdam, Elsevier Science B.V., 529 p.

Institute of Hydrology, 1980, Low flow studies: Wallingford, Oxon, United Kingdom, Report No. 1, 41 p.

Jordan, T.E., Correll, D.L., and Weller, D.E., 1997, Relating nutrient discharges from watersheds to land use and streamflow variability: Water Resources Research, v. 33, no. 11 , p. 2579-2590.

Land, L.F., Moring, J.B., Van Metre, P.C., Reutter, D.C., Mahler, B.J., Shipp, A.A., and Ulery, R.L., 1998, Water quality in the Trinity River Basin, Texas, 1992-95: U.S. Geological Survey Circular 1171, 39 p.

Langland, M.J., Lietman, P.L, and Hoffman S.A., 1995, Synthesis of nutrient and sediment data for watersheds within the Chesapeake Bay Drainage Basin: U.S. Geological Survey Water-Resources Investigations Report 95-4233, 121 p.

Lindsey, B.D., Breen, K.J., Bilger, M.D., and Brightbill, R.A., 1998, Water quality in the Lower Susquehanna River Basin, Pennsylvania and Maryland, 1992-95: U.S. Geological Survey Circular 1168, 38 p.

Lindsey, B.D., Berndt, M.P., Katz, B.G., Ardis, A.F., and Skach, K.A., 2009, Factors affecting water quality in selected carbonate aquifers in the United States, 1993-2005: U.S. Geological Survey Scientific Investigations Report 2008-5240, $117 \mathrm{p}$

Maidment, D.R., ed., 1993, Handbook of hydrology: New York, N.Y., McGraw-Hill, Inc., variously paged.

Mueller, D.K., and Spahr, N.E., 2005, Water-quality, streamflow, and ancillary data for nutrients in streams and rivers across the Nation, 1992-2001: U.S. Geological Survey Data Series 152, accessed July 2007 at http://pubs.usgs.gov/ds/2005/152/.

Mueller, D.K., and Spahr, N.E., 2006, Nutrients in streams and rivers across the Nation: U.S. Geological Survey Scientific Investigations Report 2006-5107, 44 p.

Mullaney, J.R., 2007, Nutrient loads and ground-water residence times in an agricultural basin in north-central Connecticut: U.S. Geological Survey Scientific Investigations Report 2006-5278, 45 p.

Natural Resources Conservation Service, 1995, 1992 National resources inventory: U.S. Department of Agricultural, Natural Resources Conservation Service.
Neff, B.P., Day, S.M., Piggott, A.R., Fuller, L.M., 2005, Base flow in the Great Lakes Basin: U.S. Geological Survey Scientific Investigations Report 2005-5217, 23 p.

Runkel, R.L., Crawford, C.G., and Cohn, T.A., 2004, Load estimator (LOADEST) —A FORTRAN program for estimating constituent loads in streams and rivers: U.S. Geological Survey Techniques and Methods, book 4, chap. A5, 69 p.

Rutledge, A.T., 1998, Computer programs for describing the recession of ground-water discharge and for estimating mean ground-water recharge and discharge from streamflow records - update: U.S. Geological Survey Water-Resources Investigations Report 98-4148, 43 p.

Santhi, C., Allen, P.M., Muttiah, R.S., Arnold, J.G., and Tuppad P., 2008, Regional estimation of base flow for the conterminous United States by hydrologic landscape regions: Journal of Hydrology, v. 351, no. 1-2, p. 139-153.

Sloto, R.A., and Crouse, M.Y., 1996, HYSEP; a computer program for streamflow hydrograph separation and analysis: U.S. Geological Survey Water-Resources Investigations Report 96-4040, 46 p.

Tesoriero, A.J., Duff, J.H., Wolock, D.M., and Spahr, N.E., 2009, Identifying pathways and processes affecting nitrate and orthophosphate inputs to streams in agricultural watersheds: Journal of Environmental Quality, v. 38, p. 1892-1900.

Tesoriero, A.J., Liebscher, H., and Cox, S.E., 2000, Mechanism and rate of denitrification in an agricultural watershedElectron and mass balance along groundwater flow paths: Water Resources Research, v. 36, no. 6, p. 1545-1559.

Wahl, T.L., and Wahl, K.L., 1988, BFI A computer program for determining an index to base flow: accessed July 2007 at http://www.usbr.gov/pmts/hydraulics_lab/twahl/bfi/ index.html.

Winter, T.C., 2001, The concept of hydrologic landscapes: Journal of the American Water Resources Association, v. 37 no. 2 , p. 335-349.

Winter, T.C., Harvey, J.W., Franke, O.L., and Alley, W.M., 1998, Ground water and surface water-a single resource: U.S. Geological Survey Circular 1139, 79 p.

Wolock, D.M, 2003, Hydrologic landscape regions of the United States: U.S. Geological Survey Open-File Report 03-145, accessed September 2009, at http://water.usgs.gov/ GIS/metadata/usgswrd/XML/hlrus.xml

Wolock, D.M., Winter, T.G., and McMahon, G., 2004, Delineation and evaluation of hydrologic-landscape regions in the United States using geographic information system tools and multivariate statistical analyses: Environmental Management, v. 34, suppl. 1, p. S71-S88. 
Supplemental Information 
Table 1. Site location, drainage area, and land-use classification.

[Ag, Agriculture; Undev, undeveloped]

\begin{tabular}{|c|c|c|c|c|c|c|c|}
\hline $\begin{array}{l}\text { U.S. Geological } \\
\text { Survey site number }\end{array}$ & Site name & $\begin{array}{l}\text { Study unit } \\
\text { identifier }\end{array}$ & Study unit name & $\begin{array}{l}\text { Latitude } \\
\text { (decimal } \\
\text { degrees) }\end{array}$ & $\begin{array}{l}\text { Longitude } \\
\text { (decimal } \\
\text { degrees) }\end{array}$ & $\begin{array}{c}\text { Drainage } \\
\text { area (square } \\
\text { miles) }\end{array}$ & $\begin{array}{l}\text { Land-use } \\
\text { classification }\end{array}$ \\
\hline site & site_name & suid & su_name & lat & long & drain_area_sqmi & circular_lu \\
\hline 07375050 & Tchefuncte River near Covington, LA & ACAD & Acadian-Pontchartrain Drainages & 30.49464 & -90.16950 & 141 & Mixed \\
\hline 08010000 & Bayou Des Cannes near Eunice, LA & ACAD & Acadian-Pontchartrain Drainages & 30.48353 & -92.49040 & 142 & $\mathrm{Ag}$ \\
\hline 02332830 & West Fork Little River near Clermont, GA & ACFB & Apalachicola-Chattahoochee-Flint River Basins & 34.41538 & -83.82160 & 18 & Mixed \\
\hline 02335870 & Sope Creek near Marietta, GA & ACFB & Apalachicola-Chattahoochee-Flint River Basins & 33.95399 & -84.44330 & 31 & Urban \\
\hline 02336300 & Peachtree Creek at Atlanta, GA & ACFB & Apalachicola-Chattahoochee-Flint River Basins & 33.81955 & -84.40770 & 86 & Urban \\
\hline 02337500 & Snake Creek near Whitesburg, GA & ACFB & Apalachicola-Chattahoochee-Flint River Basins & 33.52956 & -84.92830 & 36 & Undev \\
\hline 02338523 & Hillibahatchee Creek near Franklin, GA & ACFB & Apalachicola-Chattahoochee-Flint River Basins & 33.34056 & -85.22694 & 17 & Undev \\
\hline 02350080 & Lime Creek near Cobb, GA & ACFB & Apalachicola-Chattahoochee-Flint River Basins & 32.03517 & -83.99240 & 62 & $\mathrm{Ag}$ \\
\hline 02084160 & Chicod Creek near Simpson, NC & ALBE & Albemarle-Pamlico Drainages & 35.56322 & -77.22830 & 42 & Mixed \\
\hline 02084557 & Van Swamp near Hoke, NC & ALBE & Albemarle-Pamlico Drainages & 35.73044 & -76.74660 & 22 & Undev \\
\hline 0208925200 & Bear Creek at Mays Store, NC & ALBE & Albemarle-Pamlico Drainages & 35.27461 & -77.79410 & 59 & Mixed \\
\hline 03015795 & East Hickory Creek near Queen, PA & ALMN & Allegheny-Monongahela River Basins & 41.64201 & -79.33810 & 20 & Undev \\
\hline 03037350 & South Branch Plum Creek at Five Points, PA & ALMN & Allegheny-Monongahela River Basins & 40.71895 & -79.23640 & 33 & Mixed \\
\hline 03040000 & Stonycreek River at Ferndale, PA & ALMN & Allegheny-Monongahela River Basins & 40.28563 & -78.92060 & 452 & Undev \\
\hline 03049646 & Deer Creek near Dorseyville, PA & ALMN & Allegheny-Monongahela River Basins & 40.58257 & -79.86120 & 27 & Mixed \\
\hline 03072000 & Dunkard Creek at Shannopin, PA & ALMN & Allegheny-Monongahela River Basins & 39.75925 & -79.97060 & 227 & Undev \\
\hline 09505800 & West Clear Creek near Camp Verde, AZ & CAZB & Central Arizona Basins & 34.53864 & -111.69400 & 237 & Undev \\
\hline 12464770 & Crab Creek near Ritzville, WA & CCYK & Central Columbia Plateau (CCPT)-Yakima River Basin (YAKI) & 47.30265 & -118.36900 & 459 & Ag \\
\hline 06773050 & Prairie Creek near Ovina, NE & CNBR & Central Nebraska Basins & 40.98418 & -98.41670 & 140 & Ag \\
\hline 06775900 & Dismal River near Thedford, NE & CNBR & Central Nebraska Basins & 41.77916 & -100.52500 & 28 & Undev \\
\hline 06795500 & Shell Creek near Columbus, NE & CNBR & Central Nebraska Basins & 41.52584 & -97.28230 & 294 & $\mathrm{Ag}$ \\
\hline 06800000 & Maple Creek near Nickerson, NE & CNBR & Central Nebraska Basins & 41.56083 & -96.54110 & 368 & $\mathrm{Ag}$ \\
\hline 01135300 & Sleepers River near St. Johnsbury, VT & CONN & Connecticut, Housatonic, and Thames River Basins & 44.43450 & -72.03900 & 43 & Undev \\
\hline 01137500 & Ammonoosuc River at Bethlehem Junction, NH & CONN & Connecticut, Housatonic, and Thames River Basins & 44.26896 & -71.63060 & 88 & Undev \\
\hline 01170100 & Green River near Colrain, MA & CONN & Connecticut, Housatonic, and Thames River Basins & 42.70342 & -72.67060 & 41 & Undev \\
\hline 01199900 & Tenmile River near Wingdale, NY & CONN & Connecticut, Housatonic, and Thames River Basins & 41.66309 & -73.55960 & 193 & Mixed \\
\hline 01208873 & Rooster River at Fairfield, CT & CONN & Connecticut, Housatonic, and Thames River Basins & 41.18010 & -73.21860 & 10 & Urban \\
\hline 01209710 & Norwalk River at Winnipauk,CT & CONN & Connecticut, Housatonic, and Thames River Basins & 41.13509 & -73.42660 & 33 & Urban \\
\hline 01451800 & Jordon Creek near Schnecksville, PA & DELR & Delaware River Basin & 40.66176 & -75.62690 & 52 & $\mathrm{Ag}$ \\
\hline 01464907 & Little Neshaminy Creek near Warminster, PA & DELR & Delaware River Basin & 40.22927 & -75.11960 & 28 & Mixed \\
\hline 01467150 & Cooper River at Haddonfield, NJ & DELR & Delaware River Basin & 39.90317 & -75.02160 & 18 & Urban \\
\hline 01470779 & Tulpehocken Creek near Bernville, PA & DELR & Delaware River Basin & 40.41343 & -76.17160 & 69 & $\mathrm{Ag}$ \\
\hline 01472157 & French Creek near Phoenixville, PA & DELR & Delaware River Basin & 40.15149 & -75.60130 & 59 & Mixed \\
\hline 01477120 & Racoon Creek near Swedesboro, NJ & DELR & Delaware River Basin & 39.74123 & -75.25880 & 26 & Mixed \\
\hline 02215100 & Tucsawhatchee Creek near Hawkinsville, GA & GAFL & Georgia-Florida Coastal Plain Drainages & 32.23961 & -83.50160 & 162 & $\mathrm{Ag}$ \\
\hline 02300700 & Bullfrog Creek near Wimauma, FL & GAFL & Georgia-Florida Coastal Plain Drainages & 27.79197 & -82.35200 & 29 & Mixed \\
\hline
\end{tabular}


Table 1. Site location, drainage area, and land-use classification.-Continued

[Ag, Agriculture; Undev, undeveloped]

\begin{tabular}{|c|c|c|c|c|c|c|c|}
\hline $\begin{array}{l}\text { U.S. Geological } \\
\text { Survey site number }\end{array}$ & Site name & $\begin{array}{l}\text { Study unit } \\
\text { identifier }\end{array}$ & Study unit name & $\begin{array}{l}\text { Latitude } \\
\text { (decimal } \\
\text { degrees) }\end{array}$ & $\begin{array}{l}\text { Longitude } \\
\text { (decimal } \\
\text { degrees) }\end{array}$ & $\begin{array}{c}\text { Drainage } \\
\text { area (square } \\
\text { miles) }\end{array}$ & $\begin{array}{l}\text { Land-use } \\
\text { classification }\end{array}$ \\
\hline 02306774 & Rocky Creek near Citrus Park, FL & GAFL & Georgia-Florida Coastal Plain Drainages & 28.06556 & -82.56583 & 20 & Urban \\
\hline 02317797 & Little River near Tifton, GA & GAFL & Georgia-Florida Coastal Plain Drainages & 31.48185 & -83.58410 & 129 & $\mathrm{Ag}$ \\
\hline 10102200 & Cub River near Richmond, UT & GRSL & Great Salt Lake Basins & 41.92632 & -111.85400 & 223 & $\mathrm{Ag}$ \\
\hline 10167800 & Little Cottonwood Creek at Crestwood Park, UT & GRSL & Great Salt Lake Basins & 40.59995 & -111.83400 & 36 & Urban \\
\hline 10168000 & Little Cottonwood Creek at Salt Lake City, UT & GRSL & Great Salt Lake Basins & 40.66384 & -111.90200 & 45 & Urban \\
\hline 10172200 & Red Butte Creek at Fort Douglas, UT & GRSL & Great Salt Lake Basins & 40.77995 & -111.80600 & 7 & Undev \\
\hline 01356190 & Lisha Kill northwest of Niskayuna, NY & HDSN & Hudson River Basin & 42.78341 & -73.85710 & 15 & Urban \\
\hline 01362200 & Esopus Creek at Allaben, NY & HDSN & Hudson River Basin & 42.11703 & -74.38010 & 65 & Undev \\
\hline 01372051 & Fall Kill at Poughkeepsie, NY & HDSN & Hudson River Basin & 41.71009 & -73.92620 & 19 & Mixed \\
\hline 03167000 & Reed Creek at Grahams Forge, VA & KANA & Kanawha-New River Basin & 36.93957 & -80.88670 & 258 & Mixed \\
\hline 03170000 & Little River at Graysontown, VA & KANA & Kanawha-New River Basin & 37.03762 & -80.55670 & 307 & Mixed \\
\hline 03178000 & Bluestone River near Spanishburg, WV & KANA & Kanawha-New River Basin & 37.43345 & -81.11090 & 200 & Mixed \\
\hline 03191500 & Peters Creek near Lockwood, WV & KANA & Kanawha-New River Basin & 38.26261 & -81.02320 & 40 & Undev \\
\hline 04159492 & Black River near Jeddo, MI & LERI & Lake Erie-Lake St. Clair Drainages & 43.15253 & -82.62410 & 462 & $\mathrm{Ag}$ \\
\hline 04186500 & Auglaize River near Fort Jennings, OH & LERI & Lake Erie-Lake St. Clair Drainages & 40.94866 & -84.26610 & 331 & $\mathrm{Ag}$ \\
\hline 04213500 & Cattaraugus Creek at Gowanda, NY & LERI & Lake Erie-Lake St. Clair Drainages & 42.46395 & -78.93500 & 436 & Mixed \\
\hline 01390500 & Saddle River at Ridgewood, NJ & LINJ & Long Island-New Jersey Coastal Drainages & 40.98482 & -74.09130 & 22 & Urban \\
\hline 01398000 & Neshanic River at Reaville, NJ & LINJ & Long Island-New Jersey Coastal Drainages & 40.47177 & -74.82790 & 25 & Mixed \\
\hline 01403900 & Bound Brook at Middlesex, NJ & LINJ & Long Island-New Jersey Coastal Drainages & 40.58510 & -74.50770 & 49 & Urban \\
\hline 01410784 & Great Egg Harbor River near Sicklerville, NJ & LINJ & Long Island-New Jersey Coastal Drainages & 39.73400 & -74.95100 & 15 & Urban \\
\hline 05568800 & Indian Creek near Wyoming, IL & LIRB & Lower Illinois River Basin & 41.01837 & -89.83540 & 63 & $\mathrm{Ag}$ \\
\hline 01555400 & East Mahantango Creek at Klingerstown, PA & LSUS & Lower Susquehanna River Basin & 40.66342 & -76.69140 & 45 & $\mathrm{Ag}$ \\
\hline 01559795 & Bobs Creek near Pavia, PA & LSUS & Lower Susquehanna River Basin & 40.27258 & -78.59840 & 17 & Undev \\
\hline 02398300 & Chattooga River above Gaylesville, AL & MOBL & Mobile River Basin & 34.29037 & -85.50910 & 366 & Undev \\
\hline 02419977 & Three Mile Branch at Montgomery, AL & MOBL & Mobile River Basin & 32.42236 & -86.25500 & 9 & Urban \\
\hline 02421115 & Pintlalla Creek near Pintlalla, AL & MOBL & Mobile River Basin & 32.15292 & -86.35360 & 59 & Undev \\
\hline 0242354750 & Cahaba Valley Creek at Pelham, AL & MOBL & Mobile River Basin & 33.31345 & -86.80640 & 26 & Mixed \\
\hline 01095220 & Stillwater River near Sterling, MA & NECB & New England Coastal Basins & 42.41093 & -71.79120 & 30 & Mixed \\
\hline 01101500 & Ipswich River at South Middleton, MA & NECB & New England Coastal Basins & 42.56954 & -71.02700 & 45 & Urban \\
\hline 01102345 & Saugus River at Saugus, MA & NECB & New England Coastal Basins & 42.46954 & -71.00730 & 23 & Urban \\
\hline 01105000 & Neponset River at Norwood, MA & NECB & New England Coastal Basins & 42.17760 & -71.20090 & 33 & Urban \\
\hline 01109000 & Wading River near Norton, MA & NECB & New England Coastal Basins & 41.94760 & -71.17670 & 44 & Urban \\
\hline 01112900 & Blackstone River at Manville, RI & NECB & New England Coastal Basins & 41.97121 & -71.47010 & 431 & Mixed \\
\hline 12392155 & Lightning Creek at Clark Fork, ID & NROK & Northern Rockies Intermontane Basins & 48.15104 & -116.18300 & 126 & Undev \\
\hline 12413875 & St. Joe River near Red Ives Work Station, ID & NROK & Northern Rockies Intermontane Basins & 47.05603 & -115.35300 & 106 & Undev \\
\hline 06923150 & Dousinbury Creek near Wall Street, MO & OZRK & Ozark Plateaus & 37.59449 & -92.96690 & 41 & $\mathrm{Ag}$ \\
\hline 06929315 & Paddy Creek above Slabtown Spring, MO & OZRK & Ozark Plateaus & 37.55810 & -92.04880 & 30 & Undev \\
\hline 07053250 & Yocum Creek near Oak Grove, AR & OZRK & Ozark Plateaus & 36.45395 & -93.35660 & 52 & $\mathrm{Ag}$ \\
\hline
\end{tabular}


[Ag, Agriculture; Undev, undeveloped]

\begin{tabular}{|c|c|c|c|c|c|c|c|}
\hline $\begin{array}{l}\text { U.S. Geological } \\
\text { Survey site number }\end{array}$ & Site name & $\begin{array}{l}\text { Study unit } \\
\text { identifier }\end{array}$ & Study unit name & $\begin{array}{l}\text { Latitude } \\
\text { (decimal } \\
\text { degrees) }\end{array}$ & $\begin{array}{l}\text { Longitude } \\
\text { (decimal } \\
\text { degrees) }\end{array}$ & $\begin{array}{c}\text { Drainage } \\
\text { area (square } \\
\text { miles) }\end{array}$ & $\begin{array}{l}\text { Land-use } \\
\text { classification }\end{array}$ \\
\hline 07055646 & Buffalo River near Boxley, AR & OZRK & Ozark Plateaus & 35.94535 & -93.40350 & 59 & Undev \\
\hline 07061600 & Black River Below Annapolis, MO & OZRK & Ozark Plateaus & 37.32505 & -90.76400 & 495 & Undev \\
\hline 07065495 & Jacks Fork River at Alley Spring, MO & OZRK & Ozark Plateaus & 37.14449 & -91.45760 & 305 & Undev \\
\hline 01485000 & Pocomoke River at Willards, MD & PODL & Potomac River Basin (POTO) \& Delmarva Peninsula (DLMV) & 38.38888 & -75.32500 & 53 & $\mathrm{Ag}$ \\
\hline 01493112 & Chesterville Branch near Crumpton, MD & PODL & Potomac River Basin (POTO) \& Delmarva Peninsula (DLMV) & 39.25722 & -75.94056 & 7 & $\mathrm{Ag}$ \\
\hline 01493500 & Morgan Creek near Kennedyville, MD & PODL & Potomac River Basin (РОTO) \& Delmarva Peninsula (DLMV) & 39.28000 & -76.01444 & 13 & Ag \\
\hline 01608000 & South Fork South Branch Potomac River near Moorefield, WV & PODL & Potomac River Basin (POTO) \& Delmarva Peninsula (DLMV) & 39.01233 & -78.95610 & 277 & Undev \\
\hline 01610400 & Waites Run near Wardensville, WV & PODL & Potomac River Basin (POTO) \& Delmarva Peninsula (DLMV) & 39.04270 & -78.59830 & 11 & Undev \\
\hline 01621050 & Muddy Creek at Mount Clinton, VA & PODL & Potomac River Basin (POTO) \& Delmarva Peninsula (DLMV) & 38.48651 & -78.96090 & 14 & $\mathrm{Ag}$ \\
\hline 01638480 & Catoctin Creek at Taylorstown, VA & PODL & Potomac River Basin (POTO) \& Delmarva Peninsula (DLMV) & 39.25510 & -77.57640 & 90 & $\mathrm{Ag}$ \\
\hline 01654000 & Accotink Creek near Annandale, VA & PODL & Potomac River Basin (POTO) \& Delmarva Peninsula (DLMV) & 38.81289 & -77.22830 & 23 & Urban \\
\hline 12056500 & North Fork Skokomish River near Hoodsport, WA & PUGT & Puget Sound Drainages & 47.51426 & -123.33000 & 57 & Undev \\
\hline 12061500 & Skokomish River near Potlatch, WA & PUGT & Puget Sound Drainages & 47.30982 & -123.17700 & 131 & Undev \\
\hline 12108500 & Newaukum Creek near Black Diamond, WA & PUGT & Puget Sound Drainages & 47.27566 & -122.06000 & 27 & Mixed \\
\hline 12112600 & Big Soos Creek near Auburn, WA & PUGT & Puget Sound Drainages & 47.31232 & -122.16500 & 67 & Urban \\
\hline 12113375 & Springbrook Creek at Tukwila, WA & PUGT & Puget Sound Drainages & 47.46565 & -122.23300 & 20 & Urban \\
\hline 12113390 & Duwamish River at Tukwila, WA & PUGT & Puget Sound Drainages & 47.47899 & -122.25900 & 461 & Mixed \\
\hline 12128000 & Thornton Creek near Seattle, WA & PUGT & Puget Sound Drainages & 47.69566 & -122.27600 & 11 & Urban \\
\hline 12212100 & Fishtrap Creek at Lynden, WA & PUGT & Puget Sound Drainages & 48.92650 & -122.49600 & 38 & $\mathrm{Ag}$ \\
\hline 05082625 & Turtle River near Arvilla, ND & REDN & Red River of the North Basin & 47.93832 & -97.50040 & 254 & Ag \\
\hline 11447360 & Arcade Creek near Del Paso Heights, CA & SACR & Sacramento River Basin & 38.64185 & -121.38300 & 31 & Urban \\
\hline 11274538 & Orestimba Creek near Crows Landing, CA & SANJ & San Joaquin-Tulare River Basins & 37.41355 & -121.01600 & 11 & $\mathrm{Ag}$ \\
\hline 021603257 & Brushy Creek near Pelham, SC & SANT & Santee River Basin \& Coastal Drainages & 34.86317 & -82.25070 & 14 & Urban \\
\hline 021607224 & Indian Creek Above Newberry, SC & SANT & Santee River Basin \& Coastal Drainages & 34.42514 & -81.60480 & 63 & Undev \\
\hline 02174250 & Cow Castle Creek near Bowman, SC & SANT & Santee River Basin \& Coastal Drainages & 33.37877 & -80.69980 & 24 & Mixed \\
\hline 08169000 & Comal River at New Braunfels, TX & SCTX & South-Central Texas & 29.70606 & -98.12250 & 132 & Mixed \\
\hline 08171000 & Blanco River at Wimberley, TX & SCTX & South-Central Texas & 29.99438 & -98.08890 & 357 & Undev \\
\hline 08178800 & Salado Creek at San Antonio, TX & SCTX & South-Central Texas & 29.35718 & -98.41280 & 195 & Urban \\
\hline 08195000 & Frio River at Concan, TX & SCTX & South-Central Texas & 29.48856 & -99.70480 & 397 & Undev \\
\hline 11060400 & Warm Creek near San Bernardino, CA & SOCA & Southern California Coastal Drainages & 34.07835 & -117.30000 & 12 & Urban \\
\hline 11073495 & Cucamonga Creek near Mira Loma, CA & SOCA & Southern California Coastal Drainages & 33.98279 & -117.59900 & 80 & Urban \\
\hline 06753400 & Lonetree Creek at Carr, CO & SPLT & South Platte River Basin & 40.89832 & -104.86800 & 169 & Undev \\
\hline 402114105350101 & Big Thompson River near Estes Park, CO & SPLT & South Platte River Basin & 40.35387 & -105.58400 & 40 & Undev \\
\hline 03466208 & Big Limestone Creek near Limestone, TN & TENN & Tennessee River Basin (UTEN \& LTEN) & 36.20594 & -82.65040 & 79 & $\mathrm{Ag}$ \\
\hline 03524550 & Guest River near Miller Yard, VA & TENN & Tennessee River Basin (UTEN \& LTEN) & 36.87872 & -82.40600 & 100 & Mixed \\
\hline 03526000 & Copper Creek near Gate City, VA & TENN & Tennessee River Basin (UTEN \& LTEN) & 36.67399 & -82.56570 & 107 & Mixed \\
\hline 03573182 & Scarham Creek near McVille, AL & TENN & Tennessee River Basin (UTEN \& LTEN) & 34.29843 & -86.11660 & 54 & $\mathrm{Ag}$ \\
\hline 0357479650 & Hester Creek near Plevna, AL & TENN & Tennessee River Basin (UTEN \& LTEN) & 34.96092 & -86.46360 & 29 & $\mathrm{Ag}$ \\
\hline
\end{tabular}


Table 1. Site location, drainage area, and land-use classification.-Continued

[Ag, Agriculture; Undev, undeveloped]

\begin{tabular}{|c|c|c|c|c|c|c|c|}
\hline $\begin{array}{l}\text { U.S. Geological } \\
\text { Survey site number }\end{array}$ & Site name & $\begin{array}{l}\text { Study unit } \\
\text { identifier }\end{array}$ & Study unit name & $\begin{array}{l}\text { Latitude } \\
\text { (decimal } \\
\text { degrees) }\end{array}$ & $\begin{array}{l}\text { Longitude } \\
\text { (decimal } \\
\text { degrees) }\end{array}$ & $\begin{array}{c}\text { Drainage } \\
\text { area (square } \\
\text { miles) }\end{array}$ & $\begin{array}{l}\text { Land-use } \\
\text { classification }\end{array}$ \\
\hline 03575100 & Flint River near Brownsboro, AL & TENN & Tennessee River Basin (UTEN \& LTEN) & 34.74926 & -86.44670 & 374 & $\mathrm{Ag}$ \\
\hline 035825882 & Cane Creek near Howell, TN & TENN & Tennessee River Basin (UTEN \& LTEN) & 35.22286 & -86.62310 & 79 & Mixed \\
\hline 03598250 & North Fork Creek near Poplins Crossroads, TN & TENN & Tennessee River Basin (UTEN \& LTEN) & 35.58507 & -86.59580 & 74 & $\mathrm{Ag}$ \\
\hline 08044000 & Big Sandy Creek near Bridgeport, TX & TRIN & Trinity River Basin & 33.23178 & -97.69480 & 334 & Mixed \\
\hline 08051500 & Clear Creek near Sanger, TX & TRIN & Trinity River Basin & 33.33623 & -97.17950 & 295 & Mixed \\
\hline 08057200 & White Rock Creek at Dallas, TX & TRIN & Trinity River Basin & 32.88917 & -96.75639 & 67 & Mixed \\
\hline 08058900 & East Fork Trinity River at McKinney, TX & TRIN & Trinity River Basin & 33.24400 & -96.60890 & 168 & $\mathrm{Ag}$ \\
\hline 08065800 & Bedias Creek near Madisonville, TX & TRIN & Trinity River Basin & 30.88436 & -95.77770 & 331 & $\mathrm{Ag}$ \\
\hline 08066295 & Menard Creek near Fuqua, TX & TRIN & Trinity River Basin & 30.46187 & -94.72300 & 107 & Undev \\
\hline 09010500 & Colorado River near Grand Lake, CO & UCOL & Upper Colorado River Basin & 40.32582 & -105.85700 & 63 & Undev \\
\hline 09046530 & French Gulch at Breckenridge, $\mathrm{CO}$ & UCOL & Upper Colorado River Basin & 39.49305 & -106.04500 & 11 & Mixed \\
\hline 05531500 & Salt Creek at Western Springs, IL & UIRB & Upper Illinois River Basin & 41.82642 & -87.90010 & 112 & Urban \\
\hline 05548105 & Nippersink Creek above Wonder Lake, IL & UIRB & Upper Illinois River Basin & 42.38530 & -88.36930 & 85 & Mixed \\
\hline 05276005 & North Fork Crow River above Paynesville, MN & UMIS & Upper Mississippi River Basin & 45.37719 & -94.78360 & 232 & $\mathrm{Ag}$ \\
\hline 05288705 & Shingle Creek at Minneapolis, MN & UMIS & Upper Mississippi River Basin & 45.04996 & -93.31020 & 28 & Urban \\
\hline 05320270 & Little Cobb River near Beauford, MN & UMIS & Upper Mississippi River Basin & 43.99663 & -93.90860 & 130 & $\mathrm{Ag}$ \\
\hline 05330902 & Nine Mile Creek at Bloomington, MN & UMIS & Upper Mississippi River Basin & 44.80719 & -93.30160 & 45 & Urban \\
\hline 13092747 & Rock Creek at Twin Falls, ID & USNK & Upper Snake River Basin & 42.56241 & -114.49500 & 241 & $\mathrm{Ag}$ \\
\hline 13120500 & Big Lost River near Chilly, ID & USNK & Upper Snake River Basin & 43.99825 & -114.02100 & 442 & Undev \\
\hline 03267900 & Mad River near Eagle City, OH & WHMI & White, Great (WHIT) \& Little Miami (MIAM) River Basins & 39.96423 & -83.83160 & 310 & $\mathrm{Ag}$ \\
\hline 03353637 & Little Buck Creek near Indianapolis, IN & WHMI & White, Great (WHIT) \& Little Miami (MIAM) River Basins & 39.66671 & -86.19660 & 17 & Mixed \\
\hline 03360895 & Kessinger Ditch near Monroe City, IN & WHMI & White, Great (WHIT) \& Little Miami (MIAM) River Basins & 38.57061 & -87.27700 & 56 & $\mathrm{Ag}$ \\
\hline 03366500 & Muscatatuck River near Deputy, IN & WHMI & White, Great (WHIT) \& Little Miami (MIAM) River Basins & 38.80422 & -85.67390 & 292 & $\mathrm{Ag}$ \\
\hline 03373530 & Lost River near Leipsic, IN & WHMI & White, Great (WHIT) \& Little Miami (MIAM) River Basins & 38.63644 & -86.36530 & 35 & $\mathrm{Ag}$ \\
\hline 391732085414401 & Clifty Creek near Hartsville, IN & WHMI & White, Great (WHIT) \& Little Miami (MIAM) River Basins & 39.29227 & -85.69550 & 88 & $\mathrm{Ag}$ \\
\hline 393944084120700 & Holes Creek at Kettering, $\mathrm{OH}$ & WHMI & White, Great (WHIT) \& Little Miami (MIAM) River Basins & 39.66228 & -84.20190 & 20 & Mixed \\
\hline 394340085524601 & Sugar Creek at New Palestine, IN & WHMI & White, Great (WHIT) \& Little Miami (MIAM) River Basins & 39.72782 & -85.87940 & 95 & $\mathrm{Ag}$ \\
\hline 14200400 & Little Abiqua Creek near Scotts Mills, OR & WILL & Willamette Basin & 44.95568 & -122.62800 & 10 & Undev \\
\hline 14201300 & Zollner Creek near Mt. Angel, OR & WILL & Willamette Basin & 45.10040 & -122.82200 & 15 & $\mathrm{Ag}$ \\
\hline 14205400 & East Fork Dairy Creek near Meachan Corner, OR & WILL & Willamette Basin & 45.66667 & -123.07000 & 34 & Undev \\
\hline 14206950 & Fanno Creek at Durham, OR & WILL & Willamette Basin & 45.40345 & -122.75500 & 31 & Urban \\
\hline 04063700 & Popple River near Fence, WI & WMIC & Western Lake Michigan Drainages & 45.76357 & -88.46320 & 140 & Undev \\
\hline 04072050 & Duck Creek near Howard, WI & WMIC & Western Lake Michigan Drainages & 44.46582 & -88.21900 & 95 & $\mathrm{Ag}$ \\
\hline 040869415 & Lincoln Creek at Milwaukee, WI & WMIC & Western Lake Michigan Drainages & 43.09695 & -87.97230 & 10 & Urban \\
\hline 06187915 & Soda Butte Creek near Silvergate, MT & YELL & Yellowstone River Basin & 45.00299 & -110.00200 & 28 & Undev \\
\hline 06298000 & Tongue River near Dayton, WY & YELL & Yellowstone River Basin & 44.84941 & -107.30500 & 206 & Undev \\
\hline
\end{tabular}




\begin{tabular}{|c|c|c|c|c|c|c|c|c|c|c|}
\hline \multirow[b]{2}{*}{$\begin{array}{l}\text { U.S. Geological } \\
\text { Survey site number }\end{array}$} & \multirow[b]{2}{*}{ Site name } & \multirow[b]{2}{*}{$\begin{array}{l}\text { Study unit } \\
\text { identifier }\end{array}$} & \multicolumn{4}{|c|}{ Longer-term period } & \multicolumn{4}{|c|}{ Load-simulation period } \\
\hline & & & $\begin{array}{l}\text { Base-flow } \\
\text { index }\end{array}$ & $\begin{array}{l}\text { First } \\
\text { water } \\
\text { year }\end{array}$ & $\begin{array}{l}\text { Last } \\
\text { water } \\
\text { year }\end{array}$ & $\begin{array}{l}\text { Number } \\
\text { of years }\end{array}$ & $\begin{array}{l}\text { Base-flow } \\
\text { index }\end{array}$ & $\begin{array}{c}\text { First } \\
\text { water year }\end{array}$ & $\begin{array}{c}\text { Last } \\
\text { water year }\end{array}$ & $\begin{array}{l}\text { Number } \\
\text { of years }\end{array}$ \\
\hline site & site_name & suid & bfi & first_wy & last_wy & n_years & bfi_sim & fsim_wy & Isim_wy & n_years_sim \\
\hline 07375050 & Tchefuncte River near Covington, LA & ACAD & 0.55 & 2000 & 2001 & 2 & 0.55 & 2000 & 2001 & 2 \\
\hline 08010000 & Bayou Des Cannes near Eunice, LA & ACAD & .09 & 1990 & 2006 & 17 & .07 & 1999 & 2001 & 3 \\
\hline 02332830 & West Fork Little River near Clermont, GA & ACFB & .65 & 1994 & 1998 & 5 & .65 & 1994 & 1998 & 5 \\
\hline 02335870 & Sope Creek near Marietta, GA & ACFB & .38 & 1990 & 2006 & 17 & .37 & 1993 & 2005 & 13 \\
\hline 02336300 & Peachtree Creek at Atlanta, GA & ACFB & .27 & 1990 & 2006 & 17 & .27 & 1993 & 2005 & 13 \\
\hline 02337500 & Snake Creek near Whitesburg, GA & ACFB & .67 & 1990 & 2006 & 17 & .67 & 1993 & 2001 & 9 \\
\hline 02338523 & Hillibahatchee Creek near Franklin, GA & ACFB & .69 & 2003 & 2006 & 4 & .65 & 2003 & 2005 & 3 \\
\hline 02350080 & Lime Creek near Cobb, GA & ACFB & .50 & 1994 & 2006 & 7 & .48 & 1994 & 2005 & 6 \\
\hline 02084160 & Chicod Creek near Simpson, NC & ALBE & .25 & 1993 & 2006 & 14 & .32 & 1993 & 1997 & 5 \\
\hline 02084557 & Van Swamp near Hoke, NC & ALBE & .43 & 1990 & 2006 & 17 & .43 & 1993 & 2004 & 12 \\
\hline 0208925200 & Bear Creek at Mays Store, $\mathrm{NC}$ & ALBE & .52 & 1990 & 2006 & 17 & .51 & 1993 & 2001 & 9 \\
\hline 03015795 & East Hickory Creek near Queen, PA & ALMN & .47 & 1997 & 1998 & 2 & .47 & 1997 & 1998 & 2 \\
\hline 03037350 & South Branch Plum Creek at Five Points, PA & ALMN & .32 & 1997 & 1998 & 2 & .32 & 1997 & 1998 & 2 \\
\hline 03040000 & Stonycreek River at Ferndale, PA & ALMN & .49 & 1990 & 2006 & 17 & .47 & 1996 & 1998 & 3 \\
\hline 03049646 & Deer Creek near Dorseyville, PA & ALMN & .39 & 1997 & 1998 & 2 & .39 & 1997 & 1998 & 2 \\
\hline 03072000 & Dunkard Creek at Shannopin, PA & ALMN & .31 & 1990 & 2006 & 17 & .30 & 1996 & 1998 & 3 \\
\hline 09505800 & West Clear Creek near Camp Verde, AZ & CAZB & .59 & 1990 & 2006 & 17 & .61 & 2001 & 2005 & 5 \\
\hline 12464770 & Crab Creek near Ritzville, WA & CCYK & .81 & 1994 & 2004 & 9 & .81 & 1994 & 2004 & 9 \\
\hline 06773050 & Prairie Creek near Ovina, NE & CNBR & .43 & 1994 & 1999 & 3 & .58 & 1994 & 1994 & 1 \\
\hline 06775900 & Dismal River near Thedford, NE & CNBR & .97 & 1990 & 2006 & 17 & .97 & 1990 & 2004 & 15 \\
\hline 06795500 & Shell Creek near Columbus, NE & CNBR & .43 & 1990 & 2006 & 17 & .40 & 1992 & 1995 & 4 \\
\hline 06800000 & Maple Creek near Nickerson, NE & CNBR & .46 & 1990 & 2006 & 17 & .45 & 1990 & 2005 & 16 \\
\hline 01135300 & Sleepers River near St. Johnsbury, VT & CONN & .49 & 1990 & 2006 & 17 & .52 & 1993 & 1995 & 3 \\
\hline 01137500 & Ammonoosuc River at Bethlehem Junction, NH & CONN & .49 & 1990 & 2006 & 17 & .56 & 1993 & 1995 & 3 \\
\hline 01170100 & Green River near Colrain, MA & CONN & .49 & 1990 & 2006 & 17 & .48 & 1993 & 2005 & 13 \\
\hline 01199900 & Tenmile River near Wingdale, NY & CONN & .58 & 1992 & 2006 & 15 & .61 & 1993 & 1995 & 3 \\
\hline 01208873 & Rooster River at Fairfield, CT & CONN & .45 & 1990 & 2005 & 16 & .49 & 1993 & 1995 & 3 \\
\hline 01209710 & Norwalk River at Winnipauk,CT & CONN & .49 & 1990 & 2005 & 16 & .49 & 1990 & 2005 & 16 \\
\hline 01451800 & Jordon Creek near Schnecksville, PA & DELR & .39 & 1990 & 2006 & 17 & .43 & 1999 & 2001 & 3 \\
\hline 01464907 & Little Neshaminy Creek near Warminster, PA & DELR & .25 & 2000 & 2006 & 7 & .25 & 2000 & 2004 & 5 \\
\hline 01467150 & Cooper River at Haddonfield, NJ & DELR & .43 & 1990 & 2006 & 17 & .40 & 1999 & 2005 & 7 \\
\hline 01470779 & Tulpehocken Creek near Bernville, PA & DELR & .72 & 1990 & 2006 & 17 & .73 & 1999 & 2001 & 3 \\
\hline 01472157 & French Creek near Phoenixville, PA & DELR & .55 & 1990 & 2006 & 17 & .54 & 1999 & 2005 & 7 \\
\hline 01477120 & Racoon Creek near Swedesboro, NJ & DELR & .63 & 1990 & 2006 & 17 & .63 & 1999 & 2005 & 7 \\
\hline 02215100 & Tucsawhatchee Creek near Hawkinsville, GA & GAFL & .46 & 1990 & 2006 & 17 & .45 & 1993 & 1996 & 4 \\
\hline 02300700 & Bullfrog Creek near Wimauma, FL & GAFL & .29 & 1990 & 2006 & 17 & .33 & 1993 & 1996 & 4 \\
\hline
\end{tabular}


Table 2. Comparison of longer-term base-flow index to load-simulation period base-flow index.-Continued

\begin{tabular}{|c|c|c|c|c|c|c|c|c|c|c|}
\hline \multirow[b]{2}{*}{$\begin{array}{l}\text { U.S. Geological } \\
\text { Survey site number }\end{array}$} & \multirow[b]{2}{*}{ Site name } & \multirow[b]{2}{*}{$\begin{array}{l}\text { Study unit } \\
\text { identifier }\end{array}$} & \multicolumn{4}{|c|}{ Longer-term period } & \multicolumn{4}{|c|}{ Load-simulation period } \\
\hline & & & $\begin{array}{l}\text { Base-flow } \\
\text { index }\end{array}$ & $\begin{array}{c}\text { First } \\
\text { water } \\
\text { year }\end{array}$ & $\begin{array}{l}\text { Last } \\
\text { water } \\
\text { year }\end{array}$ & $\begin{array}{l}\text { Number } \\
\text { of years }\end{array}$ & $\begin{array}{l}\text { Base-flow } \\
\text { index }\end{array}$ & $\begin{array}{c}\text { First } \\
\text { water year }\end{array}$ & $\begin{array}{l}\text { Last } \\
\text { water year }\end{array}$ & $\begin{array}{l}\text { Number } \\
\text { of years }\end{array}$ \\
\hline 02306774 & Rocky Creek near Citrus Park, FL & GAFL & 0.34 & 1990 & 2006 & 17 & 0.39 & 2002 & 2005 & 4 \\
\hline 02317797 & Little River near Tifton, GA & GAFL & .29 & 1994 & 1997 & 4 & .29 & 1994 & 1997 & 4 \\
\hline 10102200 & Cub River near Richmond, UT & GRSL & .73 & 1999 & 2000 & 2 & .73 & 1999 & 2000 & 2 \\
\hline 10167800 & Little Cottonwood Creek at Crestwood Park, UT & GRSL & .27 & 1990 & 2001 & 4 & .15 & 1999 & 2000 & 2 \\
\hline 10168000 & Little Cottonwood Creek at Salt Lake City, UT & GRSL & .36 & 1990 & 2006 & 9 & .32 & 1999 & 2005 & 7 \\
\hline 10172200 & Red Butte Creek at Fort Douglas, UT & GRSL & .89 & 1990 & 2006 & 17 & .89 & 1990 & 2005 & 16 \\
\hline 01356190 & Lisha Kill northwest of Niskayuna, NY & HDSN & .38 & 1994 & 2005 & 9 & .38 & 1994 & 2005 & 9 \\
\hline 01362200 & Esopus Creek at Allaben, NY & HDSN & .46 & 1990 & 2006 & 17 & .47 & 1993 & 2004 & 12 \\
\hline 01372051 & Fall Kill at Poughkeepsie, NY & HDSN & .53 & 1994 & 1995 & 2 & .53 & 1994 & 1995 & 2 \\
\hline 03167000 & Reed Creek at Grahams Forge, VA & KANA & .59 & 1990 & 2006 & 17 & .61 & 1997 & 1998 & 2 \\
\hline 03170000 & Little River at Graysontown, VA & KANA & .67 & 1990 & 2006 & 17 & .68 & 1997 & 1998 & 2 \\
\hline 03178000 & Bluestone River near Spanishburg, WV & KANA & .45 & 1997 & 1998 & 2 & .45 & 1997 & 1998 & 2 \\
\hline 03191500 & Peters Creek near Lockwood, WV & KANA & .40 & 1997 & 2006 & 5 & .42 & 1997 & 1998 & 2 \\
\hline 04159492 & Black River near Jeddo, MI & LERI & .29 & 1990 & 2006 & 17 & .27 & 1996 & 1998 & 3 \\
\hline 04186500 & Auglaize River near Fort Jennings, OH & LERI & .18 & 1990 & 2006 & 17 & .17 & 1996 & 2005 & 10 \\
\hline 04213500 & Cattaraugus Creek at Gowanda, NY & LERI & .48 & 1990 & 2006 & 16 & .47 & 1990 & 1998 & 9 \\
\hline 01390500 & Saddle River at Ridgewood, NJ & LINJ & .51 & 1990 & 2005 & 16 & .53 & 1996 & 1998 & 3 \\
\hline 01398000 & Neshanic River at Reaville, NJ & LINJ & .24 & 1990 & 2006 & 17 & .24 & 1991 & 2005 & 15 \\
\hline 01403900 & Bound Brook at Middlesex, NJ & LINJ & .32 & 1997 & 2006 & 4 & .28 & 1997 & 1998 & 2 \\
\hline 01410784 & Great Egg Harbor River near Sicklerville, NJ & LINJ & .58 & 1997 & 1998 & 2 & .58 & 1997 & 1998 & 2 \\
\hline 05568800 & Indian Creek near Wyoming, IL & LIRB & .49 & 1990 & 2006 & 17 & .47 & 1997 & 1998 & 2 \\
\hline 01555400 & East Mahantango Creek at Klingerstown, PA & LSUS & .36 & 1993 & 2000 & 6 & .36 & 1993 & 2000 & 6 \\
\hline 01559795 & Bobs Creek near Pavia, PA & LSUS & .41 & 1994 & 2000 & 4 & .41 & 1994 & 2000 & 4 \\
\hline 02398300 & Chattooga River above Gaylesville, AL & MOBL & .54 & 1990 & 2006 & 17 & .58 & 1999 & 2001 & 3 \\
\hline 02419977 & Three Mile Branch at Montgomery, AL & MOBL & .30 & 1999 & 2001 & 3 & .30 & 1999 & 2001 & 3 \\
\hline 02421115 & Pintlalla Creek near Pintlalla, AL & MOBL & .16 & 1999 & 2001 & 3 & 16 & 1999 & 2001 & 3 \\
\hline 0242354750 & Cahaba Valley Creek at Pelham, AL & MOBL & .41 & 1999 & 2006 & 8 & .40 & 1999 & 2005 & 7 \\
\hline 01095220 & Stillwater River near Sterling, MA & NECB & .48 & 1995 & 2006 & 12 & .49 & 1999 & 2004 & 6 \\
\hline 01101500 & Ipswich River at South Middleton, MA & NECB & .55 & 1990 & 2006 & 17 & .49 & 1999 & 2004 & 6 \\
\hline 01102345 & Saugus River at Saugus, MA & NECB & .48 & 1995 & 2006 & 12 & .47 & 1999 & 2004 & 6 \\
\hline 01105000 & Neponset River at Norwood, MA & NECB & .57 & 1990 & 2006 & 17 & .53 & 1999 & 2004 & 6 \\
\hline 01109000 & Wading River near Norton, MA & NECB & .59 & 1990 & 2006 & 17 & .58 & 1999 & 2004 & 6 \\
\hline 01112900 & Blackstone River at Manville, RI & NECB & .62 & 1990 & 2006 & 17 & .62 & 1993 & 2002 & 10 \\
\hline 12392155 & Lightning Creek at Clark Fork, ID & NROK & .53 & 1990 & 2006 & 16 & .60 & 1999 & 2001 & 3 \\
\hline 12413875 & St. Joe River near Red Ives Work Station, ID & NROK & .75 & 1999 & 2006 & 8 & .76 & 1999 & 2005 & 7 \\
\hline 06923150 & Dousinbury Creek near Wall Street, MO & OZRK & .26 & 1994 & 1997 & 4 & .26 & 1994 & 1997 & 4 \\
\hline 06929315 & Paddy Creek above Slabtown Spring, MO & OZRK & .21 & 1994 & 1997 & 4 & .21 & 1994 & 1997 & 4 \\
\hline 07053250 & Yocum Creek near Oak Grove, AR & OZRK & .43 & 1994 & 2006 & 13 & .43 & 1994 & 2005 & 12 \\
\hline
\end{tabular}




\begin{tabular}{|c|c|c|c|c|c|c|c|c|c|c|}
\hline \multirow[b]{2}{*}{$\begin{array}{c}\text { U.S. Geological } \\
\text { Survey site number }\end{array}$} & \multirow[b]{2}{*}{ Site name } & \multirow[b]{2}{*}{$\begin{array}{l}\text { Study unit } \\
\text { identifier }\end{array}$} & \multicolumn{4}{|c|}{ Longer-term period } & \multicolumn{4}{|c|}{ Load-simulation period } \\
\hline & & & $\begin{array}{l}\text { Base-flow } \\
\text { index }\end{array}$ & $\begin{array}{c}\text { First } \\
\text { water } \\
\text { year }\end{array}$ & $\begin{array}{c}\text { Last } \\
\text { water } \\
\text { year }\end{array}$ & $\begin{array}{l}\text { Number } \\
\text { of years }\end{array}$ & $\begin{array}{l}\text { Base-flow } \\
\text { index }\end{array}$ & $\begin{array}{c}\text { First } \\
\text { water year }\end{array}$ & $\begin{array}{c}\text { Last } \\
\text { water year }\end{array}$ & $\begin{array}{l}\text { Number } \\
\text { of years }\end{array}$ \\
\hline 07055646 & Buffalo River near Boxley, AR & OZRK & 0.25 & 1994 & 2006 & 10 & 0.23 & 1994 & 2004 & 8 \\
\hline 07061600 & Black River Below Annapolis, MO & OZRK & .50 & 1990 & 2006 & 17 & .50 & 1993 & 2005 & 13 \\
\hline 07065495 & Jacks Fork River at Alley Spring, MO & OZRK & .47 & 1994 & 2006 & 13 & .48 & 1994 & 1997 & 4 \\
\hline 01485000 & Pocomoke River at Willards, MD & PODL & .51 & 1990 & 2004 & 15 & .55 & 1999 & 2002 & 4 \\
\hline 01493112 & Chesterville Branch near Crumpton, MD & PODL & .71 & 1997 & 2002 & 6 & .70 & 1999 & 2002 & 4 \\
\hline 01493500 & Morgan Creek near Kennedyville, MD & PODL & .53 & 1990 & 2005 & 16 & .52 & 1998 & 2004 & 7 \\
\hline 01608000 & South Fork South Branch Potomac River near Moorefield, WV & PODL & .39 & 1990 & 2006 & 17 & .36 & 1993 & 1995 & 3 \\
\hline 01610400 & Waites Run near Wardensville, WV & PODL & .47 & 2003 & 2006 & 4 & .49 & 2003 & 2005 & 3 \\
\hline 01621050 & Muddy Creek at Mount Clinton, VA & PODL & .55 & 1994 & 2006 & 13 & .53 & 1994 & 2002 & 9 \\
\hline 01638480 & Catoctin Creek at Taylorstown, VA & PODL & .44 & 1990 & 2006 & 17 & .45 & 1993 & 1995 & 3 \\
\hline 01654000 & Accotink Creek near Annandale, VA & PODL & .22 & 1990 & 2006 & 17 & .22 & 1993 & 2002 & 10 \\
\hline 12056500 & North Fork Skokomish River near Hoodsport, WA & PUGT & .54 & 1990 & 2006 & 17 & .52 & 2001 & 2005 & 5 \\
\hline 12061500 & Skokomish River near Potlatch, WA & PUGT & .47 & 1990 & 2006 & 17 & .45 & 1996 & 1998 & 3 \\
\hline 12108500 & Newaukum Creek near Black Diamond, WA & PUGT & .63 & 1990 & 2006 & 17 & .57 & 1996 & 1998 & 3 \\
\hline 12112600 & Big Soos Creek near Auburn, WA & PUGT & .72 & 1990 & 2006 & 17 & .68 & 1996 & 1998 & 3 \\
\hline 12113375 & Springbrook Creek at Tukwila, WA & PUGT & .39 & 1996 & 2004 & 7 & .38 & 1996 & 1998 & 3 \\
\hline 12113390 & Duwamish River at Tukwila, WA & PUGT & .63 & 1990 & 2006 & 17 & .64 & 1996 & 2004 & 9 \\
\hline 12128000 & Thornton Creek near Seattle, WA & PUGT & .60 & 1997 & 2006 & 10 & .61 & 1997 & 2005 & 9 \\
\hline 12212100 & Fishtrap Creek at Lynden, WA & PUGT & .60 & 1997 & 1998 & 2 & .60 & 1997 & 1998 & 2 \\
\hline 05082625 & Turtle River near Arvilla, ND & REDN & .41 & 1993 & 2006 & 14 & .36 & 1993 & 2000 & 8 \\
\hline 11447360 & Arcade Creek near Del Paso Heights, CA & SACR & .08 & 1997 & 2006 & 10 & .08 & 1997 & 2005 & 9 \\
\hline 11274538 & Orestimba Creek near Crows Landing, CA & SANJ & .28 & 1993 & 2006 & 14 & .29 & 1993 & 2005 & 13 \\
\hline 021603257 & Brushy Creek near Pelham, SC & SANT & .55 & 1996 & 1997 & 2 & .55 & 1996 & 1997 & 2 \\
\hline 021607224 & Indian Creek Above Newberry, SC & SANT & .35 & 1996 & 1998 & 3 & .35 & 1996 & 1998 & 3 \\
\hline 02174250 & Cow Castle Creek near Bowman, SC & SANT & .47 & 1996 & 2006 & 11 & .46 & 1996 & 2005 & 10 \\
\hline 08169000 & Comal River at New Braunfels, TX & SCTX & .94 & 1990 & 2006 & 17 & .98 & 1996 & 1998 & 3 \\
\hline 08171000 & Blanco River at Wimberley, TX & SCTX & .61 & 1990 & 2006 & 17 & .62 & 1996 & 1998 & 3 \\
\hline 08178800 & Salado Creek at San Antonio, TX & SCTX & .24 & 1990 & 2006 & 17 & .24 & 1990 & 2005 & 16 \\
\hline 08195000 & Frio River at Concan, TX & SCTX & .70 & 1990 & 2006 & 17 & .69 & 1993 & 2004 & 12 \\
\hline 11060400 & Warm Creek near San Bernardino, CA & SOCA & .28 & 1990 & 2006 & 17 & .27 & 1999 & 2004 & 6 \\
\hline 11073495 & Cucamonga Creek near Mira Loma, CA & SOCA & .61 & 1990 & 2006 & 17 & .69 & 1999 & 2001 & 3 \\
\hline 06753400 & Lonetree Creek at Carr, CO & SPLT & .77 & 1994 & 1995 & 2 & .77 & 1994 & 1995 & 2 \\
\hline 402114105350101 & Big Thompson River near Estes Park, CO & SPLT & .68 & 1996 & 2006 & 6 & .69 & 1996 & 2004 & 5 \\
\hline 03466208 & Big Limestone Creek near Limestone, TN & TENN & .73 & 1997 & 2005 & 8 & .72 & 1997 & 2004 & 7 \\
\hline 03524550 & Guest River near Miller Yard, VA & TENN & .42 & 1997 & 1998 & 2 & .42 & 1997 & 1998 & 2 \\
\hline 03526000 & Copper Creek near Gate City, VA & TENN & .50 & 1997 & 1998 & 2 & .50 & 1997 & 1998 & 2 \\
\hline 03573182 & Scarham Creek near McVille, AL & TENN & .37 & 1999 & 2003 & 5 & .35 & 1999 & 2001 & 3 \\
\hline
\end{tabular}


Table 2. Comparison of longer-term base-flow index to load-simulation period base-flow index.-Continued

\begin{tabular}{|c|c|c|c|c|c|c|c|c|c|c|}
\hline \multirow[b]{2}{*}{$\begin{array}{l}\text { U.S. Geological } \\
\text { Survey site number }\end{array}$} & \multirow[b]{2}{*}{ Site name } & \multirow[b]{2}{*}{$\begin{array}{l}\text { Study unit } \\
\text { identifier }\end{array}$} & \multicolumn{4}{|c|}{ Longer-term period } & \multicolumn{4}{|c|}{ Load-simulation period } \\
\hline & & & $\begin{array}{l}\text { Base-flow } \\
\text { index }\end{array}$ & $\begin{array}{c}\text { First } \\
\text { water } \\
\text { year }\end{array}$ & $\begin{array}{c}\text { Last } \\
\text { water } \\
\text { year }\end{array}$ & $\begin{array}{l}\text { Number } \\
\text { of years }\end{array}$ & $\begin{array}{l}\text { Base-flow } \\
\text { index }\end{array}$ & $\begin{array}{c}\text { First } \\
\text { water year }\end{array}$ & $\begin{array}{c}\text { Last } \\
\text { water year }\end{array}$ & $\begin{array}{l}\text { Number } \\
\text { of years }\end{array}$ \\
\hline 0357479650 & Hester Creek near Plevna, AL & TENN & 0.25 & 1999 & 2005 & 7 & 0.25 & 1999 & 2004 & 6 \\
\hline 03575100 & Flint River near Brownsboro, AL & TENN & .43 & 1999 & 2006 & 8 & .41 & 1999 & 2004 & 6 \\
\hline 035825882 & Cane Creek near Howell, TN & TENN & .20 & 1999 & 2001 & 3 & .20 & 1999 & 2001 & 3 \\
\hline 03598250 & North Fork Creek near Poplins Crossroads, TN & TENN & .18 & 1999 & 2005 & 7 & .19 & 1999 & 2001 & 3 \\
\hline 08044000 & Big Sandy Creek near Bridgeport, TX & TRIN & .24 & 1990 & 2006 & 10 & .23 & 1993 & 1995 & 3 \\
\hline 08051500 & Clear Creek near Sanger, TX & TRIN & .23 & 1990 & 2006 & 17 & .24 & 1993 & 2005 & 13 \\
\hline 08057200 & White Rock Creek at Dallas, TX & TRIN & .23 & 1990 & 2006 & 17 & .26 & 1995 & 2005 & 11 \\
\hline 08058900 & East Fork Trinity River at McKinney, TX & TRIN & .21 & 1990 & 2006 & 17 & .21 & 1993 & 1995 & 3 \\
\hline 08065800 & Bedias Creek near Madisonville, TX & TRIN & .05 & 1990 & 2006 & 17 & .04 & 1993 & 1995 & 3 \\
\hline 08066295 & Menard Creek near Fuqua, TX & TRIN & .35 & 1993 & 1995 & 3 & .35 & 1993 & 1995 & 3 \\
\hline 09010500 & Colorado River near Grand Lake, CO & UCOL & .67 & 1990 & 2006 & 17 & .65 & 1995 & 1998 & 4 \\
\hline 09046530 & French Gulch at Breckenridge, CO & UCOL & .75 & 1996 & 2003 & 8 & .74 & 1996 & 1999 & 4 \\
\hline 05531500 & Salt Creek at Western Springs, IL & UIRB & .46 & 1990 & 2006 & 17 & .46 & 1999 & 2006 & 8 \\
\hline 05548105 & Nippersink Creek above Wonder Lake, IL & UIRB & .54 & 1995 & 2001 & 6 & .51 & 1999 & 2001 & 3 \\
\hline 05276005 & North Fork Crow River above Paynesville, MN & UMIS & .39 & 1997 & 1998 & 2 & .39 & 1997 & 1998 & 2 \\
\hline 05288705 & Shingle Creek at Minneapolis, MN & UMIS & .38 & 1997 & 2006 & 7 & .37 & 1997 & 2005 & 6 \\
\hline 05320270 & Little Cobb River near Beauford, MN & UMIS & .37 & 1997 & 2006 & 8 & .37 & 1997 & 2005 & 7 \\
\hline 05330902 & Nine Mile Creek at Bloomington, MN & UMIS & .31 & 1997 & 1998 & 2 & .31 & 1997 & 1998 & 2 \\
\hline 13092747 & Rock Creek at Twin Falls, ID & USNK & .88 & 1993 & 2006 & 14 & .88 & 1993 & 2005 & 13 \\
\hline 13120500 & Big Lost River near Chilly, ID & USNK & .72 & 1990 & 2006 & 17 & .74 & 1993 & 1996 & 4 \\
\hline 03267900 & Mad River near Eagle City, OH & WHMI & .68 & 1990 & 2006 & 14 & .67 & 1999 & 2005 & 7 \\
\hline 03353637 & Little Buck Creek near Indianapolis, IN & WHMI & .23 & 1990 & 2006 & 17 & .22 & 1990 & 2004 & 15 \\
\hline 03360895 & Kessinger Ditch near Monroe City, IN & WHMI & .19 & 1993 & 1998 & 6 & .18 & 1993 & 1995 & 3 \\
\hline 03366500 & Muscatatuck River near Deputy, IN & WHMI & .19 & 1990 & 2006 & 17 & .18 & 1993 & 1995 & 3 \\
\hline 03373530 & Lost River near Leipsic, IN & WHMI & .32 & 1993 & 2001 & 9 & .31 & 1993 & 1995 & 3 \\
\hline 391732085414401 & Clifty Creek near Hartsville, IN & WHMI & .27 & 1990 & 2006 & 17 & .29 & 1993 & 1995 & 3 \\
\hline 393944084120700 & Holes Creek at Kettering, $\mathrm{OH}$ & WHMI & .19 & 2000 & 2004 & 5 & .19 & 2000 & 2004 & 5 \\
\hline 394340085524601 & Sugar Creek at New Palestine, IN & WHMI & .32 & 1990 & 2006 & 17 & .32 & 1992 & 2005 & 14 \\
\hline 14200400 & Little Abiqua Creek near Scotts Mills, OR & WILL & .51 & 1994 & 2004 & 11 & .51 & 1994 & 2004 & 11 \\
\hline 14201300 & Zollner Creek near Mt. Angel, OR & WILL & .31 & 1994 & 2006 & 13 & .31 & 1994 & 2005 & 12 \\
\hline 14205400 & East Fork Dairy Creek near Meachan Corner, OR & WILL & .61 & 2003 & 2006 & 4 & .63 & 2003 & 2005 & 3 \\
\hline 14206950 & Fanno Creek at Durham, OR & WILL & .32 & 1994 & 2006 & 8 & .32 & 1994 & 2005 & 7 \\
\hline 04063700 & Popple River near Fence, WI & WMIC & .61 & 1990 & 2006 & 17 & .61 & 1990 & 2005 & 16 \\
\hline 04072050 & Duck Creek near Howard, WI & WMIC & .22 & 1990 & 2006 & 17 & .23 & 1993 & 2005 & 13 \\
\hline 040869415 & Lincoln Creek at Milwaukee, WI & WMIC & .27 & 1994 & 1994 & 1 & .27 & 1994 & 1994 & 1 \\
\hline 06187915 & Soda Butte Creek near Silvergate, MT & YELL & .58 & 1999 & 2006 & 8 & .68 & 1999 & 2001 & 3 \\
\hline 06298000 & Tongue River near Dayton, WY & YELL & .70 & 1990 & 2006 & 17 & .65 & 1999 & 2002 & 4 \\
\hline
\end{tabular}


Table 3. Description of hydrologic landscape regions.

\begin{tabular}{cl}
\hline $\begin{array}{c}\text { Hydrologic } \\
\text { landscape } \\
\text { region }\end{array}$ & Description \\
\hline 1 & Subhumid plains with permeable soils and bedrock \\
2 & Humid plains with permeable soils and bedrock \\
3 & Subhumid plains with impermeable soils and permeable bedrock \\
4 & Humid plains with permeable soils and bedrock \\
5 & Arid plains with permeable soils and bedrock \\
6 & Subhumid plains with impermeable soils and bedrock \\
7 & Humid plains with permeable soils and impermeable bedrock \\
8 & Semiarid plains with impermeable soils and bedrock \\
9 & Humid plateaus with impermeable soils and permeable bedrock \\
10 & Arid plateaus with impermeable soils and permeable bedrock \\
11 & Humid plateaus with impermeable soils and bedrock \\
12 & Semiarid plateaus with permeable soils and impermeable bedrock \\
13 & Semiarid plateaus with impermeable soils and bedrock \\
14 & Arid playas with permeable soils and bedrock \\
15 & Semiarid mountains with impermeable soils and permeable bedrock \\
16 & Humid mountains with permeable soils and impermeable bedrock \\
17 & Semiarid mountains with impermeable soils and bedrock \\
18 & Semiarid mountains with permeable soils and impermeable bedrock \\
19 & Very humid mountains with permeable soils and impermeable bedrock \\
20 & Humid mountains with permeable soils and impermeable bedrock \\
\hline & \\
\hline 1 & \\
\hline &
\end{tabular}


Table 4. Nitrate load ratios and hydrologic landscape regions.

[Water year, the continuous 12-month period, October 1 through September 3. The water year is designated by the calendar year in which it ends and which includes 9 of the 12 months. Thus, the year ending September 30, 1980, is referred to as water year 1980.]

\begin{tabular}{|c|c|c|c|c|c|c|c|c|c|}
\hline $\begin{array}{l}\text { U.S. Geological } \\
\text { Survey site } \\
\text { number }\end{array}$ & Site name & $\begin{array}{c}\text { Study } \\
\text { unit } \\
\text { identifier }\end{array}$ & $\begin{array}{l}\text { First water } \\
\text { year of load } \\
\text { simulation }\end{array}$ & $\begin{array}{l}\text { Last water } \\
\text { year of load } \\
\text { simulation }\end{array}$ & $\begin{array}{l}\text { Number of } \\
\text { years of load } \\
\text { simulation }\end{array}$ & $\begin{array}{l}\text { Base- } \\
\text { flow } \\
\text { index }\end{array}$ & $\begin{array}{l}\text { Nitrate } \\
\text { load } \\
\text { ratio }\end{array}$ & $\begin{array}{c}\text { Dominant } \\
\text { hydrologic } \\
\text { landscape } \\
\text { region } \\
\text { (table 3) }\end{array}$ & $\begin{array}{l}\text { Hydrologic landscape } \\
\text { region category }\end{array}$ \\
\hline site & site_name & suid & fsim_wy & Isim_wy & n_years_sim & bfi_sim & load_ratio & hlr_dom & hlr_category \\
\hline 07375050 & Tchefuncte River near Covington, LA & ACAD & 2000 & 2001 & 2 & 0.55 & 52 & 4 & Permeable soils and permeable bedrock \\
\hline 08010000 & Bayou Des Cannes near Eunice, LA & ACAD & 1999 & 2001 & 3 & .07 & 30 & 6 & Impermeable soils and impermeable bedrock \\
\hline 02332830 & West Fork Little River near Clermont, GA & ACFB & 1994 & 1998 & 5 & .65 & 76 & 16 & Permeable soils and impermeable bedrock \\
\hline 02335870 & Sope Creek near Marietta, GA & ACFB & 1993 & 2005 & 13 & .37 & 41 & 16 & Permeable soils and impermeable bedrock \\
\hline 02336300 & Peachtree Creek at Atlanta, GA & ACFB & 1993 & 2005 & 13 & .27 & 33 & 16 & Permeable soils and impermeable bedrock \\
\hline 02337500 & Snake Creek near Whitesburg, GA & ACFB & 1993 & 2001 & 9 & .67 & 62 & 16 & Permeable soils and impermeable bedrock \\
\hline 02338523 & Hillibahatchee Creek near Franklin, GA & ACFB & 2003 & 2005 & 3 & .65 & 52 & 16 & Permeable soils and impermeable bedrock \\
\hline 02350080 & Lime Creek near Cobb, GA & ACFB & 1994 & 2005 & 6 & .48 & 39 & 2 & Permeable soils and permeable bedrock \\
\hline 02084160 & Chicod Creek near Simpson, NC & ALBE & 1993 & 1997 & 5 & .32 & 26 & 4 & Permeable soils and permeable bedrock \\
\hline 02084557 & Van Swamp near Hoke, NC & ALBE & 1993 & 2004 & 12 & .43 & 31 & 4 & Permeable soils and permeable bedrock \\
\hline 0208925200 & Bear Creek at Mays Store, NC & ALBE & 1993 & 2001 & 9 & .51 & 38 & 4 & Permeable soils and permeable bedrock \\
\hline 03015795 & East Hickory Creek near Queen, PA & ALMN & 1997 & 1998 & 2 & .47 & 45 & 9 & Impermeable soils and permeable bedrock \\
\hline 03037350 & South Branch Plum Creek at Five Points, PA & ALMN & 1997 & 1998 & 2 & .32 & 27 & 11 & Impermeable soils and impermeable bedrock \\
\hline 03040000 & Stonycreek River at Ferndale, PA & ALMN & 1996 & 1998 & 3 & .47 & 47 & 11 & Impermeable soils and impermeable bedrock \\
\hline 03049646 & Deer Creek near Dorseyville, PA & ALMN & 1997 & 1998 & 2 & .39 & 17 & 11 & Impermeable soils and impermeable bedrock \\
\hline 03072000 & Dunkard Creek at Shannopin, PA & ALMN & 1996 & 1998 & 3 & .30 & 25 & 11 & Impermeable soils and impermeable bedrock \\
\hline 09505800 & West Clear Creek near Camp Verde, AZ & CAZB & 2001 & 2005 & 5 & .61 & 23 & 11 & Impermeable soils and impermeable bedrock \\
\hline 12464770 & Crab Creek near Ritzville, WA & CCYK & 1994 & 2004 & 9 & .81 & 79 & 15 & Impermeable soils and permeable bedrock \\
\hline 06773050 & Prairie Creek near Ovina, NE & CNBR & 1994 & 1994 & 1 & .58 & 46 & 3 & Impermeable soils and permeable bedrock \\
\hline 06775900 & Dismal River near Thedford, NE & CNBR & 1990 & 2004 & 15 & .97 & 98 & 10 & Impermeable soils and permeable bedrock \\
\hline 06795500 & Shell Creek near Columbus, NE & CNBR & 1992 & 1995 & 4 & .40 & 47 & 9 & Impermeable soils and permeable bedrock \\
\hline 06800000 & Maple Creek near Nickerson, NE & CNBR & 1990 & 2005 & 16 & .45 & 58 & 11 & Impermeable soils and impermeable bedrock \\
\hline 01135300 & Sleepers River near St. Johnsbury, VT & CONN & 1993 & 1995 & 3 & .52 & 58 & 16 & Permeable soils and impermeable bedrock \\
\hline 01137500 & Ammonoosuc River at Bethlehem Junction, NH & CONN & 1993 & 1995 & 3 & .56 & 51 & 16 & Permeable soils and impermeable bedrock \\
\hline 01170100 & Green River near Colrain, MA & CONN & 1993 & 2005 & 13 & .48 & 37 & 16 & Permeable soils and impermeable bedrock \\
\hline 01199900 & Tenmile River near Wingdale, NY & CONN & 1993 & 1995 & 3 & .61 & 66 & 9 & Impermeable soils and permeable bedrock \\
\hline 01208873 & Rooster River at Fairfield, CT & CONN & 1993 & 1995 & 3 & .49 & 72 & 7 & Permeable soils and impermeable bedrock \\
\hline 01209710 & Norwalk River at Winnipauk,CT & CONN & 1990 & 2005 & 16 & .49 & 47 & 12 & Permeable soils and impermeable bedrock \\
\hline 01451800 & Jordon Creek near Schnecksville, PA & DELR & 1999 & 2001 & 3 & .43 & 47 & 9 & Impermeable soils and permeable bedrock \\
\hline 01464907 & Little Neshaminy Creek near Warminster, PA & DELR & 2000 & 2004 & 5 & .25 & 40 & 7 & Permeable soils and impermeable bedrock \\
\hline 01467150 & Cooper River at Haddonfield, $\mathrm{NJ}$ & DELR & 1999 & 2005 & 7 & .40 & 26 & 4 & Permeable soils and permeable bedrock \\
\hline 01470779 & Tulpehocken Creek near Bernville, PA & DELR & 1999 & 2001 & 3 & .73 & 78 & 9 & Impermeable soils and permeable bedrock \\
\hline 01472157 & French Creek near Phoenixville, PA & DELR & 1999 & 2005 & 7 & .54 & 58 & 16 & Permeable soils and impermeable bedrock \\
\hline 01477120 & Racoon Creek near Swedesboro, NJ & DELR & 1999 & 2005 & 7 & .63 & 75 & 2 & Permeable soils and permeable bedrock \\
\hline
\end{tabular}


[Water year, the continuous 12-month period, October 1 through September 3 . The water year is designated by the calendar year in which it ends and which includes 9 of the 12 months. Thus, the year ending September 30, 1980, is referred to as water year 1980.]

\begin{tabular}{|c|c|c|c|c|c|c|c|c|c|}
\hline $\begin{array}{l}\text { U.S. Geological } \\
\text { Survey site } \\
\text { number }\end{array}$ & Site name & $\begin{array}{c}\text { Study } \\
\text { unit } \\
\text { identifier }\end{array}$ & $\begin{array}{l}\text { First water } \\
\text { year of load } \\
\text { simulation }\end{array}$ & $\begin{array}{l}\text { Last water } \\
\text { year of load } \\
\text { simulation }\end{array}$ & $\begin{array}{l}\text { Number of } \\
\text { years of load } \\
\text { simulation }\end{array}$ & $\begin{array}{l}\text { Base- } \\
\text { flow } \\
\text { index }\end{array}$ & $\begin{array}{l}\text { Nitrate } \\
\text { load } \\
\text { ratio }\end{array}$ & $\begin{array}{c}\text { Dominant } \\
\text { hydrologic } \\
\text { landscape } \\
\text { region } \\
\text { (table 3) }\end{array}$ & $\begin{array}{l}\text { Hydrologic landscape } \\
\text { region category }\end{array}$ \\
\hline 02215100 & Tucsawhatchee Creek near Hawkinsville, GA & GAFL & 1993 & 1996 & 4 & 0.45 & 52 & 7 & Permeable soils and impermeable bedrock \\
\hline 02300700 & Bullfrog Creek near Wimauma, FL & GAFL & 1993 & 1996 & 4 & .33 & 34 & 1 & Permeable soils and permeable bedrock \\
\hline 02306774 & Rocky Creek near Citrus Park, FL & GAFL & 2002 & 2005 & 4 & .39 & 41 & 1 & Permeable soils and permeable bedrock \\
\hline 02317797 & Little River near Tifton, GA & GAFL & 1994 & 1997 & 4 & .29 & 33 & 2 & Permeable soils and permeable bedrock \\
\hline 10102200 & Cub River near Richmond, UT & GRSL & 1999 & 2000 & 2 & .73 & 87 & 15 & Impermeable soils and permeable bedrock \\
\hline 10167800 & Little Cottonwood Creek at Crestwood Park, UT & GRSL & 1999 & 2000 & 2 & .15 & 24 & 20 & Permeable soils and impermeable bedrock \\
\hline 10168000 & Little Cottonwood Creek at Salt Lake City, UT & GRSL & 1999 & 2005 & 7 & .32 & 44 & 20 & Permeable soils and impermeable bedrock \\
\hline 10172200 & Red Butte Creek at Fort Douglas, UT & GRSL & 1990 & 2005 & 16 & .89 & 58 & 20 & Permeable soils and impermeable bedrock \\
\hline 01356190 & Lisha Kill northwest of Niskayuna, NY & HDSN & 1994 & 2005 & 9 & .38 & 37 & 7 & Permeable soils and impermeable bedrock \\
\hline 01362200 & Esopus Creek at Allaben, NY & HDSN & 1993 & 2004 & 12 & .47 & 26 & 20 & Permeable soils and impermeable bedrock \\
\hline 01372051 & Fall Kill at Poughkeepsie, NY & HDSN & 1994 & 1995 & 2 & .53 & 44 & 7 & Permeable soils and impermeable bedrock \\
\hline 03167000 & Reed Creek at Grahams Forge, VA & KANA & 1997 & 1998 & 2 & .61 & 51 & 9 & Impermeable soils and permeable bedrock \\
\hline 03170000 & Little River at Graysontown, VA & KANA & 1997 & 1998 & 2 & .68 & 54 & 16 & Permeable soils and impermeable bedrock \\
\hline 03178000 & Bluestone River near Spanishburg, WV & KANA & 1997 & 1998 & 2 & .45 & 44 & 9 & Impermeable soils and permeable bedrock \\
\hline 03191500 & Peters Creek near Lockwood, WV & KANA & 1997 & 1998 & 2 & .42 & 37 & 16 & Permeable soils and impermeable bedrock \\
\hline 04159492 & Black River near Jeddo, MI & LERI & 1996 & 1998 & 3 & .27 & 27 & 6 & Impermeable soils and impermeable bedrock \\
\hline 04186500 & Auglaize River near Fort Jennings, $\mathrm{OH}$ & LERI & 1996 & 2005 & 10 & .17 & 12 & 3 & Impermeable soils and permeable bedrock \\
\hline 04213500 & Cattaraugus Creek at Gowanda, NY & LERI & 1990 & 1998 & 9 & .47 & 69 & 11 & Impermeable soils and impermeable bedrock \\
\hline 01390500 & Saddle River at Ridgewood, NJ & LINJ & 1996 & 1998 & 3 & .53 & 63 & 16 & Permeable soils and impermeable bedrock \\
\hline 01398000 & Neshanic River at Reaville, NJ & LINJ & 1991 & 2005 & 15 & .24 & 25 & 11 & Impermeable soils and impermeable bedrock \\
\hline 01403900 & Bound Brook at Middlesex, NJ & LINJ & 1997 & 1998 & 2 & .28 & 38 & 4 & Permeable soils and permeable bedrock \\
\hline 01410784 & Great Egg Harbor River near Sicklerville, NJ & LINJ & 1997 & 1998 & 2 & .58 & 88 & 2 & Permeable soils and permeable bedrock \\
\hline 05568800 & Indian Creek near Wyoming, IL & LIRB & 1997 & 1998 & 2 & .47 & 54 & 6 & Impermeable soils and impermeable bedrock \\
\hline 01555400 & East Mahantango Creek at Klingerstown, PA & LSUS & 1993 & 2000 & 6 & .36 & 32 & 9 & Impermeable soils and permeable bedrock \\
\hline 01559795 & Bobs Creek near Pavia, PA & LSUS & 1994 & 2000 & 4 & .41 & 41 & 9 & Impermeable soils and permeable bedrock \\
\hline 02398300 & Chattooga River above Gaylesville, AL & MOBL & 1999 & 2001 & 3 & .58 & 71 & 9 & Impermeable soils and permeable bedrock \\
\hline 02419977 & Three Mile Branch at Montgomery, AL & MOBL & 1999 & 2001 & 3 & .30 & 43 & 4 & Permeable soils and permeable bedrock \\
\hline 02421115 & Pintlalla Creek near Pintlalla, AL & MOBL & 1999 & 2001 & 3 & .16 & 15 & 4 & Permeable soils and permeable bedrock \\
\hline 0242354750 & Cahaba Valley Creek at Pelham, AL & MOBL & 1999 & 2005 & 7 & .40 & 65 & 9 & Impermeable soils and permeable bedrock \\
\hline 01095220 & Stillwater River near Sterling, MA & NECB & 1999 & 2004 & 6 & .49 & 63 & 16 & Permeable soils and impermeable bedrock \\
\hline 01101500 & Ipswich River at South Middleton, MA & NECB & 1999 & 2004 & 6 & .49 & 61 & 2 & Permeable soils and permeable bedrock \\
\hline 01102345 & Saugus River at Saugus, MA & NECB & 1999 & 2004 & 6 & .47 & 51 & 7 & Permeable soils and impermeable bedrock \\
\hline 01105000 & Neponset River at Norwood, MA & NECB & 1999 & 2004 & 6 & .53 & 62 & 7 & Permeable soils and impermeable bedrock \\
\hline 01109000 & Wading River near Norton, MA & NECB & 1999 & 2004 & 6 & .58 & 55 & 2 & Permeable soils and permeable bedrock \\
\hline 01112900 & Blackstone River at Manville, RI & NECB & 1993 & 2002 & 10 & .62 & 75 & 16 & Permeable soils and impermeable bedrock \\
\hline
\end{tabular}


Table 4. Nitrate load ratios and hydrologic landscape regions.-Continued

[Water year, the continuous 12-month period, October 1 through September 3. The water year is designated by the calendar year in which it ends and which includes 9 of the 12 months. Thus, the year ending September 30, 1980, is referred to as water year 1980.]

\begin{tabular}{|c|c|c|c|c|c|c|c|c|c|}
\hline $\begin{array}{l}\text { U.S. Geological } \\
\text { Survey site } \\
\text { number }\end{array}$ & Site name & $\begin{array}{c}\text { Study } \\
\text { unit } \\
\text { identifier }\end{array}$ & $\begin{array}{l}\text { First water } \\
\text { year of load } \\
\text { simulation }\end{array}$ & $\begin{array}{l}\text { Last water } \\
\text { year of load } \\
\text { simulation }\end{array}$ & $\begin{array}{l}\text { Number of } \\
\text { years of load } \\
\text { simulation }\end{array}$ & $\begin{array}{l}\text { Base- } \\
\text { flow } \\
\text { index }\end{array}$ & $\begin{array}{l}\text { Nitrate } \\
\text { load } \\
\text { ratio }\end{array}$ & $\begin{array}{c}\text { Dominant } \\
\text { hydrologic } \\
\text { landscape } \\
\text { region } \\
\text { (table 3) }\end{array}$ & $\begin{array}{l}\text { Hydrologic landscape } \\
\text { region category }\end{array}$ \\
\hline 12392155 & Lightning Creek at Clark Fork, ID & NROK & 1999 & 2001 & 3 & 0.60 & 37 & 19 & Permeable soils and impermeable bedrock \\
\hline 12413875 & St. Joe River near Red Ives Work Station, ID & NROK & 1999 & 2005 & 7 & .76 & 51 & 20 & Permeable soils and impermeable bedrock \\
\hline 06923150 & Dousinbury Creek near Wall Street, MO & OZRK & 1994 & 1997 & 4 & .26 & 12 & 9 & Impermeable soils and permeable bedrock \\
\hline 06929315 & Paddy Creek above Slabtown Spring, MO & OZRK & 1994 & 1997 & 4 & .21 & 13 & 9 & Impermeable soils and permeable bedrock \\
\hline 07053250 & Yocum Creek near Oak Grove, AR & OZRK & 1994 & 2005 & 12 & .43 & 39 & 9 & Impermeable soils and permeable bedrock \\
\hline 07055646 & Buffalo River near Boxley, AR & OZRK & 1994 & 2004 & 8 & .23 & 6 & 16 & Permeable soils and impermeable bedrock \\
\hline 07061600 & Black River Below Annapolis, MO & OZRK & 1993 & 2005 & 13 & .50 & 38 & 9 & Impermeable soils and permeable bedrock \\
\hline 07065495 & Jacks Fork River at Alley Spring, MO & OZRK & 1994 & 1997 & 4 & .48 & 43 & 9 & Impermeable soils and permeable bedrock \\
\hline 01485000 & Pocomoke River at Willards, MD & PODL & 1999 & 2002 & 4 & .55 & 45 & 1 & Permeable soils and permeable bedrock \\
\hline 01493112 & Chesterville Branch near Crumpton, MD & PODL & 1999 & 2002 & 4 & .70 & 83 & 4 & Permeable soils and permeable bedrock \\
\hline 01493500 & Morgan Creek near Kennedyville, MD & PODL & 1998 & 2004 & 7 & .52 & 67 & 4 & Permeable soils and permeable bedrock \\
\hline 01608000 & South Fork South Branch Potomac River near Moorefield, WV & PODL & 1993 & 1995 & 3 & .36 & 47 & 15 & Impermeable soils and permeable bedrock \\
\hline 01610400 & Waites Run near Wardensville, WV & PODL & 2003 & 2005 & 3 & .49 & 55 & 15 & Impermeable soils and permeable bedrock \\
\hline 01621050 & Muddy Creek at Mount Clinton, VA & PODL & 1994 & 2002 & 9 & .53 & 89 & 9 & Impermeable soils and permeable bedrock \\
\hline 01638480 & Catoctin Creek at Taylorstown, VA & PODL & 1993 & 1995 & 3 & .45 & 30 & 16 & Permeable soils and impermeable bedrock \\
\hline 01654000 & Accotink Creek near Annandale, VA & PODL & 1993 & 2002 & 10 & .22 & 29 & 7 & Permeable soils and impermeable bedrock \\
\hline 12056500 & North Fork Skokomish River near Hoodsport, WA & PUGT & 2001 & 2005 & 5 & .52 & 39 & 20 & Permeable soils and impermeable bedrock \\
\hline 12061500 & Skokomish River near Potlatch, WA & PUGT & 1996 & 1998 & 3 & .45 & 44 & 20 & Permeable soils and impermeable bedrock \\
\hline 12108500 & Newaukum Creek near Black Diamond, WA & PUGT & 1996 & 1998 & 3 & .57 & 60 & 3 & Impermeable soils and permeable bedrock \\
\hline 12112600 & Big Soos Creek near Auburn, WA & PUGT & 1996 & 1998 & 3 & .68 & 68 & 9 & Impermeable soils and permeable bedrock \\
\hline 12113375 & Springbrook Creek at Tukwila, WA & PUGT & 1996 & 1998 & 3 & .38 & 46 & 1 & Permeable soils and permeable bedrock \\
\hline 12113390 & Duwamish River at Tukwila, WA & PUGT & 1996 & 2004 & 9 & .64 & 62 & 19 & Permeable soils and impermeable bedrock \\
\hline 12128000 & Thornton Creek near Seattle, WA & PUGT & 1997 & 2005 & 9 & .61 & 71 & 9 & Impermeable soils and permeable bedrock \\
\hline 12212100 & Fishtrap Creek at Lynden, WA & PUGT & 1997 & 1998 & 2 & .60 & 62 & 1 & Permeable soils and permeable bedrock \\
\hline 05082625 & Turtle River near Arvilla, ND & REDN & 1993 & 2000 & 8 & .36 & 9 & 8 & Impermeable soils and impermeable bedrock \\
\hline 11447360 & Arcade Creek near Del Paso Heights, CA & SACR & 1997 & 2005 & 9 & .08 & 3 & 10 & Impermeable soils and permeable bedrock \\
\hline 11274538 & Orestimba Creek near Crows Landing, CA & SANJ & 1993 & 2005 & 13 & .29 & 46 & 5 & Permeable soils and permeable bedrock \\
\hline 021603257 & Brushy Creek near Pelham, SC & SANT & 1996 & 1997 & 2 & .55 & 64 & 16 & Permeable soils and impermeable bedrock \\
\hline 021607224 & Indian Creek Above Newberry, SC & SANT & 1996 & 1998 & 3 & .35 & 32 & 7 & Permeable soils and impermeable bedrock \\
\hline 02174250 & Cow Castle Creek near Bowman, SC & SANT & 1996 & 2005 & 10 & .46 & 46 & 1 & Permeable soils and permeable bedrock \\
\hline 08169000 & Comal River at New Braunfels, TX & SCTX & 1996 & 1998 & 3 & .98 & 98 & 10 & Impermeable soils and permeable bedrock \\
\hline 08171000 & Blanco River at Wimberley, TX & SCTX & 1996 & 1998 & 3 & .62 & 56 & 10 & Impermeable soils and permeable bedrock \\
\hline 08178800 & Salado Creek at San Antonio, TX & SCTX & 1990 & 2005 & 16 & .24 & 32 & 15 & Impermeable soils and permeable bedrock \\
\hline 08195000 & Frio River at Concan, TX & SCTX & 1993 & 2004 & 12 & .69 & 72 & 15 & Impermeable soils and permeable bedrock \\
\hline 11060400 & Warm Creek near San Bernardino, CA & SOCA & 1999 & 2004 & 6 & .27 & 14 & 14 & Permeable soils and permeable bedrock \\
\hline
\end{tabular}


[Water year, the continuous 12-month period, October 1 through September 3. The water year is designated by the calendar year in which it ends and which includes 9 of the 12 months. Thus, the year ending September 30, 1980, is referred to as water year 1980.]

\begin{tabular}{|c|c|c|c|c|c|c|c|c|c|}
\hline $\begin{array}{l}\text { U.S. Geological } \\
\text { Survey site } \\
\text { number }\end{array}$ & Site name & $\begin{array}{c}\text { Study } \\
\text { unit } \\
\text { identifier }\end{array}$ & $\begin{array}{c}\text { First water } \\
\text { year of load } \\
\text { simulation }\end{array}$ & $\begin{array}{l}\text { Last water } \\
\text { year of load } \\
\text { simulation }\end{array}$ & $\begin{array}{l}\text { Number of } \\
\text { years of load } \\
\text { simulation }\end{array}$ & $\begin{array}{l}\text { Base- } \\
\text { flow } \\
\text { index }\end{array}$ & $\begin{array}{l}\text { Nitrate } \\
\text { load } \\
\text { ratio }\end{array}$ & $\begin{array}{c}\text { Dominant } \\
\text { hydrologic } \\
\text { landscape } \\
\text { region } \\
\text { (table 3) }\end{array}$ & $\begin{array}{l}\text { Hydrologic landscape } \\
\text { region category }\end{array}$ \\
\hline 11073495 & Cucamonga Creek near Mira Loma, CA & SOCA & 1999 & 2001 & 3 & 0.69 & 53 & 14 & Permeable soils and permeable bedrock \\
\hline 06753400 & Lonetree Creek at Carr, CO & SPLT & 1994 & 1995 & 2 & .77 & 86 & 10 & Impermeable soils and permeable bedrock \\
\hline 402114105350101 & Big Thompson River near Estes Park, CO & SPLT & 1996 & 2004 & 5 & .69 & 64 & 20 & Permeable soils and impermeable bedrock \\
\hline 03466208 & Big Limestone Creek near Limestone, TN & TENN & 1997 & 2004 & 7 & .72 & 73 & 9 & Impermeable soils and permeable bedrock \\
\hline 03524550 & Guest River near Miller Yard, VA & TENN & 1997 & 1998 & 2 & .42 & 41 & 16 & Permeable soils and impermeable bedrock \\
\hline 03526000 & Copper Creek near Gate City, VA & TENN & 1997 & 1998 & 2 & .50 & 52 & 9 & Impermeable soils and permeable bedrock \\
\hline 03573182 & Scarham Creek near McVille, AL & TENN & 1999 & 2001 & 3 & .35 & 43 & 7 & Permeable soils and impermeable bedrock \\
\hline 0357479650 & Hester Creek near Plevna, AL & TENN & 1999 & 2004 & 6 & .25 & 29 & 4 & Permeable soils and permeable bedrock \\
\hline 03575100 & Flint River near Brownsboro, AL & TENN & 1999 & 2004 & 6 & .41 & 57 & 7 & Permeable soils and impermeable bedrock \\
\hline 035825882 & Cane Creek near Howell, TN & TENN & 1999 & 2001 & 3 & .20 & 12 & 9 & Impermeable soils and permeable bedrock \\
\hline 03598250 & North Fork Creek near Poplins Crossroads, TN & TENN & 1999 & 2001 & 3 & .19 & 13 & 3 & Impermeable soils and permeable bedrock \\
\hline 08044000 & Big Sandy Creek near Bridgeport, TX & TRIN & 1993 & 1995 & 3 & .23 & 6 & 10 & Impermeable soils and permeable bedrock \\
\hline 08051500 & Clear Creek near Sanger, TX & TRIN & 1993 & 2005 & 13 & .24 & 3 & 8 & Impermeable soils and impermeable bedrock \\
\hline 08057200 & White Rock Creek at Dallas, TX & TRIN & 1995 & 2005 & 11 & .26 & 28 & 8 & Impermeable soils and impermeable bedrock \\
\hline 08058900 & East Fork Trinity River at McKinney, TX & TRIN & 1993 & 1995 & 3 & .21 & 13 & 8 & Impermeable soils and impermeable bedrock \\
\hline 08065800 & Bedias Creek near Madisonville, TX & TRIN & 1993 & 1995 & 3 & .04 & 24 & 4 & Permeable soils and permeable bedrock \\
\hline 08066295 & Menard Creek near Fuqua, TX & TRIN & 1993 & 1995 & 3 & .35 & 65 & 4 & Permeable soils and permeable bedrock \\
\hline 09010500 & Colorado River near Grand Lake, CO & UCOL & 1995 & 1998 & 4 & .65 & 39 & 20 & Permeable soils and impermeable bedrock \\
\hline 09046530 & French Gulch at Breckenridge, $\mathrm{CO}$ & UCOL & 1996 & 1999 & 4 & .74 & 74 & 18 & Permeable soils and impermeable bedrock \\
\hline 05531500 & Salt Creek at Western Springs, IL & UIRB & 1999 & 2006 & 8 & .46 & 81 & 3 & Impermeable soils and permeable bedrock \\
\hline 05548105 & Nippersink Creek above Wonder Lake, IL & UIRB & 1999 & 2001 & 3 & .51 & 44 & 6 & Impermeable soils and impermeable bedrock \\
\hline 05276005 & North Fork Crow River above Paynesville, MN & UMIS & 1997 & 1998 & 2 & .39 & 32 & 1 & Permeable soils and permeable bedrock \\
\hline 05288705 & Shingle Creek at Minneapolis, MN & UMIS & 1997 & 2005 & 6 & .37 & 43 & 7 & Permeable soils and impermeable bedrock \\
\hline 05320270 & Little Cobb River near Beauford, MN & UMIS & 1997 & 2005 & 7 & .37 & 31 & 6 & Impermeable soils and impermeable bedrock \\
\hline 05330902 & Nine Mile Creek at Bloomington, MN & UMIS & 1997 & 1998 & 2 & .31 & 48 & 7 & Permeable soils and impermeable bedrock \\
\hline 13092747 & Rock Creek at Twin Falls, ID & USNK & 1993 & 2005 & 13 & .88 & 97 & 15 & Impermeable soils and permeable bedrock \\
\hline 13120500 & Big Lost River near Chilly, ID & USNK & 1993 & 1996 & 4 & .74 & 55 & 20 & Permeable soils and impermeable bedrock \\
\hline 03267900 & Mad River near Eagle City, OH & WHMI & 1999 & 2005 & 7 & .67 & 63 & 3 & Impermeable soils and permeable bedrock \\
\hline 03353637 & Little Buck Creek near Indianapolis, IN & WHMI & 1990 & 2004 & 15 & .22 & 20 & 6 & Impermeable soils and impermeable bedrock \\
\hline 03360895 & Kessinger Ditch near Monroe City, IN & WHMI & 1993 & 1995 & 3 & .18 & 29 & 11 & Impermeable soils and impermeable bedrock \\
\hline 03366500 & Muscatatuck River near Deputy, IN & WHMI & 1993 & 1995 & 3 & .18 & 23 & 9 & Impermeable soils and permeable bedrock \\
\hline 03373530 & Lost River near Leipsic, IN & WHMI & 1993 & 1995 & 3 & .31 & 43 & 9 & Impermeable soils and permeable bedrock \\
\hline 391732085414401 & Clifty Creek near Hartsville, IN & WHMI & 1993 & 1995 & 3 & .29 & 30 & 3 & Impermeable soils and permeable bedrock \\
\hline 393944084120700 & Holes Creek at Kettering, OH & WHMI & 2000 & 2004 & 5 & .19 & 24 & 7 & Permeable soils and impermeable bedrock \\
\hline 394340085524601 & Sugar Creek at New Palestine, IN & WHMI & 1992 & 2005 & 14 & .32 & 21 & 6 & Impermeable soils and impermeable bedrock \\
\hline
\end{tabular}


Table 4. Nitrate load ratios and hydrologic landscape regions.-Continued

[Water year, the continuous 12-month period, October 1 through September 3 . The water year is designated by the calendar year in which it ends and which includes 9 of the 12 months. Thus, the year ending September 30, 1980, is referred to as water year 1980.]

\begin{tabular}{|c|c|c|c|c|c|c|c|c|c|}
\hline $\begin{array}{l}\text { U.S. Geological } \\
\text { Survey site } \\
\text { number }\end{array}$ & Site name & $\begin{array}{l}\text { Study } \\
\text { unit } \\
\text { identifier }\end{array}$ & $\begin{array}{c}\text { First water } \\
\text { year of load } \\
\text { simulation }\end{array}$ & $\begin{array}{c}\text { Last water } \\
\text { year of load } \\
\text { simulation }\end{array}$ & $\begin{array}{l}\text { Number of } \\
\text { years of load } \\
\text { simulation }\end{array}$ & $\begin{array}{l}\text { Base- } \\
\text { flow } \\
\text { index }\end{array}$ & $\begin{array}{l}\text { Nitrate } \\
\text { load } \\
\text { ratio }\end{array}$ & $\begin{array}{c}\text { Dominant } \\
\text { hydrologic } \\
\text { landscape } \\
\text { region } \\
\text { (table 3) }\end{array}$ & $\begin{array}{l}\text { Hydrologic landscape } \\
\text { region category }\end{array}$ \\
\hline 14200400 & Little Abiqua Creek near Scotts Mills, OR & WILL & 1994 & 2004 & 11 & 0.51 & 39 & 19 & Permeable soils and impermeable bedrock \\
\hline 14201300 & Zollner Creek near Mt. Angel, OR & WILL & 1994 & 2005 & 12 & .31 & 25 & 3 & Impermeable soils and permeable bedrock \\
\hline 14205400 & East Fork Dairy Creek near Meachan Corner, OR & WILL & 2003 & 2005 & 3 & .63 & 43 & 19 & Permeable soils and impermeable bedrock \\
\hline 14206950 & Fanno Creek at Durham, OR & WILL & 1994 & 2005 & 7 & .32 & 32 & 9 & Impermeable soils and permeable bedrock \\
\hline 04063700 & Popple River near Fence, WI & WMIC & 1990 & 2005 & 16 & .61 & 59 & 2 & Permeable soils and permeable bedrock \\
\hline 04072050 & Duck Creek near Howard, WI & WMIC & 1993 & 2005 & 13 & .23 & 19 & 6 & Impermeable soils and impermeable bedrock \\
\hline 040869415 & Lincoln Creek at Milwaukee, WI & WMIC & 1994 & 1994 & 1 & .27 & 10 & 3 & Impermeable soils and permeable bedrock \\
\hline 06187915 & Soda Butte Creek near Silvergate, MT & YELL & 1999 & 2001 & 3 & .68 & 53 & 20 & Permeable soils and impermeable bedrock \\
\hline 06298000 & Tongue River near Dayton, WY & YELL & 1999 & 2002 & 4 & .65 & 58 & 16 & Permeable soils and impermeable bedrock \\
\hline
\end{tabular}


Table 5. Base-flow nitrate concentrations.

[Ag, Agriculture; Undev, undeveloped]

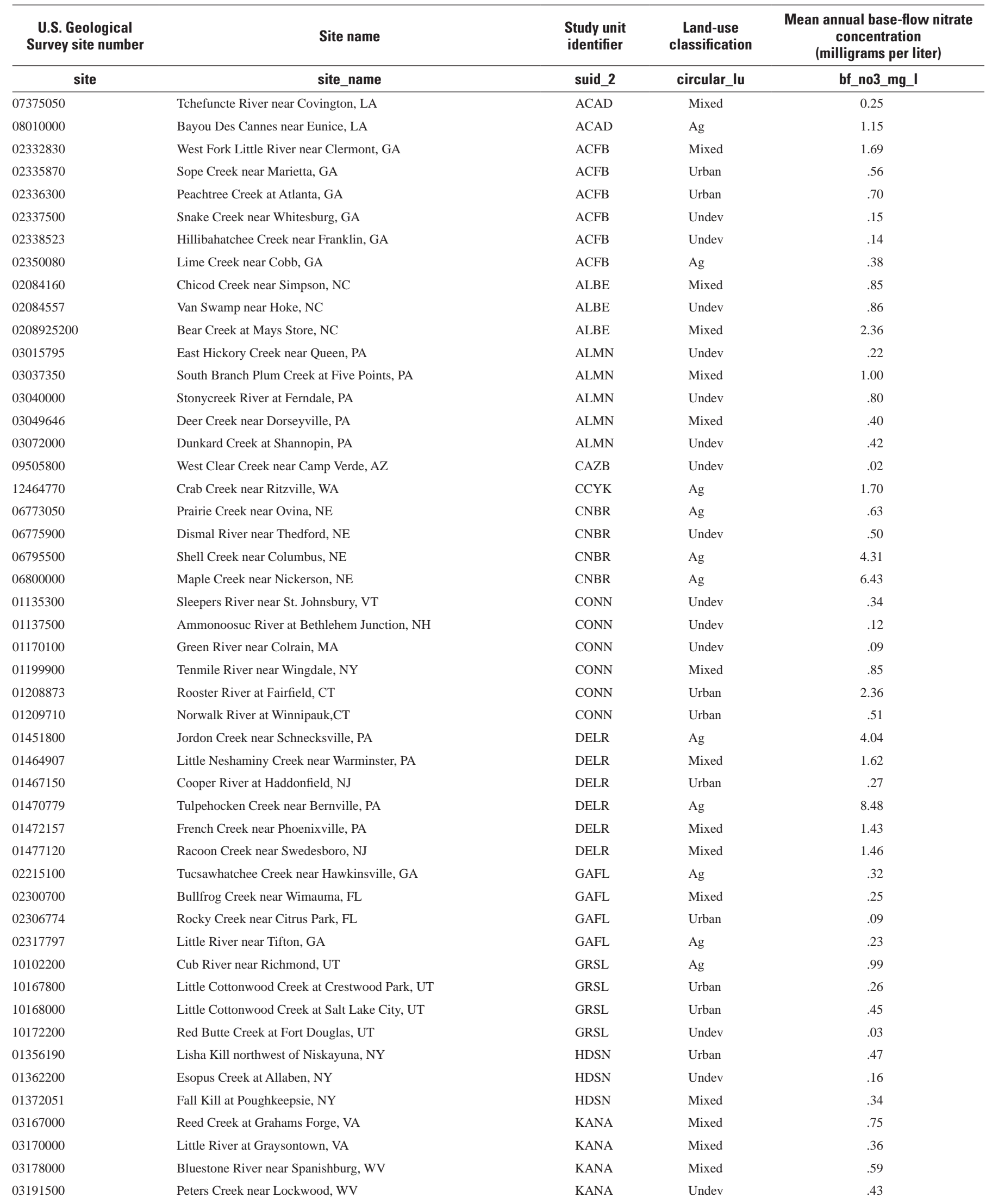


Table 5. Base-flow nitrate concentrations.-Continued

[Ag, Agriculture; Undev, undeveloped]

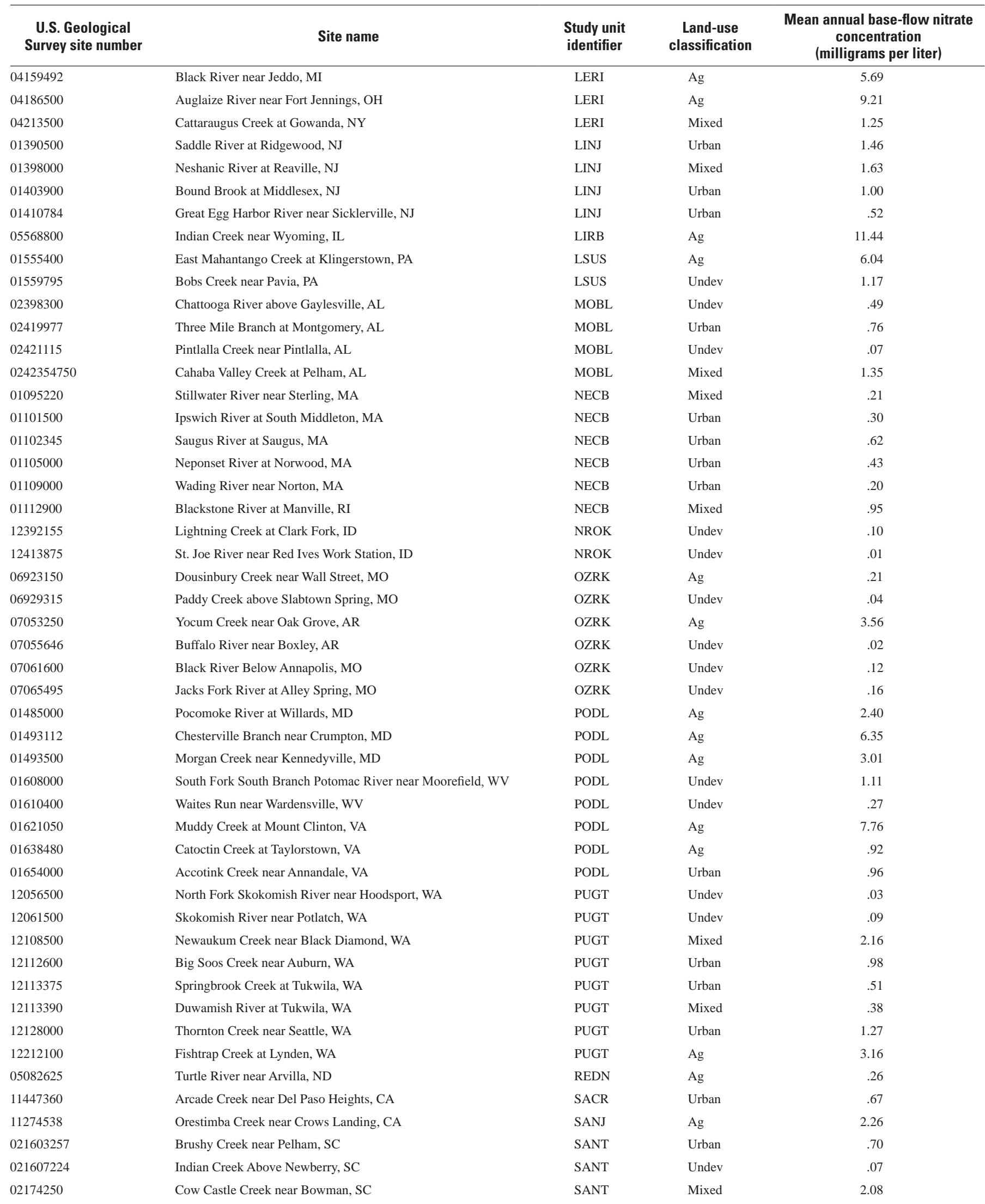


Table 5. Base-flow nitrate concentrations.-Continued

[Ag, Agriculture; Undev, undeveloped]

\begin{tabular}{|c|c|c|c|c|}
\hline $\begin{array}{l}\text { U.S. Geological } \\
\text { Survey site number }\end{array}$ & Site name & $\begin{array}{l}\text { Study unit } \\
\text { identifier }\end{array}$ & $\begin{array}{l}\text { Land-use } \\
\text { classification }\end{array}$ & $\begin{array}{c}\text { Mean annual base-flow nitrate } \\
\text { concentration } \\
\text { (milligrams per liter) }\end{array}$ \\
\hline 08169000 & Comal River at New Braunfels, TX & SCTX & Mixed & 1.69 \\
\hline 08178800 & Salado Creek at San Antonio, TX & SCTX & Urban & 1.31 \\
\hline 08195000 & Frio River at Concan, TX & SCTX & Undev & .72 \\
\hline 11060400 & Warm Creek near San Bernardino, CA & SOCA & Urban & .38 \\
\hline 06753400 & Lonetree Creek at Carr, CO & SPLT & Undev & .23 \\
\hline 402114105350101 & Big Thompson River near Estes Park, CO & SPLT & Undev & .11 \\
\hline 03466208 & Big Limestone Creek near Limestone, TN & TENN & $\mathrm{Ag}$ & 2.03 \\
\hline 03524550 & Guest River near Miller Yard, VA & TENN & Mixed & .47 \\
\hline 03526000 & Copper Creek near Gate City, VA & TENN & Mixed & 1.26 \\
\hline 03598250 & North Fork Creek near Poplins Crossroads, TN & TENN & $\mathrm{Ag}$ & .86 \\
\hline 08044000 & Big Sandy Creek near Bridgeport, TX & TRIN & Mixed & .06 \\
\hline 08051500 & Clear Creek near Sanger, TX & TRIN & Mixed & .26 \\
\hline 08057200 & White Rock Creek at Dallas, TX & TRIN & Mixed & 2.04 \\
\hline 08058900 & East Fork Trinity River at McKinney, TX & TRIN & $\mathrm{Ag}$ & .99 \\
\hline 08065800 & Bedias Creek near Madisonville, TX & TRIN & $\mathrm{Ag}$ & .86 \\
\hline 08066295 & Menard Creek near Fuqua, TX & TRIN & Undev & .10 \\
\hline 09010500 & Colorado River near Grand Lake, CO & UCOL & Undev & .04 \\
\hline 09046530 & French Gulch at Breckenridge, CO & UCOL & Mixed & .09 \\
\hline 05531500 & Salt Creek at Western Springs, IL & UIRB & Urban & 8.29 \\
\hline 03267900 & Mad River near Eagle City, OH & WHMI & $\mathrm{Ag}$ & 4.03 \\
\hline 03353637 & Little Buck Creek near Indianapolis, IN & WHMI & Mixed & .82 \\
\hline 03360895 & Kessinger Ditch near Monroe City, IN & WHMI & $\mathrm{Ag}$ & 4.98 \\
\hline 03366500 & Muscatatuck River near Deputy, IN & WHMI & $\mathrm{Ag}$ & 1.50 \\
\hline 03373530 & Lost River near Leipsic, IN & WHMI & $\mathrm{Ag}$ & 7.49 \\
\hline 391732085414401 & Clifty Creek near Hartsville, IN & WHMI & $\mathrm{Ag}$ & 8.25 \\
\hline 393944084120700 & Holes Creek at Kettering, $\mathrm{OH}$ & WHMI & Mixed & 1.15 \\
\hline 394340085524601 & Sugar Creek at New Palestine, IN & WHMI & $\mathrm{Ag}$ & 2.73 \\
\hline 14200400 & Little Abiqua Creek near Scotts Mills, OR & WILL & Undev & .39 \\
\hline 14201300 & Zollner Creek near Mt. Angel, OR & WILL & $\mathrm{Ag}$ & 1.95 \\
\hline 14205400 & East Fork Dairy Creek near Meachan Corner, OR & WILL & Undev & .50 \\
\hline 14206950 & Fanno Creek at Durham, OR & WILL & Urban & .85 \\
\hline 04063700 & Popple River near Fence, WI & WMIC & Undev & .08 \\
\hline 04072050 & Duck Creek near Howard, WI & WMIC & $\mathrm{Ag}$ & 3.62 \\
\hline 040869415 & Lincoln Creek at Milwaukee, WI & WMIC & Urban & .35 \\
\hline 06187915 & Soda Butte Creek near Silvergate, MT & YELL & Undev & .04 \\
\hline 06298000 & Tongue River near Dayton, WY & YELL & Undev & .07 \\
\hline
\end{tabular}


Table 6. Base-flow nitrate concentration and associated land-use study network median nitrate concentration.

\begin{tabular}{|c|c|c|c|c|c|c|c|c|}
\hline $\begin{array}{l}\text { U.S. Geological } \\
\text { Survey site } \\
\text { number }\end{array}$ & Site name & $\begin{array}{l}\text { Study unit } \\
\text { identifier }\end{array}$ & $\begin{array}{l}\text { Drainage area } \\
\text { (square kilometers) }\end{array}$ & Hydrologic landscape category & $\begin{array}{l}\text { Median nitrate } \\
\text { concentration for } \\
\text { land-use study } \\
\text { well network } \\
\text { (milligrams per liter) }\end{array}$ & $\begin{array}{c}\text { Mean annual } \\
\text { base-flow nitrate } \\
\text { concentration } \\
\text { (milligrams per liter) }\end{array}$ & $\begin{array}{l}\text { Nitrate } \\
\text { load ratio }\end{array}$ & $\begin{array}{l}\text { Base- } \\
\text { flow } \\
\text { index }\end{array}$ \\
\hline site & site_name & suid & drain_area_sqkm & hlr_category & gw_net_median & bf_no3_mg_I & load_ratio & bfi_sim \\
\hline 01109000 & Wading River near Norton, MA & NECB & 113 & Permeable soils and permeable bedrock & 1.09 & 0.20 & 55 & 0.58 \\
\hline 01199900 & Tenmile River near Wingdale, NY & CONN & 499 & Impermeable soils and permeable bedrock & 3.70 & .85 & 66 & .61 \\
\hline 01356190 & Lisha Kill northwest of Niskayuna, NY & HDSN & 40 & Permeable soils and impermeable bedrock & .39 & .47 & 37 & .38 \\
\hline 01410784 & Great Egg Harbor River near Sicklerville, NJ & LINJ & 39 & Permeable soils and permeable bedrock & 2.65 & .52 & 88 & .58 \\
\hline 01470779 & Tulpehocken Creek near Bernville, PA & DELR & 179 & Impermeable soils and permeable bedrock & 8.55 & 8.48 & 78 & .73 \\
\hline 01477120 & Racoon Creek near Swedesboro, NJ & DELR & 67 & Permeable soils and permeable bedrock & 13.00 & 1.46 & 75 & .63 \\
\hline 01485000 & Pocomoke River at Willards, MD & PODL & 138 & Permeable soils and permeable bedrock & 5.41 & 2.40 & 45 & .55 \\
\hline 01493500 & Morgan Creek near Kennedyville, MD & PODL & 33 & Permeable soils and permeable bedrock & 5.41 & 3.01 & 67 & .52 \\
\hline 01608000 & South Fork South Branch Potomac River near Moorefield, WV & PODL & 718 & Impermeable soils and permeable bedrock & .05 & 1.11 & 47 & .36 \\
\hline 02317797 & Little River near Tifton, GA & GAFL & 335 & Permeable soils and permeable bedrock & 6.70 & .23 & 33 & .29 \\
\hline 02335870 & Sope Creek near Marietta, GA & ACFB & 80 & Permeable soils and impermeable bedrock & 1.60 & .56 & 41 & .37 \\
\hline 02336300 & Peachtree Creek at Atlanta, GA & ACFB & 222 & Permeable soils and impermeable bedrock & 1.60 & .70 & 33 & .27 \\
\hline 02350080 & Lime Creek near Cobb, GA & ACFB & 162 & Permeable soils and permeable bedrock & 1.40 & .38 & 39 & .48 \\
\hline 02419977 & Three Mile Branch at Montgomery, AL & MOBL & 23 & Permeable soils and permeable bedrock & 1.51 & .76 & 43 & .30 \\
\hline 03267900 & Mad River near Eagle City, OH & WHMI & 802 & Impermeable soils and permeable bedrock & 5.89 & 4.03 & 63 & .67 \\
\hline 03360895 & Kessinger Ditch near Monroe City, IN & WHMI & 146 & Impermeable soils and impermeable bedrock & .31 & 4.98 & 29 & .18 \\
\hline 0357479650 & Hester Creek near Plevna, AL & TENN & 76 & Permeable soils and permeable bedrock & .94 & 1.22 & 29 & .25 \\
\hline 03575100 & Flint River near Brownsboro, AL & TENN & 969 & Permeable soils and impermeable bedrock & .94 & 1.53 & 57 & .41 \\
\hline 04159492 & Black River near Jeddo, MI & LERI & 1198 & Impermeable soils and impermeable bedrock & .17 & 5.69 & 27 & .27 \\
\hline 05288705 & Shingle Creek at Minneapolis, MN & UMIS & 73 & Permeable soils and impermeable bedrock & 1.45 & .44 & 43 & .37 \\
\hline 05548105 & Nippersink Creek above Wonder Lake, IL & UIRB & 219 & Impermeable soils and impermeable bedrock & .39 & 4.22 & 44 & .51 \\
\hline 08010000 & Bayou Des Cannes near Eunice, LA & ACAD & 369 & Impermeable soils and impermeable bedrock & .05 & 1.15 & 30 & .07 \\
\hline 08178800 & Salado Creek at San Antonio, TX & SCTX & 506 & Impermeable soils and permeable bedrock & 1.46 & 1.31 & 32 & .24 \\
\hline 10167800 & Little Cottonwood Creek at Crestwood Park, UT & GRSL & 94 & Permeable soils and impermeable bedrock & 6.83 & .26 & 24 & .15 \\
\hline 10168000 & Little Cottonwood Creek at Salt Lake City, UT & GRSL & 117 & Permeable soils and impermeable bedrock & 6.83 & .45 & 44 & .32 \\
\hline 11447360 & Arcade Creek near Del Paso Heights, CA & SACR & 82 & Impermeable soils and permeable bedrock & 2.42 & .67 & 3 & .08 \\
\hline 12212100 & Fishtrap Creek at Lynden, WA & PUGT & 99 & Permeable soils and permeable bedrock & 12.87 & 3.16 & 62 & .60 \\
\hline
\end{tabular}


Publishing support provided by:

Denver Publishing Service Center

For more information concerning this publication, contact: Director, USGS Colorado Water Science Center

Box 25046, Mail Stop 415

Denver, CO 80225

(303) 236-4882

Or visit the Colorado Water Science Center Web site at: http://co.water.usgs.gov/ 
章

ISBN 978-141132859-4 